\title{
JOURNAL OF RESEARCHES
}

INTO THE

\section{NATURAL HISTORY AND GEOLOGY}

OF THE

COUNTRIES VISITED DURING THE VOYAGE OF H.M.S. BEAGLE ROUND THE WORLD,

UNDER THF

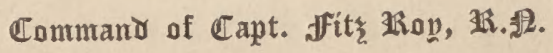

By CHARLES DARWIN, M.A., F.R.S.

SECOND EDITION, CORRECTED, WITH ADDITIONS.

\section{LONDON :}

JOHN MURRAY, ALBEMARLE STREET. 


\section{CHA R ES L Y E L L, EsQ., F.R.S.,}

THIS SECOND EDITION IS DEDICATED WITH GRATEFUL PLEASURE, AS AN ACKNOWLEDGMENT THAT THE CHIEF PART OF WHATEVER SCIENTIFIC MERIT THIS JOURNAL AND THE OTHER WORKS OF THE AUTHOR MAY POSSESS, HAS BEEN DERIVED FROM STUDYING THE WELL-KNOWN AND ADMIRABLE

PRINCIPLES OF GEOLOGY. 


\section{( v ) \\ P R E F A C E.}

I HAVE stated in the preface to the first Edition of this work, and in the Zoology of the Voyage of the Beagle, that it was in consequence of a wish expressed by Captain Fitz Roy, of having some scientific person on board, accompanied by an offer from him of giving up part of his own accommodations, that I volunteered my services, which received, through the kindness of the hydrographer, Captain Beaufort, the sanction of the Lords of the Admiralty. As I feel that the opportunities which I enjoyed of studying the Natural History of the different countries we visited, have been wholly due to Captain Fitz Roy, I hope I may here be permitted to repeat my expression of gratitude to him ; and to add that, during the five years we were together, I received from him the most cordial friendship and steady assistance. Both to Captain Fitz Roy and to all the Officers of the Beagle * I shall ever feel most thankful for the undeviating kindness with which I was treated during our long voyage.

This volume contains, in the form of a Journal, a history of our voyage, and a sketch of those observations in Natural History and Geology, which I think will possess some interest for the general reader. I have in this edition largely condensed and corrected some parts, and have added a little to others, in order to render the volume more fitted for popular reading; but I trust that naturalists will remember, that they must refer for details to the larger publications, which comprise the scientific results of the Expedition. The Zoology of the Voyage of the Beagle-includes an account of the Fossil Mammalia, by Professor Owen; of the Living Mammalia, by Mr. Waterhouse; of the Birds, by Mr. Gould; of the Fish, by the Rev. L. Jenyns; and of the Reptiles, by Mr. Bell. I have appended to the descriptions of each species an account of its habits and range. These works, which I owe to the high

* I must take this opportunity of returning my sincere thanks to Mr. Bynoe, the surgeon of the Beagle, for his very kind attention to me when I was ill at Valparaiso. 
talents and disinterested zeal of the above distinguished authors, could not have been undertaken, had it not been for the liberality of the Lords Commissioners of Her Majesty's Treasury, who, through the representation of the Right Honourable the Chancellor of the Exchequer, have been pleased to grant a sum of one thousand pounds towards defraying part of the expenses of publication.

I have myself published separate volumes on the 'Structure and Distribution of Coral Reefs;' on the 'Volcanic Islands visited during the Voyage of the Beagle;' and a third volume will soon appear on the 'Geology of South America.' The sixth volume of the 'Geological Transactions' contains two papers of mine on the Erratic Boulders and Volcanic Phenomena of South America. I intend hereafter to describe, in a set of papers, some of the marine invertebrate animals collected during the voyage. Mr. Bell, I hope, will describe the crustacea, and Mr. Sowerby the shells. Messrs. Waterhouse, Walker, Newman, and White, have published several able papers on the Insects which were collected, and I trust that many others will hereafter follow. The plants from the southern parts of America will be given by Dr. J. Hooker, in his great work on the Botany of the Southern Hemisphere. The Flora of the Galapagos Archipelago is the subject of a separate memoir by him, in the 'Linnean Transactions.' The Reverend Professor Henslow has published a list of the plants collected by me at the Keeling Islands; and the Reverend J. M. Berkeley has described my cryptogamic plants.

I shall have the pleasure of acknowledging the great assistance which I have received from several other naturalists, in the course of this and my other works; but I must be here allowed to return my most sincere thanks to the Reverend Professor Henslow, who, when I was an under-graduate at Cambridge, was one chief means of giving me a taste for Natural History, -who, during my absence, took charge of the collections I sent home, and by his correspondence directed my endeavours, - and who, since my return, has constantly rendered me every assist-
ance which the kindest friend could offer.

June, 1845. 


\section{( vii ) \\ CONTENTS OF PART I.}

\section{CHAPTER I.}

Porto Praya-Ribeira Grande-Atmospheric Dust with Infusoria-

Habits of a Sea-slug and Cuttle-fish-St. Paul's Rocks, non-volcanic - Singular Incrustations - Insects the first Colonists of IslandsFernando Noronha-Bahia-Burnished Rocks-Habits of a Diodon -Pelagic Confervæ and Infusoria-Causes of discoloured Sea .

\section{CHAPTER II.}

Rio de Janeiro-Excursion north of Cape Frio-Great EvaporationSlavery-Botofogo Bay-Terrestrial Planariæ-Clouds on the Corcovado-Heavy Rain-Musical Frogs-Phosphorescent InsectsElater, springing powers of-Blue Haze-Noise made by a Butterfly -Entomology-Ants-Wasp killing a Spider-Parasitical SpiderArtifices of an Epeira-Gregarious Spider-Spider with an unsymmetrical Web

\section{CHAPTER III.}

Monte Video--Maldonado-Excursion to R. Polanco-Lazo and Bolas -Partridges-Absence of Trees-Deer-Capybara, or River HogTucutuco-Molothrus, cuckoo-like habits - Tyrant FlycatcherMocking-bird - Carrion Hawks - Tubes formed by Lightning House struck . . . . . . . . . .

\section{CHAPTER IV.}

Rio Negro-Estancias attacked by the Indians-Salt Lakes-Flamingoes-R. Negro to Colorado-Sacred Tree-Patagonian HareIndian Families-General Rosas-Proceed to Bahia Blanca-Sand Dunes-Negro Lieutenant-Bahia Blanca-Saline IncrustationsPunta Alta-Zorillo 


\section{CHAPTER V.}

Bahia Blanca-Geology-Numerous gigantic extinct QuadrupedsRecent Extinction-Longevity of Species-Large Animals do not require a luxuriant Vegetation-Southern Africa-Siberian FossilsTwo Species of Ostrich, habits of-Oven-bird-Armadillos-Venomous Snake, Toad, Lizard-Hybernation of Animals-Habits of Sea-Pen - Indian Wars and Massacres-Arrow-head, Antiquarian Reli

\section{CHAPTER VI.}

Set out for Buenos Ayres-Rio Sauce- Sierra Ventana-Third Posta-

Driving Horses-Bolas-Partridges and Foxes-Features of Country -Long-legged Plover-Teru-tero-Hailstorm-Natural Enclosures in the Sierra Tapalguen-Flesh of Puma-Meat Diet-Guardia del Monte-Effects of Cattle on the Vegetation - Cardoon-Buenos Ayres-Corral where Cattle are slaughtered

\section{CHAPTER VII.}

Excursion to St. Fé-Thistle-Beds-Habits of the Bizcacha-Little Owl-Saline Streams-Level Plains-Mastodon-St. Fé-Change in Landscape-Geology-Tooth of extinct Horse-Relation of the Fossil and recent Quadrupeds of North and South America-Effects of a great Dronght-Parana-Habits of the Jaguar-Scissor-beak-Kingfisher, Parrot, and Scissor-tail-Revolution-Buenos Ayres-State of Government . • . . . . . .

\section{CHAPTER VIII.}

Excursion to Colonia del Sacramiento-Value of an Estancia-Cattle, how counted - Singular Breed of Oxen - Perforated Pebbles Shepherd-Dogs-Horses broken-in, Gauchos Riding-Character of Inhabitants-Rio Plata-Flocks of Butterflies-Aëronaut SpidersPhosphorescence of the Sea-Port Desire-Guanaco-Port St. Julian -Geology of Patagonia-Fossil gigantic Animal-Types of Organization constant-Change in the Zoology of America-Causes of Fxtinction 
place in the island: it now presents a melancholy, but very picturesque appearance. Having procured a black Padre for a guide, and a Spaniard who had served in the Peninsular war as an interpreter, we visited a collection of buildings, of which an ancient church formed the principal part. It is here the governors and captain-generals of the islands have been buried. Some of the tombstones recorded dates of the sixteenth century.* The heraldic ornaments were the only things in this retired place that reminded us of Europe. The church or chapel formed one side of a quadrangle, in the middle of which a large clump of bananas were growing. On another side was a hospital, containing about a dozen miserable-looking inmates.

We returned to the Vênda to eat our dinners. A considerable number of men, women, and children, all as black as jet, collected to watch us. Our companions were extremely merry; and everything we said or did was followed by their hearty laughter. Before leaving the town we visited the cathedral. It does not appear so rich as the smaller church, but boasts of a little organ, which sent forth singularly inharmonious cries. We presented the black priest with a few shillings, and the Spaniard, patting him on the head, said, with much candour, he thought his colour made no great difference. We then returned, as fast as the ponies would go, to Porto Praya.

Another day we rode to the village of St. Domingo, situated near the centre of the island. On a small plain which we crossed, a few stunted acacias were growing; their tops had been bent by the steady trade-wind, in a singular manner-some of them even at right angles to their trunks. The direction of the branches was exactly N.E. by N., and S.W. by S., and these natural vanes must indicate the prevailing direction of the force of the trade-wind. The travelling had made so little impression on the barren soil, that we here missed our track, and took that to Fuentes. This we did not find out till we arrived there; and we were afterwards glad of our mistake. Fuentes is a pretty village, with a small stream ; and everything appeared to prosper well, excepting, indeed, that which ought to do so most-iis

* The Cape de Verd Islands were discovered in 1449. There was a tombstone of a bishop with the date of 1571 ; and a crest of $a$ hand and dagger, dated 1497. 
inhabitants. The black children, completely naked, and looking very wretched, were carrying bundles of firewood half as big as their own bodies.

Near Fuentes we saw a large flock of guinea-fowl-probably fifty or sixty in number. They were extremely wary, and could not be approached. They avoided us, like partridges on a rainy day in September, running with their heads cocked up; and if pursued, they readily took to the wing.

The scenery of St. Domingo possesses a beauty totally unexpected, from the prevalent gloomy character of the rest of the island. The village is situated at the bottom of a valley, bounded by lofty and jagged walls of stratified lava. The black rocks afford a most striking contrast with the bright green vegetation, which follows the banks of a little stream of clear water. It happened to be a grand feast-day, and the village was full of people. On our return we overtook a party of about twenty young black girls, dressed in excellent taste; their black skins and snow-white linen being set off by coloured turbans and large shawls. As soon as we approached near, they suddenly all turned round, and covering the path with their shawls, sung with great energy a wild song, beating time with their hands upon their legs. We threw them some vintéms, which were received with screams of laughter, and we left them redoubling the noise of their song.

One morning the view was singularly elear ; the distant mountains being projected with the sharpest outline, on a heavy bank of dark blue clouds. Judging from the appearance, and from similar cases in England, I supposed that the air was saturated with moisture. The fact, however, turned out quite the contrary. The hygrometer gave a difference of $29 \cdot 6$ degrees, between the temperature of the air, and the point at which dew was precipitated. This difference was nearly double that which I had observed on the previous mornings. This unusual degree of atmospheric dryness was accompanied by continual flashes of lightning. Is it not an uncommon case, thus to find a remarkable degree of aerial transparency with such a state of weather?

Generally the atmosphere is hazy; and this is caused by the falling of impalpably fine dust, which was found to have slightly 
injured the astronomical instruments. The morning before we anchored at Porto Praya, I collected a little packet of this brown-coloured fine dust, which appeared to have been filtered from the wind by the gauze of the vane at the mast-head. Mr. Lyell has also given me four packets of dust which fell on a vessel a few hundred miles northward of these islands. Professor Ehrenberg* finds that this dust consists in great part of infusoria with siliceous shields, and of the siliceous tissue of plants. In five little packets which I sent him, he has ascertained no less than sixty-seven different organic forms! The infusoria, with the exception of two marine species, are all inhabitants of freshwater. I have found no less than fifteen different accounts of dust having fallen on vessels when far out in the Atlantic. From the direction of the wind whenever it has fallen, and from its having always fallen during those months when the harmattan is known to raise clouds of dust high into the atmosphere, we may feel sure that it all comes from Africa. It is, however, a very singular fact, that, although Professor Ehrenberg knows many species of infusoria peculiar to Africa, he finds none of these in the dust which I sent him : on the other hand, he finds in it two species which hitherto he knows as living only in South America. The dust falls in such quantities as to dirty everything on board, and to hurt people's eyes; vessels even have run on shore owing to the obscurity of the atmosphere. It has often fallen on ships when several hundred, and even more than a thousand miles from the coast of Africa, and at points sixteen hundred miles distant in a north and south direction. In some dust which was collected on a vessel three hundred miles from the land, I was much surprised to find particles of stone above the thousandth of an inch square, mixed with finer matter. After this fact one need not be surprised at the diffusion of the far lighter and smaller sporules of cryptogamic plants.

The geology of this island is the most interesting part of its natural history. On entering the harbour, a perfectly horizontal white band in the face of the sea cliff, may be seen running for

* I must take this opportunity of acknowledging the great kindness with which this illustrious naturalist has examined many of my specimens. I have sent (Jume, 1845) a full account of the falling of this dust to the Geological Society. 
some miles along the coast, and at the height of about forty-five feet above the water. Upon examination, this white stratum is found to consist of calcareous matter, with numerous shells embedded, most or all of which now exist on the neighbouring coast. It rests on ancient volcanic rocks, and has been covered by a stream of basalt, which must have entered the sea when the white shelly bed was lying at the bottom. It is interesting to trace the changes, produced by the heat of the overlying lava, on the friable mass, which in parts has been converted into a crystalline limestone, and in other parts into a compact spotted stone. Where the lime has been caught up by the scoriaceous fragments of the lower surface of the stream, it is converted into groups of beautifully radiated fibres resembling arragonite. The beds of lava rise in successive gently-sloping plains, towards the interior, whence the deluges of melted stone have originally proceeded. Within historical times, no signs of volcanic activity have, I believe, been manifested in any part of St. Jago. Even the form of a crater can but rarely be discovered on the summits of the many red cindery hills; yet the more recent streams can be distinguished on the coast, forming lines of cliffs of less height, but stretching out in advance of those belonging to an older series : the height of the cliffs thus affording a rude measure of the age of the streams.

During our stay, I observed the habits of some marine animals. A large Aplysia is very common. This sea-slug is about five inches long; and is of a dirty yellowish colour, veined with purple. On each side of the lower surface, or foot, there is a broad membrane, which appears sometimes to act as a ventilator, in causing a current of water to flow over the dorsal branchiæ or lungs. It feeds on the delicate sea-weeds which grow among the stones in muddy and shallow water; and I found in its stomach several small pebbles, as in the gizzard of a bird. This slug, when disturbed, emits a very fine purplish-red fluid, which stains the water for the space of a foot around. Besides this means of defence, an acrid secretion, which is spread over its body, causes a sharp, stinging sensation, similar to that produced by the Physalia, or Portuguese man-of-war.

I was much interested, on several occasions, by watching the habits of an Octopus, or cuttle-fish. Although common in the 
pools of water left by the retiring tide, these animals were not easily caught. By means of their long arms and suckers, they could drag their bodies into very narrow crevices; and when thus fixed, it required great force to remove them. At other times they darted tail first, with the rapidity of an arrow, from one side of the pool to the other, at the same instant discolouring the water with a dark chestnut-brown ink. These animals also escape detection by a very extraordinary, chameleon-like power of changing their colour. They appear to vary their tints according to the nature of the ground over which they pass: when in deep water, their general shade was brownish purple, but when placed on the land, or in shallow water, this dark tint changed into one of a yellowish green. The colour, examined more carefully, was a French grey, with numerous minute spots of bright yellow: the former of these varied in intensity; the latter entirely disappeared and appeared again by turns. These changes were effected in such a manner, that clouds, varying in tint between a hyacinth red and a chestnut brown,* were continually passing over the body. Any part, being subjected to a slight shock of galvanism, became almost black : a similar effect, but in a less degree, was produced by scratching the skin with a needle. These clouds, or blushes as they may be called, are said to be produced by the alternate expansion and contraction of minute vesicles containing variously coloured fluids. $\dagger$

This cuttle-fish displayed its chameleon-like power both during the act of swimming and whilst remaining stationary at the bottom. I was much amused by the various arts to escape detection used by one individual, which seemed fully aware that I was watching it. Remaining for a time motionless, it would then stealthily advance an inch or two, like a cat after a mouse; sometimes changing its colour : it thus proceeded, till having gained a deeper part, it darted away, leaving a dusky train of ink to hide the hole into which it had crawled.

While looking for marine animals, with my head about two feet above the rocky shore, I was more than once saluted by a jet of water, accompanied by a slight grating noise. At first I could not think what it was, but afterwards I found out that it was

* So named according to Patrick Symes's nomenclature.

† See Encyclop. of Anat. and Physiol., article Cephalopoda. 
this cuttle-fish, which, though concealed in a hole, thus often led me to its discovery. That it possesses the power of ejecting water there is no doubt, and it appeared to me that it could certainly take good aim by directing the tube or siphon on the under side of its body. From the difficulty which these animals have in carrying their heads, they cannot crawl with ease when placed on the ground. I observed that one which I kept in the cabin was slightly phosphorescent in the dark.

St. Paul's Rocks.-In crossing the Atlantic we hove-to, during the morning of February 16th, close to the island of St. Paul's. This cluster of rocks is situated in $0^{\circ} 58^{\prime}$ north latitude, and $29^{\circ} 15^{\prime}$ west longitude. It is 540 miles distant from the coast of America, and 350 from the island of Fernando Noronha. The highest point is only fifty feet above the level of the sea, and the entire circumference is under three-quarters of a mile. This small point rises abruptly out of the depths of the ocean. Its mineralogical constitution is not simple; in some parts the rock is of a cherty, in others of a felspathic nature, including thin veins of serpentine. It is a remarkable fact, that all the many small islands, lying far from any continent, in the Pacific, Indian, and Atlantic Oceans, with the exception of the Seychelles and this little point of rock, are, I believe, composed either of coral or of erupted matter. The volcanic nature of these oceanic islands is evidently an extension of that law, and the effect of those same causes, whether chemical or mechanical, from which it results that a vast majority of the volcanoes now in action stand either near sea-coasts or as islands in the midst of the sea.

The rocks of St. Paul appear from a distance of a brilliantly white colour. This is partly owing to the dung of a vast multitude of seafowl, and partly to a coating of a hard glossy substance with a pearly lustre, which is intimately united to the surface of the rocks. This, when examined with a lens, is found to consist of numerous exceedingly thin layers, its total thickness being about the tenth of an inch. It contains much animal matter, and its origin, no doubt, is due to the action of the rain or spray on the birds' dung. Below some small masses of guano at Ascension, and on the Abrolhos Islets, I found certain stalactitic branching bodies, formed apparently in the same manner as 
the thin white coating on these rocks. The branching bodies so closely resembled in general appearance certain nulliporæ (a family of hard calcareous sea-plants), that in lately looking hastily over my collection I did not perceive the difference. The globular extremities of the branches are of a pearly texture, like the enamel of teeth, but so hard as just to scratch plate-glass. I may here mention, that on a part of the coast of Ascension, where there is a vast accumulation of shelly sand, an incrustation is deposited on the tidal rocks, by the water of the sea, resembling, as represented in the woodcut, certain cryptogamic plants (Marchantiæ) often seen on damp walls. The surface of the fronds is

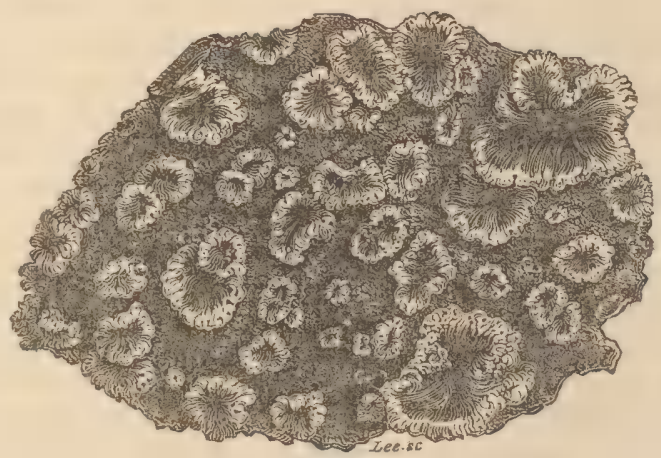

beautifully glossy; and those parts formed where fully exposed to the light, are of a jet black colour, but those shaded under ledges are only grey. I have shown specimens of this incrustation to several geologists, and they all thought that they were of volcanic or igneous origin! In its hardness and translucencyin its polish, equal to that of the finest oliva-shell-in the bad smell given out, and loss of colour under the blowpipe-it shows a close similarity with living sea-shells. Moreover in sea-shells, it is known that the parts habitually covered and shaded by the mantle of the animal, are of a paler colour than those fully exposed to the light, just as is the case with this incrustation. When we remember that lime, either as a phosphate or carbonate, enters into the composition of the hard parts, such as bones and 
shells, of all living animals, it is an interesting physiological fact * to find substances harder than the enamel of teeth, and coloured surfaces as well polished as those of a fresh shell, reformed through inorganic means from dead organic mattermocking, also, in shape some of the lower vegetable productions.

We found on St. Paul's only two kinds of birds-the booby and the noddy. The former is a species of gannet, and the latter a tern. Both are of a tame and stupid disposition, and are so unaccustomed to visitors, that I could have killed any number of them with my geological hammer. The booby lays her eggs on the bare rock; but the tern makes a very simple nest with seaweed. By the side of many of these nests a small Alying-fish was placed; which, I suppose, had been brought by the male bird for its partner. It was amusing to watch how quickly a large and active crab (Graspus), which inhabits the crevices of the rock, stole the fish from the side of the nest, as soon as we had disturbed the parent birds. Sir W. Symonds, one of the few persons who have landed here, informs me that he saw the crabs dragging even the young birds out of their nests, and devouring them. Not a single plant, not even a lichen, grows on this islet; yet it is inhabited by several insects and spiders. The following list completes, I believe, the terrestrial fauna: a fly (Olfersia) living on the booby, and a tick which must, have come here as a parasite on the birds; a small brown moth, belonging to a genus that feeds on feathers; a beetle (Quedius) and a woodlouse from beneath the dung; and lastly, numerous spiders, which I suppose prey on these small attendants and scavengers of the waterfowl. The often repeated description of the stately palm and other noble tropical plants, then birds, and lastly man, taking possession of the coral islets as soon as formed, in the Pacific, is probably not quite correct; I fear it destroys the poetry of this story, that feather and dirt-

* Mr. Horner and Sir David Brewster have described (Philosophical Transactions, 1836, p. 65) a singular "artificial substance resembling shell." It is deposited in fine, transparent, highly polished, brown-coloured laminæ, possessing peculiar optical properties, on the inside of a vessel, in which cloth, first prepared with glue and then with lime, is made to revolve rapidly in water. It is much softer, more transparent, and contains more animal matter, than the natural incrustation at Ascension; but we here again see the strong tendency which carbonate of lime and animal matter evince to form a solid substance allied to shell. 
feeding and parasitic insects and spiders should be the first inhabitants of newly formed oceanic land.

The smallest rock in the tropical seas, by giving a foundation for the growth of innumerable kinds of seaweed and compound animals, supports likewise a large number of fish. The sharks and the seamen in the boats maintained a constant struggle which should secure the greater share of the prey caught by the fishing-lines. I have heard that a rock near the Bermudas, lying many miles out at sea, and at a considerable depth, was first discovered by the circumstance of fish having been observed in the neighbourhood.

Fernando Noronha, Feb. 20th.-As far as I was enabled to observe, during the few hours we stayed at this place, the constitution of the island is volcanic, but probably not of a recent date. The most remarkable feature is a conical hill, about one thousand feet high, the upper part of which is exceedingly steep, and on one side overhangs its base. The rock is phonolite, and is divided into irregular columns. On viewing one of these isolated masses, at first one is inclined to believe that it has been suddenly pushed up in a semi-fluid state. At St. Helena, however, I ascertained that some pinnacles, of a nearly similar figure and constitution, had been formed by the injection of melted rock into yielding strata, which thus had formed the moulds for these gigantic obelisks. The whole island is covered with wood; but from the dryness of the climate there is no appearance of luxuriance. Half-way up the mountain, some great masses of the columnar rock, shaded by laurel-like trees, and ornamented by others covered with fine pink flowers but withont a single leaf, gave a pleasing effect to the nearer parts of the scenery.

Bahia, or San Salvador. Brazil, Feb. 29th.-The day has past delightfully. Delight itself, however, is a weak term to express the feelings of a naturalist who, for the first time, has wandered by himself' in a Brazilian forest. 'The elegance of the grasses, the novelty of the parasitical plants, the beauty of the flowers, the glossy green of the foliage, but above all the general luxuriance of the vegetation, filled me with admiration. A most paradoxical mixture of sound and silence pervades the 
shady parts of the wood. The noise from the insects is so loud, that it may be heard even in a vessel anchored several hundred yards from the shore; yet within the recesses of the forest a universal silence appears to reign. To a person fond of natural history, such a day as this brings with it a deeper pleasure than he can ever hope to experience again. After wandering about for some hours, I returned to the landing-place; but, before reaching it, I was overtaken by a tropical storm. I tried to find shelter under a tree, which was so thick that it would never have been penetrated by common English rain; but here, in a couple of minutes, a little torrent flowed down the trunk. It is to this violence of the rain that we must attribute the verdure at the bottom of the thickest woods: if the showers were like those of a colder clime, the greater part would be absorbed or evaporated before it reached the ground. I will not at present attempt to describe the gaudy scenery of this noble bay, because, in our homeward voyage, we called here a second time, and I shall then have occasion to remark on it.

Along the whole coast of Brazil, for a length of at least 2000 miles, and certainly for a considerable space inland, wherever solid rock occurs, it belongs to a granitic formation. The circumstance of this enormous area being constituted of materials which most geologists believe to have been crystallized when heated under pressure, gives rise to many curious reflections. Was this effect produced beneath the depths of a profound ocean? or did a covering of strata formerly extend over it, which has since been removed? Can we believe that any power, acting for a time short of infinity, could have denuded the granite over
so many thousand square leagues?

On a point not far from the city, where a rivulet entered the sea, I observed a fact connected with a subject discussed by Humboldt.* At the cataracts of the great rivers Orinoco, Nile, and Congo, the syenitic rocks are coated by a black substance, appearing as if they had been polished with plumbago. The layer is of extreme thinness; and on analysis by Berzelius it was found to consist of the oxides of manganese and iron. In the Orinoco it occurs on the rocks periodically washed by the floods, and in those parts alone where the stream is rapid; or, as the

* Pers. Narr., vol. v. pt. i. p. 18. 
Indians say, "the rocks are black where the waters are white." Here the coating is of a rich brown instead of a black colour, and seems to be composed of ferruginous matter alone. Hand specimens fail to give a just idea of these brown burnished stones which glitter in the sun's rays. They occur only within the limits of the tidal waves; and as the rivulet slowly trickles down, the surf must supply the polishing power of the cataracts in the great rivers. In like manner, the rise and fall of the tide probably answer to the periodical inundations; and thus the same effects are produced under apparently different but really similar circumstances. The origin, however, of these coatings of metallic oxides, which seem as if cemented to the rocks, is not understood; and no reason, I believe, can be assigned for their thickness remaining the same.

One day I was amused by watching the habits of the Diodon antennatus, which was caught swimming near the shore. This fish, with its flabby skin, is well known to possess the singular power of distending itself into a nearly spherical form. After having been taken out of water for a short time, and then again immersed in it, a considerable quantity both of water and air is absorbed by the mouth, and perhaps likewise by the branchial orifices. This process is effected by two methods: the air is swallowed, and is then forced into the cavity of the body, its return being prevented by a muscular contraction which is externally visible: but the water enters in a gentle stream through the mouth, which is kept wide open and motionless; this latter action must, therefore, depend on suction. The skin about the abdomen is much looser than that on the back; hence, during the inflation, the lower surface becomes far more distencled than the upper; and the fish, in consequence, floats with its back downwards. Cuvier doubts whether the Diodon in this position is able to swim; but not only can it thus move forward in a straight line, but it can turn round to either side. This latter movement is effected solely by the aid of the pectoral fins; the tail being collapsed, and not used. From the body being buoyed up with so much air, the branchial openings are out of water, but a stream drawn in by the mouth constantly flows through them.

The fish, having remained in this distencled state for a short 
time, generally expelled the air and water with considerable force from the branchial apertures and mouth. It could emit, at will, a certain portion of the water; and it appears, therefore, probable that this fluid is taken in partly for the sake of regulating its specific gravity. This Diodon possessed several means of defence. It could give a severe bite, and could eject water from its mouth to some distance, at the same time making a curious noise by the movement of its jaws. By the inflation of its body, the papillæ, with which the skin is covered, become erect and pointed. But the most curious circumstance is, that it secretes from the skin of its belly, when handled, a most beautiful carmine-red fibrous matter, which stains ivory and paper in so permanent a manner, that the tint is retained with all its brightness to the present day: I am quite ignorant of the nature and use of this secretion. I have heard from Dr. Allan of Forres, that he has frequently found a Diodon, floating alive and distended, in the stomach of the shark; and that on several occasions he has known it eat its way, not only through the coats of the stomach, but through the sides of the monster, which has thus been killed. Who would ever have imagined that a little soft fish could have destroyed the great and savage shark?

March 18th.-We sailed from Bahia. A few days afterwards, when not far distant from the Abrolhos Islets, my attention was called to a reddish-brown appearance in the sea. The whole surface of the water, as it appeared under a weak lens, seemed as if covered by chopped bits of hay, with their ends jagged. These are minute cylindrical confervæ, in bundles or rafts of from twenty to sixty in each. Mr. Berkeley informs me that they are the same species (Trichodesmium erythræum) with that found over large spaces in the Red Sea, and whence its name of Red Sea is derived.* Their numbers must be infinite : the ship passed through several bands of them, one of which was about ten yards wide, and, judging from the mud-like colour of the water, at least two and a half miles long. In almost every long voyage some account is given of these confervæ. They appear especially common in the sea near Australia; and off Cape Leeuwin I found an * M. Montagne, in Cumptes Rendus, \&c., Juillet, 1844; and Annal. des
Scienc. Nat., Dec. 1844. 
allied, but smaller and apparently different species. Captain Cook, in his third voyage, remarks, that the sailors gave to this appearance the name of sea-sawdust.

Near Keeling Atoll, in the Indian Ocean, I observed many little masses of confervæ a few inches square, consisting of long cylindrical threads of excessive thinness, so as to be barely visible to the naked eye, mingled with other rather larger bodies, finely conical at both ends. Two of these are shown in the woodcut united together. They vary in length from $\cdot 04$ to $\cdot 06$, and even to $\cdot 08$ of an

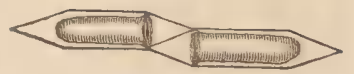
inch in length; and in diameter from 006 to 008 of a inch. Near one extremity of the cylindrical part, a green septum, formed of granular matter, and thickest in the middle, may generally be seen. This, I believe, is the bottom of a most delicate, colourless sac, composed of a pulpy substance, which lines the exterior case, but does not extend within the extreme conical points. In some specimens, small but perfect spheres of brownish granular matter supplied the places of the septa; and I observed the curious process by which they were produced. The pulpy matter of the internal coating suddenly grouped itself into lines, some of which assumed a form radiating from a common centre; it then continued, with an irregular and rapid movement, to contract itself, so that in the course of a second the whole was united into a perfect little sphere, which occupied the position of the septum at one end of the now quite hollow case. The formation of the granular sphere was hastened by any accidental injury. I may add, that frequently a pair of these bodies were attached to each other, as represented above, cone beside cone, at that end where the septum occurs.

I will here add a few other observations connected with the discoloration of the sea from organic causes. On the coast of Chile, a few leagues north of Concepcion, the Beagle one day passed through great bands of muddy water, exactly like that of a swollen river; and again, a degree south of Valparaiso, when fifty miles from the land, the same appearance was still more extensive. Some of the water placed in a glass was of a pale reddish tint; and, examined under a microscope, was seen to swarm with minute animalcula darting about, and often explod- 
ing. Their shape is oval, and contracted in the middle by a ring of vibrating curved ciliæ. It was, however, very difficult to examine them with care, for almost the instant motion ceased, even while crossing the field of vision, their bodies burst. Sometimes both ends burst at once, sometimes only one, and a quantity of coarse, brownish, granular matter was ejected. The animal an instant before bursting expanded to half again its natural size; and the explosion took place about fifteen seconds after the rapid progressive motion had ceased: in a few cases it was preceded for a short interval by a rotatory movement on the longer axis. About two minutes after any number were isolated in a drop of water, they thus perished. The animals move with the narrow apex forwards, by the aid of their vibratory ciliæ, and generally by rapid starts. They are exceedingly minute, and quite invisible to the naked eye, only covering a space equal to the square of the thousandth of an inch. Their numbers were infinite; for the smallest drop of water which I could remove contained very many. In one day we passed through two spaces of water thus stained, one of which alone must have extended over several square miles. What incalculable numbers of these microscopical animals! The colour of the water, as seen at some distance, was like that of a river which has flowed through a red clay district; but under the shade of the vessel's side it was quite as dark as chocolate. The line where the red and blue water joined was distinctly defined. The weather for some days previously had been calm, and the ocean abounded, to an unusual degree, with living creatures.*

In the sea around Tierra del Fuego, and at no great distance from the land, I have seen narrow lines of water of a bright red colour, from the number of crustacea, which somewhat resemble in form large prawns. The sealers call them whale-food. Whether whales feed on them I do not know ; but terns, cormo-

*. Lesson (Voyage de la Coquille, tom. i., p. 255) mentions red water off Lima, apparently produced by the same cause. Peron, the distinguished naturalist, in the Voyage aux Terres Australes, gives no less than twelve references to voyagers who have alluded to the discoloured waters of the sea (vol. ii. p. 239). 'To the references given by Peron may be added, Hum-
boldt's Pers. Narr., vol. vi. p. 804 ; Flinders' Voyage, vol. i. p. 92; Labil-
lardière, vol. i. p. 287 ; Ulloa's Voyage. Voyan lardière, vol. i. p. 287; Ulloa's Voyage; Voyage of the Astrolabe and of the Coquille; Captain King's Survey of Australia, \&c. 
rants, and immense herds of great unwieldy seals derive, on some parts of the coast, their chief sustenance from these swimming crabs. Seamen invariably attribute the discoloration of the water to spawn; but I found this to be the case only on one occasion. At the distance of several leagues from the Archipelago of the Galapagos, the ship sailed through three strips of a dark yellowish, or mud-like water; these strips were some miles long, but only a few yards wide, and they were separated from the surrounding water by a sinuous yet distinct margin. The colour was caused by little gelatinous balls, about the fifth of an inch in diameter, in which numerous minute spherical ovules were embedded : they were of two distinct kinds, one being of a reddish colour and of a different shape from the other. I cannot form a conjecture as to what two kinds of animals these belonged. Captain Colnett remarks, that this appearance is very common among the Galapagos Islands, and that the direction of the bands indicates that of the currents; in the described case, however, the line was caused by the wind. The only other appearance which I have to notice, is a thin oily coat on the water which displays iridescent colours. I saw a considerable tract of the ocean thus covered on the coast of Brazil ; the seamen attributed it to the putrefying carcass of some whale, which probably was floating at no great distance. I do not here mention the minute gelatinous particles, hereafter to be referred to, which are frequently dispersed throughout the water, for they are not sufficiently abundant to create any change of colour.

'There are two circumstances in the above accounts which appear remarkable: first, how do the various bodies which form the bands with defined edges keep together? In the case of the prawn-like crabs, their movements were as coinstantaneous as in a regiment of soldiers; but this cannot happen from any thing like voluntary action with the ovules, or the confervæ, nor is it probable among the infusoria. Secondly, what causes the length and narrowness of the bands? The appearance so much resembles that which may be seen in every torrent, where the stream uncoils into long streaks the froth collected in the eddies, that I must attribute the effect to a similar action either of the currents of the air or sea. Under this supposition we must believe that the various organized bodies are produced in certain favour- 
able places, and are thence removed by the set of either wind or water. I confess, however, there is a very great difficulty in imagining any one spot to be the birthplace of the millions of millions of animalcula and confervæ: for whence come the germs at such points? - the parent bodies having been distributed by the winds and waves over the immense ocean. But on no other hypothesis can $I$ understand their linear grouping. I may add that Scoresby remarks, that green water abounding with pelagic animals is invariably found in a certain part of the Arctic Sea. 


\section{CHAPTER II.}

Rio de Janeiro-Excursion north of Cape Frio-Great Evaporation-Slavery -Botofogo Bay-Terrestrial Planariæ-Clouds on the Corcovado-Heavy Rain-Musical Frogs-Phosphorescent Insects-Elater, springing powers of-Blue Haze-Noise made by a Butterfly-Entomology-Ants-Wasp killing a Spider-Parasitical Spider-Artifices of an Epeira-Gregarious Spider-Spider with an unsymmetrical Web.

\section{RIO DE JANEIRO.}

April 4th to July 5th, 1832.-A few days after our arrival I became acquainted with an Englishman who was going to visit his estate, situated, rather more than a hundred miles from the capital, to the northward of Cape Frio. I gladly accepted his kind offer of allowing me to accompany him.

April 8th.-Our party amounted to seven. The first stage was very interesting. The day was powerfully hot, and as we passed through the woods, every thing was motionless, excepting the large and brilliant butterflies, which lazily fluttered about. 'The view seen when crossing the hills behind Praia Grande was most beautiful ; the colours were intense, and the prevailing tint a dark blue; the sky and the calm waters of the bay vied with each other in splendour. After passing through some cultivated country, we entered a forest, which in the grandeur of all its parts could not be exceeded. We arrived by midday at Ithacaia; this small village is situated on a plain, and round the central house are the huts of the negroes. These, from their regular form and position, reminded me of the drawings of the Hottentot habitations in Southern Africa. As the moon rose early, we determined to start the same evening for our sleepingplace at the Lagoa Marica. As it was growing dark we passed under one of the massive, bare, and steep hills of granite which are so common in this country. This spot is notorious from having been, for a long time, the residence of some runaway slaves, who, by cultivating a little ground near the top, con- 
trived to eke out a subsistence. At length they were discovered, and a party of soldiers being sent, the whole were seized with the exception of one old woman, who, sooner than again be led into slavery, dashed herself to pieces from the summit of the mountain. In a Roman matron this would have been called the noble love of freedom: in a poor negress it is mere brutal obstinacy. We continued riding for some hours. For the few last miles the road was intricate, and it passed through a desert waste of marshes and lagoons. The scene by the dimmed light of the moon was most desolate. A few fireflies flitted by us; and the solitary snipe, as it rose, uttered its plaintive cry. The distant and sullen roar of the sea scarcely broke the stillness of the night.

April 9th.-We left our miserable sleeping-place before sunrise. The road passed through a narrow sandy plain, lying between the sea and the interior salt lagoons. The number of beautiful fishing birds, such as egrets and cranes, and the succulent plants assuming most fantastical forms, gave to the scene an interest which it would not otherwise have possessed. The few stunted trees were loaded with parasitical plants, among which the beauty and delicious fragrance of some of the orchider were most to be admired. As the sun rose, the day became extremely hot, and the reflection of the light and heat from the white sand was very distressing. We dined at Mandetiba ; the thermometer in the shade being $84^{\circ}$. The beautiful view of the distant wooded hills, reflected in the perfectly calm water of an extensive lagoon, quite refreshed us. As the vênda* here was a very good one, and I have the pleasant, but rare remembrance, of an excellent dinner, I will be grateful and presently describe it, as the type of its class. These houses are often large, and are built of thick upright posts, with boughs interwoven, and afterwards plastered. They seldom have floors, and never glazed windows; but are generally pretty well roofed. Universally the front part is open, forming a kind of verandah, in which tables and benches are placed. The bed-rooms join on each side, and here the passenger may sleep as comfortably as he can, on a wooden platform, covered by a thin straw mat. The vênda stands in a courtyard, where the horses are fed. On first arriving, it was our custom

- Vênda, the Portuguese name for an inn 
to unsaddle the horses and give them their Indian corn; then, with a low bow, to ask the senhôr to do us the favour to give us something to eat. " "Any thing you choose, sir," was his usual answer. For the few first times, vainly I thanked providence for having guided us to so good a man. The conversation proceeding, the case universally became deplorable. "Any fish can you do us the favour of giving?"_-6" Oh! no, sir." - "Any

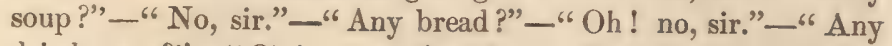
dried meat?"- "Oh! no, sir." If we were lucky, by waiting a couple of hours, we obtained fowls, rice, and farinha. It not unfrequently happened, that we were obliged to kill, with stones, the poultry for our own supper. When, thoroughly exhausted by fatigue and hunger, we timorously hinted that we should be glad of our meal, the pompous, and (though true) most unsatisfactory answer was, "It will be ready when it is ready." If we had dared to remonstrate any further, we should have been told to proceed on our journey, as being too impertinent. The hosts are most ungracious and disagreeable in their manners; their houses and their persons are often filthily dirty; the want of the accommodation of forks, knives, and spoons is common; and I am sure no cottage or hovel in England could be found in a state so utterly destitute of every comfort. At Campos Novos, however, we fared sumptuously; having rice and fowls, biscuit, wine, and spirits, for dinner; coffee in the evening, and fish with coffee for breakfast. All this, with good food for the horses, only cost $2 s$. $6 d$. per head. Yet the host of this vênda, being asked if he knew any thing of a whip which one of the party had lost, gruffly answered, " How should I know? why did you not take care of it? - I suppose the dogs have eaten it."

Leaving Mandetiba, we continued to pass through an intricate wilderness of lakes; in some of which were fresh, in others salt water shells. Of the former kind, I found a Limnæa in great numbers in a lake, into which, the inhabitants assured me that the sea enters once a year, and sometimes oftener, and makes the water quite salt. I have no doubt many interesting facts, in relation to marine and fresh water animals, might be observed in this chain of lagoons, which skirt the coast of Brazil. M. Gay* has stated that he found in the neighbourhood of Rio,

- Annales des Sciences Naturelles for 1833. 
shells of the marine genera solen and mytilus, and fresh water ampullariæ, living together in brackish water. I also frequently observed in the lagoon near the Botanic Garden, where the water is only a little less salt than in the sea, a species of hydrophilus, very similar to a water-beetle common in the ditches of England: in the same lake the only shell belonged to a genus generally found in estuaries.

Leaving the coast for a time, we again entered the forest. The trees were very lofty, and remarkable, compared with those of Europe, from the whiteness of their trunks. I see by my notebook, "wonderful and beautiful, flowering parasites," invariably struck me as the most novel object in these grand scenes. Travelling onwards we passed through tracts of pasturage, much injured by the enormous conical ants' nests, which were nearly twelve feet high. They gave to the plain exactly the appearance of the mud volcanos at Jorullo, as figured by Humboldt. We arrived at Engenhodo after it was dark, having been ten hours on horseback. I never ceased, during the whole journey, to be surprised at the amount of labour which the horses were capable of enduring; they appeared also to recover from any injury much sooner than those of our English breed. The Vampire bat is often the cause of much trouble, by biting the horses on their withers. The injury is generally not so much owing to the loss of blood, as to the inflammation which the pressure of the saddle afterwards produces. The whole circumstance has lately been doubted in England; I was therefore fortunate in being present when one (Desmodus d'orbignyi, Wat.) was actually caught on a horse's back. We were bivouacking late one evening near Coquimbo, in Chile, when my servant, noticing that one of the horses was very restive, went to see what was the matter, and fancying he could distinguish something, suddenly put his hand on the beast's withers, and secured the vampire. In the morning the spot where the bite had been inflicted was easily distinguished from being slightly swollen and bloody. The third day afterwards we rode the horse, without any ill effects.

April 13th.-After three days' travelling we arrived at Socêgo, the estate of Senhôr Manuel Figuireda, a relation of one of our party. The house was simple, and, though like a barn in form, 
was well suited to the climate. In the sitting-room gilded chairs and sofas were oddly contrasted with the whitewashed walls, thatched roof, and windows without glass. The house, together with the granaries, the stables, and workshops for the blacks, who had been taught various trades, formed a rude kind of quadrangle; in the centre of which a large pile of coffee was drying. These buildings stand on a little hill, overlooking the cultivated ground, and surrounded on every side by a wall of dark green luxuriant forest. The chief produce of this part of the country is coffee. Each tree is supposed to yield annually, on an average, two pounds; but some give as much as eight. Mandioca or cassada is likewise cultivated in great quantity. Every part of this plant is useful : the leaves and stalks are eaten by the horses, and the roots are ground into a pulp, which, when pressed dry and baked, forms the farinha, the principal article of sustenance in the Brazils. It is a curious, though well-known fact, that the juice of this most nutritious plant is highly poisonous. A few years ago a cow died at this Fazênda, in consequence of having drunk some of it. Senhôr Figuireda told me that he had planted, the year before, one bag of feijaô or beans, and three of rice; the former of which produced eighty, and the latter three hundreul and twenty fold. The pasturage supports a fine stock of cattle, and the woods are so full of game, that a deer had been killed on each of the three previous days. This profusion of food showed itself at dinner, where, if the tables did not groan, the guests surely did : for each person is expected to eat of every dish. One day, having, as I thought, nicely calculated so that nothing should go away untasted, to my utter dismay a roast turkey and a pig appeared in all their substantial reality. During the meals, it was the employment of a man to drive out of the room sundry old hounds, and dozens of little black children, which crawled in together, at every opportunity. As long as the idea of slavery could be banished, there was something exceedingly fascinating in this simple and patriarchal style of living: it was such a perfect retirement and independence from the rest of the world. As soon as any stranger is seen arriving, a large bell is set tolling, and generally some small cannon are fired. The event is thus announced to the rocks and woods, but to nothing else. One morning I walked out an hour before day- 
light to admire the solemn stillness of the scene; at last, the silence was broken by the morning hymn, raised on high by the whole body of the blacks; and in this manner their daily work is generally begun. On such fazêndas as these, I have no doubt the slaves pass happy and contented lives. On Saturday and Sunday they work for themselves, and in this fertile climate the labour of two days is sufficient to support a man and his family for the whole week.

April 14th.-Leaving Socêgo, we rode to another estate on the Rio Macâe, which was the last patch of cultivated ground in that direction. The estate was two and a half miles long, and the owner had forgotten how many broad. Only a very small piece had been cleared, yet almost every acre was capable of yielding all the various rich productions of a tropical land. Considering the enormous area of Brazil, the proportion of cultivated ground can scarcely be considered as any thing, compared to that which is left in the state of nature: at some future age, how vast a population it will support! During the second day's journey we found the road so shut up, that it was necessary that a man should go ahead with a sword to cut away the creepers. The forest abounded with beautiful objects; among which the tree ferns, though not large, were, from their bright green foliage, and the elegant curvature of their fronds, most worthy of admiration. In the evening it rained very heavily, and although the thermometer stood at $65^{\circ}$, I felt very cold. As soon as the rain ceased, it was curious to observe the extraordinary evaporation which commenced over the whole extent of the forest. At the height of a hundred feet the hills were buried in a dense white vapour, which rose like columns of smoke from the most thickly-wooded parts, and especially from the valleys. I observed this phenomenon on several occasions: I suppose it is owing to the large surface of foliage, previously heated by the sun's rays.

While staying at this estate, I was very nearly being an eyewitness to one of those atrocious acts which can only take place in a slave country. Owing to a quarrel and a law-suit, the owner was on the point of taking all the women and children from the male slaves, and selling them separately at the public auction at Rio. Interest, and not any feeling of compassion, 
prevented this act. Indeed, I do not believe the inhumanity of separating thirty families, who had lived together for many years, even occurred to the owner. Yet I will pledge myself, that in humanity and good feeling he was superior to the common run of men. It may be said there exists no limit to the blindness of interest and selfish habit. I may mention one very trifling anecdote, which at the time struck me more forcibly than any story of cruelty. I was crossing a ferry with a negro, who was uncommonly stupid. In endeavouring to make him understand, I talked loud, and made signs, in doing which I passed my hand near his face. He, I suppose, thought I was in a passion, and was going to strike him; for instantly, with a frightened look and half-shut eyes, he dropped his hands. I shall never forget my feelings of surprise, disgust, and shame, at seeing a great powerful man afraid even to ward off a blow, directed, as he thought, at his face. This man had been trained to a degradation lower than the slavery of the most helpless animal.

April 18th.-In returning we spent two days at Socêgo, and I employed them in collecting insects in the forest. The greater number of trees, although so lofty, are not more than three or four feet in circumference. There are, of course, $n$ few of much greater dimension. Senhôr Manuel was then making a canoe 70 feet in length from a solid trunk, which had originally been 110 feet long, and of great thickness. The contrast of palm trees, growing amidst the common branching kinds, never fails to give the scene an intertropical character. Here the woods were ornamented by the Cabbage Palm-one of the most beautiful of its family. With a stem so narrow that it might be clasped with the two hands, it waves its elegant head at the height of forty or fifty feet above the ground. The woody creepers, themselves covered by other creepers, were of great thickness : some which I measured were two feet in circumference. Many of the older trees presented a very curious appearance from the tresses of a liana hanging from their boughs, and resembling bundles of hay. If the eye was turned from the world of foliage above, to the ground beneath, it was attracted by the extreme elegance of the leaves of the ferns and mimosæ. The latter, in some parts, covered the surface with a brushwood only a few inches high. In walking across these thick beds of mimoæs, a broad track 
was marked by the change of shade, produced by the drooping of their sensitive petioles. It is easy to specify the individual objects of admiration in these grand scenes; but it is not possible to give an adequate idea of the higher feelings of wonder, astonishment, and devotion, which fill and elevate the mind.

April 19th.-Leaving Socêgo, during the two first days, we retraced our steps. It was very wearisome work, as the road generally ran across a glaring hot sandy plain, not far from the coast. I noticed that each time the horse put its foot on the fine siliceous sand, a gentle chirping noise was produced. On the third day we took a different line, and passed through the gay little village of Madre de Deôs. This is one of the principal lines of road in Brazil ; yet it was in so bad a state that no wheel vehicle, excepting the clumsy bullock-waggon, could pass along. In our whole journey we did not cross a single bridge built of stone; and those made of logs of wood were frequently so much out of repair, that it was necessary to go on one side to avoid them. All distances are inaccurately known. The road is often marked by crosses, in the place of milestones, to signify where human blood has been spilled. On the evening of the 23rd we arrived at Rio, having finished our pleasant little excursion.

During the remainder of my stay at Rio, I resided in a cottage at Botofogo Bay. It was impossible to wish for anything more delightful than thus to spend some weeks in so magnificent a country. In England any person fond of natural history enjoys in his walks a great advantage, by always having something to attract his attention; but in these fertile climates, teeming with life, the attractions are so numerous, that he is scarcely able to walk at all.

'The few observations which I was enabled to make were almost exclusively confined to the invertebrate animals. The existence of a division of the genus Planaria, which inhabits the dry land, interested me much. These animals are of so simple a structure, that Cuvier has arranged them with the intestinal worms, though never found within the bodies of other animals. Numerous species inhabit both salt and fresh water; but those to which I allude were found, even in the drier parts of the forest, 
beneath logs of rotten wood, on which I believe they feed. In general form they resemble little slugs, but are very much narrower in proportion, and several of the species are beautifully coloured with longitudinal stripes. 'Their structure is very simple: near the middle of the under or crawling surface there are two small transverse slits, from the anterior one of which a funnel-shaped and highly irritable mouth can be protruded. For some time after the rest of the animal was completely dead from the effects of salt water or any other cause, this organ still retained its vitality.

I found no less than twelve different species of terrestrial Planariæ in different parts of the southern hemisphere.* Some specimens which I obtained at Van Diemen's Land, I kept alive for nearly two months, feeding them on rotten wood. Having cut one of them transversely into two nearly equal parts, in the course of a fortnight both had the shape of perfect animals. I had, however, so divided the body, that one of the halves contained both the inferior orifices, and the other, in consequence, none. In the course of twenty-five days from the operation, the more perfect half could not have been distinguished from any other specimen. The other had increased much in size; and towards its posterior end, a clear space was formed, in the parenchymatous mass, in which a rudimentary cup-shaped mouth could clearly be distinguished; on the under surface, however, no corresponding slit was yet open. If the increased heat of the weather, as we approached the equator, had not destroyed all the individuals, there can be no doubt that this last step would have completed its structure. Although so well-known an experiment, it was interesting to watch the gradual production of every essential organ, out of the simple extremity of another animal. It is extremely difficult to preserve these Planariæ; as soon as the cessation of life allows the ordinary laws of change to act, their entire bodies become soft and fluid, with a rapidity which I have never seen equalled.

I first visited the forest in which these Planariæ were found, in company with an old Portuguese priest who took me out to hunt with him. The sport consisted in turning into the cover

* I have described and named these species in the 'Annals of Nat. Hist.,' vol. xiv. p. 241. 
a few dogs, and then patiently waiting to fire at any animal which might appear. We were accompanied by the son of a neighbouring farmer-a good specimen of a wild Brazilian youth. He was dressed in a tattered old shirt and trousers, and had his head uncovered: he carried an old-fashioned gun and a large knife. The habit of carrying the knife is universal; and in traversing a thick wood it is almost necessary, on account of the creeping plants. The frequent occurrence of murder may be partly attributed to this habit. 'The Brazilians are so dexterous with the knife, that they can throw it to some distance with precision, and with sufficient force to cause a fatal wound. I have seen a number of little boys practising this art as a game of play, and from their skill in hitting an upright stick, they promised well for more earnest attempts. My companion, the day before, had shot two large bearded monkeys. 'These animals have prehensile tails, the extremity of which, even after death, can support the whole weight of the body. One of them thus remained fast to a branch, and it was necessary to cut down a large tree to procure it. This was soon effected, and down came tree and monkey with an awful crash. Our day's sport, besides the monkey, was confined to sundry small green parrots and a few toucans. I profited, however, by my acquaintance with the Portuguese padre, for on another occasion he gave me a fine specimen of the Yagouaroundi cat.

Every one has heard of the beauty of the scenery near Botofogo. The house in which I lived was seated close beneath the well-known mountain of the Corcovado. It has been remarked, with much truth, that abruptly conical hills are characteristic of the formation which Humboldt designates as gneiss-grainite. Nothing can be more striking than the effect of these huge rounded masses of naked rock rising out of the most luxuriant vegetation.

I was often interested by watching the clouds, which, rolling in from seaward, formed a bank just beneath the highest point of the Corcovado. This mountain, like most others, when thus partly veiled, appeared to rise to a far prouder elevation than its real height of 2300 feet. Mr. Daniell has observed, in his meteorological essays, that a cloud sometimes appears fixed on a mountain summit, while the wind continues to blow over it. 
The same phenomenon here presented a slightly different appearance. In this case the cloud was clearly seen to curl over, and rapidly pass by the summit, and yet was neither diminished nor increased in size. The sun was setting, and a gentle southerly breeze, striking against the southern side of the rock, mingled its current with the colder air above; and the vapour was thus condensed: but as the light wreaths of cloud passed over the ridge, and came within the influence of the warmer atmosphere of the northern sloping bank, they were immediately redissolved.

The climate, during the months of May and June, or the beginning of winter, was delightful. The mean temperature, from observations taken at nine o'clock, both morning and evening, was only $72^{\lrcorner}$. It often rained heavily, but the drying southerly winds soon again rendered the walks pleasant. One morning, in the course of six hours, 1.6 inches of rain fell. As this storm passed over the forests which surround the Corcovado, the sound produced by the drops pattering on the countless multitude of leaves was very remarkable; it could be heard at the distance of a quarter of a mile, and was like the rushing of a great body of water. After the hotter days, it was delicious to sit quietly in the garden and watch the evening pass into night. Nature, in these climes, chooses her vocalists from more humble performers than in Europe. A small frog, of the genus Hyla, sits on a blade of grass about an inch above the surface of the water, and sends forth a pleasing chirp: when several are together they sing in harmony on different notes. I had some difficulty in catching a specimen of this frog. The genus Hyla has its toes terminated by small suckers; and I found this animal could crawl up a pane of glass, when placed absolutely perpendicular. Various cicadæ and crickets, at the same time, keep up a ceaseless shrill cry, but which, softened by the distance, is not unpleasant. Every evening after dark this great concert commenced; and often have I sat listening to it, until my attention has been drawn away by some curious passing insect.

At these times the fireflies are seen flitting about from hedge to hedge. On a dark night the light can be seen at about two hundred paces distant. It is remarkable that in all the different kinds of glowworms, shining elaters, and various marine animals 
(such as the crustacea, medusæ, nereidæ, a coralline of the genus Clytia, and Pyrosoma), which I have observed, the light has been of a well-marked green colour. All the fireflies, which I caught here, belonged to the Lampyridæe (in which family the English glowworm is included), and the greater number of specimens were of Lampyris occidentalis. ${ }^{*}$ I found that this insect emitted the most brilliant flashes when irritated : in the intervals, the abdominal rings were obscured. The flash was almost coinstantaneous in the two rings, but it was just perceptible first in the anterior one. The shining matter was fluid and very adhesive: little spots, where the skin had been torn, continued bright with a slight scintillation, whilst the uninjured parts were obscured. When the insect was decapitated the rings remained uninterruptedly bright, but not so brilliant as before: local irritation with a needle always increased the vividness of the light. The rings in one instance retained their luminous property nearly twenty-four hours after the death of the insect. From these facts it would appear probable, that the animal has only the power of concealing or extinguishing the light for short intervals, and that at other times the display is involuntary. On the muddy and wet gravel-walks I found the larvæ of this lampyris in great numbers : they resembled in general form the female of the English glowworm. These larvæ possessed but feeble luminous powers; very differently from their parents, on the slightest touch they feigned death, and ceased to shine; nor did irritation excite any fresh display. I kept several of them alive for some time: their tails are very singular organs, for they act, by a well-fitted contrivance, as suckers or organs of attachment, and likewise as reservoirs for saliva, or some such fluid. I repeatedly fed them on raw meat; and $I$ invariably observed, that every now and then the extremity of the tail was applied to the mouth, and a drop of fluid exuded on the meat, which was then in the act of being consumed. The tail, notwithstanding so much practice, does not seem to be able to find its way to the mouth; at least the neck was always touched first, and apparently as a guide.

* I am greatly indebted to Mr. Waterhouse for his kindness in naming for me this and many other insects, and in giving me much valuable assist-
ance. 
When we were at Bahia, an elater or beetle (Pyrophorus luminosus, Illig.) seemed the most common luminous insect. The light in this case was also rendered more brilliant by irritation. I amused myself one day by observing the springing powers of this insect, which have not, as it appears to me, been properly described.* The elater, when placed on its back and preparing to spring, moved its head and thorax backwards, so that the pectoral spine was drawn out, and rested on the edge of its sheath. The same backward movement being continued, the spine, by the full action of the muscles, was bent like a spring; and the insect at this moment rested on the extremity of its head and wing-cases. The effort being suddenly relaxed, the head and thorax flew up, and in consequence, the base of the wingcases struck the supporting surface with such force, that the insect by the reaction was jerked upwards to the height of one or two inches. The projecting points of the thorax, and the sheath of the spine, served to steady the whole body during the spring. In the descriptions which I have read, sufficient stress does not appear to have been laid on the elasticity of the spine: so sudden a spring could not be the result of simple muscular contraction, without the aid of some mechanical contrivance.

On several occasions I enjoyed some short but most pleasant excursions in the neighbouring country. One day I went to the Botanic Garden, where many plants, well known for their great utility, might be seen growing. The leaves of the camphor, pepper, cinnamon, and clove trees were delightfully aromatic; and the bread-fruit, the jaca, and the mango, vied with each other in the magnificence of their foliage. The landscape in the neighbourhood of Bahia almost takes its character from the two latter trees. Before seeing them, I had no idea that any trees could cast so black a shade on the ground. Both of them bear to the evergreen vegetation of these climates the same kind of relation which laurels and hollies in England do to the lighter green of the deciduous trees. It may be observed, that the houses within the tropics are surrounded by the most beautiful forms of vegetation, because many of them are at the same

* Kirby's Entomology, vol. ii., p. 317. 
time most useful to man. Who can doubt that these qualities are united in the banana, the cocoa-nut, the many kinds of palm, the orange, and the bread-fruit tree?

During this day I was particularly struck with a remark of Humboldt's, who often alludes to "the thin vapour which, without changing the transparency of the air, renders its tints more harmonious, and softens its effects." This is an appearance which I have never observed in the temperate zones. The atmosphere, seen through a short space of half or three quarters of a mile, was perfectly lucid, but at a greater distance all colours were blended into a most beautiful haze, of a pale French grey, mingled with a little blue. The condition of the atmosphere between the morning and about noon, when the effect was most evident, had undergone little change, excepting in its dryness. In the interval, the difference between the dew point and temperature had increased from $7^{\circ} .5$ to $17^{\circ}$.

On another occasion I started early and walked to the Gavia, or topsail mountain. The air was delightfully cool and fragrant; and the drops of dew still glittered on the leaves of the large liliaceous plants, which shaded the streamlets of clear water. Sitting down on a block of granite, it was delightful to watch the various insects and birds as they flew past. The humming-bird seems particularly fond of such shady retired spots. Whenever I saw these little creatures buzzing round a flower, with their wings vibrating so rapidly as to be scarcely visible, I was reminded of the sphinx moths: their movements and habits are indeed in many respects very similar.

Following a pathway I entered a noble forest, and from a height of five or six hundred feet, one of those splendid views was presented, which are so common on every side of Rio. At this elevation the landscape attains its most brilliant tint; and every form, every shade, so completely surpasses in magnificence all that the European has ever beheld in his own country, that he knows not how to express his feelings. The general effect frequently recalled to my mind the gayest scenery of the Operahouse or the great theatres. I never returned from these excursions empty handed. This day $\mathrm{I}$ found a specimen of a curious fungus, called Hymenophallus. Most people know the English Phallus, which in autumn taints the air with its odious smell: 
this, however, as the entomologist is aware, is to some of our beetles a delightful fragrance. So was it here; for a Strongylus, attracted by the odour, alighted on the fungus as I carried it in my hand. We here see in two distant countries a similar relation between plants and insects of the same families, though the species of both are different. When man is the agent in introducing into a country a new species, this relation is often broken: as one instance of this I may mention, that the leaves of the cabbages and lettuces, which in England afford food to such a multitude of slugs and caterpillars, in the gardens near Rio are untouched.

During our stay at Brazil I made a large collection of insects. A few general observations on the comparative importance of the different orders may be interesting to the English entomologist. The large and brilliantly-coloured Lepidoptera bespeak the zone they inhabit, far more plainly than any other race of animals. I allude only to the butterflies; for the moths, contrary to what might have been expected from the rankness of the vegetation, certainly appeared in much fewer numbers than in our own temperate regions. I was much surprised at the habits of Papilio feronia. 'This butterfly is not uncommon, and generally frequents the orange-groves. Although a high flier, yet it very frequently alights on the trunks of trees. On these occasions its head is invariably placed downwards ; and its wings are expanded in a horizontal plane, instead of being folded vertically, as is commonly the case. This is the only butterfly which I have ever seen, that uses its legs for running. Not being aware of this fact, the insect, more than once, as I cautiously approached with my forceps, shuffled on one side just as the instrument was on the point of closing, and thus escaped. But a far more singular fact is the power which this species possesses of making a noise.* Several times when a pair, probably male

* Mr. Doubleday has lately described (before the Entomological Society, March 3rd, 1845) a peculiar structure in the wings of this butterfly, which seems to be the means of its making its noise. He says, "It is remarkable for having a sort of drum at the base of the fore wings, between the costal nervure and the subcostal. These two nervures, moreover, have a peculiar screw-like diaphragm or vessel in the interior." I find in Langsdorff's travels (in the years $1803-7$, p. 74) it is said. that in the island of St. Catherine's on the coast of Brazil, a butterfly called Februa Hoffmanseggi, makes a noise, when flying away, like a rattle. 
and female, were chasing each other in an irregular course, they passed within a few yards of me; and I distinctly heard a elicking noise, similar to that produced by a toothed wheel passing under a spring catch. The noise was continued at short intervals, and could be distinguished at about twenty yards' distance: I am certain there is no error in the observation.

I was disappointed in the general aspect of the Coleoptera. The number of minute and obscurely-coloured beetles is exceedingly great.* The cabinets of Europe can, as yet, boast only of the larger species from tropical climates. It is sufficient to disturb the composure of an entomologist's mind, to look forward to the future dimensions of a complete catalogue. 'The carnivorous beetles, or Carabidæ, appear in extremely few numbers within the tropics: this is the more remarkable when compared to the case of the carnivorous quadrupeds, which are so abundant in hot countries. I was struck with this observation both on entering Brazil, and when I saw the many elegant and active forms of the Harpalidæ re-appearing on the temperate plains of La Plata. Do the very numerous spiders and rapacious Hymenoptera supply the place of the carnivorous beetles? The carrion-feeders and Brachelytera are very uncommon; on the other hand, the Rhyncophora and Chrysomelidæ, all of which depend on the vegetable world for subsistence, are present in astonishing numbers. I do not here refer to the number of different species, but to that of the individual insects; for on this it is that the most striking eharacter in the entomology of different countries depends. The orders Orthoptera and Hemiptera are particularly numerous; as likewise is the stinging division of the Hymenoptera; the bees, perhaps, being excepted. A person, on first entering a tropical forest, is astonished at the labours of the ants : well-beaten paths branch off in every direction, on which an army of never-failing foragers may be seen, some going forth,

* I may mention, as a common instance of one day's (June $23 \mathrm{r}$ d) collecting, when I was not attending particularly to the Coleoptera, that I caught sixty-eight species of that order. Among these, there were only two of the Carabidæ, four Brachelytra, fifteen Rhyncophora, and fourteen of the Chrysomelidæ. Thirty-seven species of Arachnidæ, which I brought home, will be sufficient to prove that I was not paying overmuch attention to the generally favoured order of Coleoptera. 
and others returning, burdened with pieces of green leaf, often larger than their own bodies.

A small dark-coloured ant sometimes migrates in countless numbers. One day, at Bahia, my attention was drawn by observing many spiders, cockroaches, and other insects, and some lizards, rushing in the greatest agitation across a bare piece of ground. A little way behind, every stalk and leaf was blackened by a small ant. The swarm having crossed the bare space, divided itself, and descended an old wall. By this means many insects were fairly enclosed; and the efforts which the poor little creatures made to extricate themselves from such a death were wonderful. When the ants came to the road they changed their course, and in narrow files reascended the wall. Having placed a small stone so as to intercept one of the lines, the whole body attacked it, and then immediately retired. Shortly afterwards another body came to the charge, and again having failed to make any impression, this line of march was entirely given up. By going an inch round, the file might have avoided the stone, and this doubtless would have happened, if it had been originally there : but having been attacked, the lion-hearted little warriors scorned the idea of yielding.

Certain wasp-like insects, which construct in the corners of the verandahs clay cells for their larvæ, are very numerous in the neighbourhood of Rio. These cells they stuff full of half-dead spiders and caterpillars, which they seem wonderfully to know how to sting to that degree as to leave them paralysed but alive, until their eggs are hatched; and the larva feed on the horrid mass of powerless, half-killed victims-a sight which has been described by an enthusiastic naturalist* as curious and pleasing ! I was much interested one day by watching a deadly contest between a Pepsis and a large spider of the genus Lycosa. The wasp made a sudden dash at its prey, and then flew away: the spider was evidently wounded, for, trying to escape, it rolled down a little slope, but had still strength sufficient to crawl into a thick tuft of grass. The wasp soon returned, and seemed sur-

* In a MS. in the British Museum by Mr. Abbott, who made his observations in Georgia; see Mr. A. White's paper in the 'Annals of Nat. Hist.,' vol. vii. p. 472. Lieut. Hutton has described a sphex with similar habits in India, in the 'Journal of the Asiatic Society,' vol. i., p. 555. 
prised at not immediately finding its victim. It then commenced as regular a hunt as ever hound did after fox; making short semicircular casts, and all the time rapidly vibrating its wings and antennæ. The spider, though well concealed, was soon aiscovered; and the wasp, evidently still afraid of its adversary's jaws, after much manœuvring, inflicted two stings on the under side of its thorax. At last, carefully examining with its antennæ the now motionless spider, it proceeded to drag away the body. But I stopped both tyrant and prey.*

The number of spiders, in proportion to other insects, is here compared with England very much larger; perhaps more so than with any other division of the articulate animals. The variety of species among the jumping spiders appears almost infinite. The genus, or rather family of Epeira, is here characterized by many singular forms; some species have pointed coriaceous shells, others enlarged and spiny tibiæ. Every path in the forest is barricaded with the strong yellow web of a species, belonging to the same division with the Epeira clavipes of $\mathrm{Fa}$ bricius, which was formerly said by Sloane to make, in the West Indies, webs so strong as to catch birds. A small and pretty kind of spider, with very long fore-legs, and which appears to belong to an undescribed genus, lives as a parasite on almost every one of these webs. I suppose it is too insignificant to be noticed by the great Epeira, and is therefore allowed to prey on the minute insects, which, adhering to the lines, would, otherwise be wasted. When frightened, this little spider either feigns death by extending its front legs, or suddenly drops from the web. A large Epeira of the same division with Epeira tuberculata and conica is extremely common, especially in dry situations. Its web, which is generally placed among the great leaves of the common agave, is sometimes strengthened near the centre by a pair or even four zigzag ribbons, which connect two adjoining rays. When any large insect, as a grasshopper or wasp, is caught, the spider, by a dexterous movement, makes it revolve very rapidly, and at the same time emitting a band of threads

* Don Felix Azara (vol. i., p. 175), mentioning a hymenopterous insect, probably of the same genus, says, he saw it dragging a dead spider through tall grass, in a straight line to its nest, which was one hundred and sixtythree paces distant. He adds that the wasp, in order to find the road, every now and then made "demi-tours d'environ trois palmes." 
from its spinners, soon envelops its prey in a case like the cocoon of a silkworm. The spider now examines the powerless victim, and gives the fatal bite on the hinder part of its thorax; then retreating, patiently waits till the poison has taken effect. The virulence of this poison may be judged of from the fact that in half a minute I opened the mesh, and found a large wasp quite lifeless. This Epeira always stands with its head downwards near the centre of the web. When disturbed, it acts differently according to circumstances : if there is a thicket below, it suddenly falls down; and I have distinctly seen the thread from the spinners lengthened by the animal while yet stationary, as preparatory to its fall. If the ground is clear beneath, the Epeira seldom falls, but moves quickly through a central passage from one to the other side. When still further disturbed, it practises E most curious manœuvre: standing in the middle, it violently jerks the web, which is attached to elastic twigs, till at last the whole acquires such a rapid vibratory movement, that even the outline of the spider's body becomes indistinct.

It is well known that most of the British spiders, when a large insect is caught in their webs, endeavour to cut the lines and liberate their prey, to save their nets from being entirely spoiled. I once, however, saw in a hot-house in Shropshire a large female wasp caught in the irregular web of a quite small spider; and this spider, instead of cutting the web, most perseveringly continued to entangle the body, and especially the wings, of its prey. The wasp at first aimed in vain repeated thrusts with its sting at its little antagonist. Pitying the wasp, after allowing it to struggle for more than an hour, I killed it and put it back into the web. The spider soon returned; and an hour afterwards I was much surprised to find it with its jaws buried in the orifice, through which the sting is protruded by the living wasp. I drove the spider away two or three times, but for the next twenty-four hours I always found it again sucking at the same place. The spider became much distended by the juices of its prey, which was many times larger than itself.

I may here just mention, that I found, near St. Fé Bajada, many large black spiders, with ruby-coloured marks on their backs, having gregarious habits. The webs were placed verti- 
cally, as is invariably the case with the genus Epeira: they were separated from each other by a space of about two feet, but were all attached to certain common lines, which were of great length, and extended to all parts of the community. In this manner the tops of some large bushes were encompassed by the united nets. Azara* has described a gregarious spider in Paraguay, which Walckenaer thinks must be a Theridion, but probably it is an Epeira, and perhaps even the same species with mine. I cannot, however, recollect seeing a central nest as large as a hat, in which, during autumn, when the spiders die, Azara says the eggs are deposited. As all the spiders which I saw were of the same size, they must have been nearly of the same age. This gregarious habit, in so typical a genus as Epeira, among insects, which are so bloodthirsty and solitary that even the two sexes attack each other, is a very singular fact.

In a lofty valley of the Cordillera, near Mendoza, I found another spider with a singularly-formed web. Strong lines radiated in a vertical plane from a common centre, where the insect had its station; but only two of the rays were connected by a symmetrical mesh-work; so that the net, instead of being, as is generally the case, circular, consisted of a wedge-shaped segment. All the webs were similarly constructed.

- Azara's Voyage, vol, i., p. 213. 


\section{CHAPTER III.}

Monte Video-Maldonado-Excursion to R. Polanco-Lazo and BolasPartridges-Absence of Trees-Deer-Capybara, or River Hog-Tucutuco-Molothrus, cuckoo-like habits-Tyrant-flycatcher-Mocking-bird -Carrion Hawks-Tubes formed by Lightning-House struck.

\section{MALDONADO.}

July 5th, 1832.-IN the morning we got under way, and stood out of the splendid harbour of Rio de Janeiro. In our passage to the Plata, we saw nothing particular, excepting on one day a great shoal of porpoises, many hundreds in number. The whole sea was in places furrowed by them; and a most extraordinary spectacle was presented, as hundreds, proceeding together by jumps, in which their whole bodies were exposed, thus cut the water. When the ship was running nine knots an hour, these animals could cross and recross the bows with the greatest ease, and then dash away right ahead. As soon as we entered the estuary of the Plata, the weather was very uusettled. One dark night we were surrounded by numerous seals and penguins, which made such strange noises, that the officer on watch reported he could hear the cattle bellowing on shore. On a second night we witnessed a splendid scene of natural fireworks; the mast-head and yard-arm-ends shone with St. Elmo's light; and the form of the vane could almost be traced, as if it had been rubbed with phosphorus. The sea was so highly luminous, that the tracks of the penguins were marked by a fiery wake, and the darkness of the sky was momentarily illuminated by the most vivid lightning.

When within the mouth of the river, I was interested by observing how slowly the waters of the sea and river mixed. The latter, muddy and discoloured, from its less specific gravity, floated on the surface of the salt water. This was curiously exhibited in the wake of the vessel, where a line of blue water was seen mingling in little eddies, with the adjoining fluid. 
July 26th.-We anchored at Monte Video. The Beagle was employed in surveying the extreme southern and eastern coasts of America, south of the Plata, during the two succeeding years. To prevent useless repetitions, I will extract those parts of my journal which refer to the same districts, without always attending to the order in which we visited them.

Maldonado is situated on the northern bank of the Plata, and not very far from the mouth of the estuary. It is a most quiet, forlorn, little town; built, as is universally the case in these countries, with the streets running at right angles to each other, and having in the middle a large plaza or square, which, from its size, renders the scantiness of the population more evident. It possesses scarcely any trade; the exports being confined to a few hides and living cattle. The inhabitants are chiefly landowners, together with a few shopkeepers and the necessary tradesmen, such as blacksmiths and carpenters, who do nearly all the business for a circuit of fifty miles round. The town is separated from the river by a band of sand-hillocks, about a mile broad: it is surrounded, on all other sides, by an open slightlyundulating country, covered by one uniform layer of fine green turf, on which countless herds of cattle, sheep, and horses graze. There is very little land cultivated even close to the town. A few hedges, made of cacti and agave, mark out where some wheat or Indian corn has been planted. The features of the country are very similar along the whole northern bank of the Plata. The only difference is, that here the granitic hills are a little bolder. The scenery is very uninteresting; there is scarcely a house, an enclosed piece of ground, or even a tree, to give it an air of cheerfulness. Yet, after being imprisoned for some time in a ship, there is a charm in the unconfined feeling of walking over boundless plains of turf. Moreover, if your view is limited to a small space, many objects possess beauty. Some of the smaller birds are brilliantly coloured; and the bright green sward, browsed short by the cattle, is ornamented by dwarf flowers, among which a plant, looking like the daisy, claimed the place of an old friend. What would a florist say to whole tracts so thickly covered by the Verbena melindres, as, even at a distance, to appear of the most gaudy scarlet?

I staid ten weeks at Maldonado, in which time a nearly perfect 
collection of the animals, birds, and reptiles, was procured. Before making any observations respecting them, I will give an account of a little excursion I made as far as the river Polanco, which is about seventy miles distant, in a northerly direction. I may mention, as a proof how cheap everything is in this country, that I paid only two dollars a day, or eight shillings, for two men, together with a troop of about a dozen ridinghorses. My companions were well armed with pistols and sabres; a precaution which I thought rather unnecessary; but the first piece of news we heard was, that, the day before, a traveller from Monte Video had been found dead on the road, with his throat cut. This happened close to a cross, the record of a former murder.

On the first night we slept at a retired little country-house; and there I soon found out that I possessed two or three articles, especially a pocket compass, which created unbounded astonishment. In every house I was asked to show the compass, and by its aid, together with a map, to point out the direction of various places. It excited the liveliest admiration that I, a perfect stranger, should know the road (for direction and road are synonymous in this open country) to places where I had never been. At one house a young woman, who was ill in bed, sent to entreat me to come and show her the compass. If their surprise was great, mine was greater, to find such ignorance among people who possessed their thousands of cattle, and " estancias" of great extent. It can only be accounted for by the circumstance that this retired part of the country is seldom visited by foreigners. I was asked whether the earth or sun moved; whether it was hotter or colder to the north; where Spain was, and many other such questions. The greater number of the inhabitants had an indistinct idea that England, London, and North America, were different names for the same place; but the better informed well knew that London and North America were separate countries close together, and that England was a large town in London! I carried with me some promethean matches, which I ignited by biting; it was thought so wonderful that a man should strike fire with his teeth, that it was usual to collect the whole family to see it: I was once offered a dollar for a single one. Washing my face in the morning caused much speculation at the village 
of Las Minas; a superior tradesman closely cross-questioned me about so singular a practice; and likewise why on board we wore our beards; for he had heard from my guide that we did so. He eyed me with much suspicion; perhaps he had heard of ablutions in the Mahomedan religion, and knowing me to be a heretick, probably he came to the conclusion that all hereticks were Turks. It is the general custom in this country to ask for a night's lodging at the first convenient house. The astonishment at the compass, and my other feats in jugglery, was to a certain degree advantageous, as with that, and the long stories my guides told of my breaking stones, knowing venomous from harmless snakes, collecting insects, \&c., I repaid them for their hospitality. I am writing as if I had been among the inhabitants of central Africa: Banda Oriental would not be flattered by the comparison; but such were my feelings at the time.

The next day we rode to the village of Las Minas. The country was rather more hilly, but otherwise continued the same; an inhabitant of the Pampas no doubt would have considered it as truly Alpine. The country is so thinly inhabited, that during the whole day we scarcely met a single person. Las Minas is much smaller even than Maldonado. It is seated on a little plain, and is surrounded by low rocky mountains. It is of the usual symmetrical form; and with its whitewashed church standing in the centre, had rather a pretty appearance. The outskirting houses rose out of the plain like isolated beings, without the accompaniment of gardens or courtyards. This is generally the case in the country, and all the houses have, in consequence, an uncomfortable aspect. At night we stopped at a pulperia, or drinking-shop. During the evening a great number of Gauchos came in to drink spirits and smoke cigars : their appearance is very striking; they are generally tall and handsome, but with a proud and dissolute expression of countenance. They frequently wear their moustaches, and long black hair curling down their backs. With their brightly-coloured garments, great spurs clanking about their heels, and knives stuck as daggers (and often so used) at their waists, they look a very different race of men from what might be expected from their name of Gauchos, or simple countrymen. Their politeness is excessive; they never drink their spirits without expecting you 
to taste it; but whilst making their exceedingly graceful bow, they seem quite as ready, if occasion offered, to cut your throat.

On the third day we pursued rather an irregular course, as I was employed in examining some beds of marble. On the fine plains of turf we saw many ostriches (Struthio rhea). Some of the flocks contained as many as twenty or thirty birds. These, when standing on any little eminence, and seen against the clear sky, presented a very noble appearance. I never met with such tame ostriches in any other part of the country: it was easy to gallop up within a short distance of them; but then, expanding their wings, they made all sail right before the wind, and soon left the horse astern.

At night we came to the house of Don Juan Fuentes, a rich landed proprietor, but not personally known to either of my companions. On approaching the house of a stranger, it is usual to follow several little points of etiquette: riding up slowly to the door, the salutation of Ave Maria is given, and until somebody comes out and asks you to alight, it is not customary even to get off your horse: the formal answer of the owner is, "sin pecado concebida"-that is, conceived without sin. Having entered the house, some general conversation is kept up for a few minutes, till permission is asked to pass the night there. This is granted as a matter of course. The stranger then takes his meals with the family, and a room is assigned him, where with the horsecloths belonging to his recado (or saddle of the Pampas) he makes his bed. It is curious how similar circumstances produce such similar results in manners. At the Cape of Good Hope the same hospitality, and very nearly the same points of etiquette, are universally observed. The difference, however, between the character of the Spaniard and that of the Dutch boor is shown, by the former never asking his guest a single question beyond the strictest rule of politeness, whilst the honest Dutchman demands where he has been, where he is going, what is his business, and even how many brothers, sisters, or children he may happen to have.

Shortly after our arrival at Don Juan's, one of the large herds of cattle was driven in towards the house, and three beasts were picked out to be slaughtered for the supply of the establishment. These half-wild cattle are very active; and knowing full well 
the fatal lazo, they led the horses a long and laborious chase. After witnessing the rude wealth displayed in the number of cattle, men, and horses, Don Juan's miserable house was quite curious. The floor consisted of hardened mud, and the windows were without glass; the sitting-room boasted only of a few of the roughest chairs and stools, with a couple of tables. The supper, although several strangers were present, consisted of two huge piles, one of roast beef, the other of boiled, with some pieces of pumpkin: besides this latter there was no other vegetable, and not even a morsel of bread. For drinking, a large earthenware jug of water served the whole party. Yet this man was the owner of several square miles of land, of which nearly every acre would produce corn, and, with a little trouble, all the common vegetables. The evening was spent in smoking, with a little impromptu singing, accompanied by the guitar. The signoritas all sat together in one corner of the room, and did not sup with the men.

So many works have been written about these countries, that it is almost superfluous to describe either the lazo or the bolas. The lazo consists of a very strong, but thin, well-plaited rope, made of raw hide. One end is attached to the broad surcingle, which fastens together the complicated gear of the recado, or saddle used in the Pampas; the other is terminated by a small ring of iron or brass, by which a noose can be formed. The Gaucho, when he is going to use the lazo, keeps a small coil in his bridle-hand, and in the other holds the running noose, which is made very large, generally having a diameter of about eight feet. This he whirls round his head, and by the dexterous movement of his wrist keeps the noose open; then, throwing it, he causes it to fall on any particular spot he chooses. The lazo, when not used, is tied up in a small coil to the after part of the recado. The bolas, or balls, are of two kinds: the simplest, which is chiefly used for catching ostriches, consists of two round stones, covered with leather, and united by a thin plaited thong, about eight feet long. The other kind differs only in having three balls united by the thongs to a common centre. The Gaucho holds the smallest of the three in his hand, and whirls the other two round and round his head; then, taking aim, sends them like chain shot revolving through the air. The 
balls no sooner strike any object, than, winding round it, they cross each other, and become firmly hitched. The size and weight of the balls varies, according to the purpose for which they are made: when of stone, although not larger than an apple, they are sent with such force as sometimes to break the leg even of a horse. I have seen the balls made of wood, and as large as a turnip, for the sake of catching these animals without injuring them. The balls are sometimes made of iron, and these can be hurled to the greatest distance. The main difficulty in using either lazo or bolas is to ride so well as to be able at full speed, and while suddenly turning about, to whirl them so steadily round the head, as to take aim: on foot any person would soon learn the art. One day, as I was amusing myself by galloping and whirling the balls round my head, by accident the free one struck a bush; and its revolving motion being thus destroyed, it immediately fell to the ground, and like magic caught one hind leg of my horse; the other ball was then jerked out of my hand, and the horse fairly secured. Luckily he was an old practised animal, and knew what it meant; otherwise he would probably have kicked till he had thrown himself down. The Gauchos roared with laughter; they cried out that they had seen every sort of animal caught, but had never before seen a man caught by himself.

During the two succeeding days, I reached the furthest point which I was anxious to examine. The country wore the same aspect, till at last the fine green turf became more wearisome than a dusty turnpike road. We everywhere saw great numbers of partridges (Nothura major). These birds do not go in coveys, nor do they conceal themselves like the English kind. It appears a very silly bird. A man on horseback by riding round and round in a circle, or rather in a spire, so as to approach closer each time, may knock on the head as many as he pleases. The more common method is to catch them with a running noose, or little lazo, made of the stem of an ostrich's feather, fastened to the end of a long stick. A boy on a quiet old horse will frequently thus catch thirty or forty in a day. In Arctic North America* the Indians catch the Varying Hare by walking spirally

- Hearne's Journey, p. 383. 
round and round it, when on its form : the middle of the day is reckoned the best time, when the sun is high, and the shadow of the hunter not very long.

On our return to Maldonado, we followed rather a different line of road. Near Pan de Azucar, a landmark well known to all those who have sailed up the Plata, I stayed a day at the house of a most hospitable old Spaniard. Early in the morning we ascended the Sierra de las Animas. By the aid of the rising sun the scenery was almost picturesque. To the westward the view extended over an immense level plain as far as the Mount, at Monte Video, and to the eastward, over the mammillated country of Maldonado. On the summit of the mountain there were several small heaps of stones, which evidently had lain there for many years. My companion assured me that they were the work of the Indians in the old time. The heaps were similar, but on a much smaller scale, to those so commonly found on the mountains of Wales. The desire to signalize any event, on the highest point of the neighbouring land, seems an universal passion with mankind. At the present day, not a single Indian, either civilized or wild, exists in this part of the province; nor am I aware that the former inhabitants have left behind them any more permanent records than these insignificant piles on the summit of the Sierra de las Animas.

The general, and almost entire absence of trees in Banda Oriental is remarkable. Some of the rocky hills are partly covered by thickets, and on the banks of the larger streams, especially to the north of Las Minas, willow-trees are not uncommon. Near the Arroyo Tapes I heard of a wood of palms; and one of these trees, of considerable size, I saw near the Pan de Azucar, in lat. $35^{\circ}$. These, and the trees planted by the Spaniards, offer the only exceptions to the general scarcity of wood. Among the introduced kinds may be enumerated poplars, olives, peach, and other fruit trees: the peaches succeed so well, that they afford the main supply of firewood to the city of Buenos Ayres. Extremely level countries, such as the Pampas, seldom appear favourable to the growth of trees. This may possibly be attributed either to the force of the winds, or the kind of drainage. In the nature of the land, however, around Maldonado, no such 
reason is apparent; the rocky mountains afford protected situations, enjoying various kinds of soil; streamlets of water are common at the bottoms of nearly every valley; and the clayey nature of the earth seems adapted to retain moisture. It has been inferred with much probability, that the presence of woodland is generally determined* by the annual amount of moisture; yet in this province abundant and heavy rain falls during the winter; and the summer, though dry, is not so in any excessive degree. $\dagger$ We see nearly the whole of Australia covered by lofty trees, yet that country possesses a far more arid climate. Hence we must look to some other and unknown cause.

Confining our view to South America, we should certainly be tempted to believe that trees flourished only under a very humid climate; for the limit of the forest-land follows, in a most remarkable manner, that of the damp winds. In the southern part of the continent, where the western gales, charged with moisture from the Pacific, prevail, every island on the broken west coast, from lat. $38^{\circ}$ to the extreme point of Tierra del Fuego, is densely covered by impenetrable forests. On the eastern side of the Cordillera, over the same extent of latitude, where a blue sky and a fine climate prove that the atmosphere has been deprived of its moisture by passing over the mountains, the arid plains of Patagonia support a most scanty vegetation. In the more northern parts of the continent, within the limits of the constant south-eastern trade wind, the eastern side is ornamented by magnificent forests; whilst the western coast, from lat. $4^{\circ} \mathrm{S}$. to lat. $32^{\circ}$ S., may be described as a desert: on this western coast, northward of lat. $4^{\circ} \mathrm{S}$., where the trade-wind loses its regularity, and heavy torrents of rain fall periodically, the shores of the Pacific, so utterly desert in Peru, assume near Cape Blanco the character of luxuriance so celebrated at Guyaquil and Panama. Hence in the southern and northern parts of the continent, the forest and desert lands occupy reversed positions with respect to the Cordillera, and these positions are apparently determined by the direction of the prevalent winds. In the middle of the continent there is a broad intermediate band, including

* Maclaren, art. " America,' Encyclop. Britann.

† Azara says, "Je crois que la quantité annuelle des pluies est, dans toutes ces contrées, plus considérable qu en Espagae."-Vol. i. p. 36. 
central Chile and the provinces of $\mathrm{La}$ Plata, where the rainbringing winds have not to pass over lofty mountains, and where the land is neither a desert nor covered by forests. But even the rule, if confined to South America, of trees flourishing only in a climate rendered humid by rain-bearing winds, has a strongly marked exception in the case of the Falkland Islands. These islands, situated in the same latitude with Tierra del Fuego and only between two and three hundred miles distant from it, having a nearly similar climate, with a geological formation almost identical, with favourable situations and the same kind of peaty soil, yet can boast of few plants deserving even the title of bushes; whilst in Tierra del Fuego it is impossible to find an acre of land not covered by the densest forest. In this case, both the direction of the heavy gales of wind and of the currents of the sea are favourable to the transport of seeds from Tierra del Fuego, as is shown by the canoes and trunks of trees drifted from that country, and frequently thrown on the shores of the Western Falkland. Hence perhaps it is, that there are many plants in common to the two countries: but with respect to the trees of Tierra del Fuego, even attempts made to transplant them have failed.

During our stay at Maldonado I collected several quadrupeds, eighty kinds of birds, and many reptiles, including nine species of snakes. Of the indigenous mammalia, the only one now left of any size, which is common, is the Cervus campestris. This deer is exceedingly abundant, often in small herds, throughout the countries bordering the Plata and in Northern Patagonia. If a person crawling close along the ground, slowly advances towards a herd, the deer frequently, out of curiosity, approach to reconnoitre him. I have by this means killed, from one spot, three out of the same herd. Although so tame and inquisitive, yet when approached on horseback, they are exceedingly wary. In this country nobody goes on foot, and the deer knows man as its enemy only when he is mounted and armed with the bolas. At Bahia Blanca, a recent establishment in Northern Patagonia, I was surprised to find how little the deer cared for the noise of a gun: one day I fired ten times from within eighty yards at one animal; and it was much more startled at the ball cutting up the ground than at the report of 
the rifle. My powder being exhausted, I was obliged to get up (to my shame as a sportsman be it spoken, though well able to kill birds on the wing) and halloo till the deer ran away.

The most curious fact with respect to this animal, is the overpoweringly strong and offensive odour which proceeds from the buck. It is quite indescribable: several times whilst skinning the specimen which is now mounted at the Zoological Museum, I was almost overcome by nausea. I tied up the skin in a silk pocket-handkerchief, and so carried it home : this handkerchief, after being well washed, I continually used, and it was of course as repeatedly washed; yet every time, for a space of one year and seven months, when first unfolded, I distinctly perceived the odour. This appears an astonishing instance of the permanence of some matter, which nevertheless in its nature must be most subtile and volatile. Frequently, when passing at the distance of half a mile to leeward of a herd, I have perceived the whole air tainted with the effluvium. I believe the smell from the buck is most powerful at the period when its horns are perfect, or free from the hairy skin. When in this state the meat is, of course, quite uneatable; but the Gauchos assert, that if buried for some time in fresh earth, the taint is removed. I have somewhere read that the islanders in the north of Scotland treat the rank carcasses of the fish-eating birds in the same manner.

The order Rodentia is here very numerous in species: of mice alone I obtained no less than eight kinds.* The largest gnawing animal in the world, the Hydrochærus capybara (the water-hog), is here also common. One which I shot at Monte Video weighed ninety-eight pounds: its length, from the end of the snout to the stump-like tail, was three feet two inches; and its girth three feet eight. These great Rodents occasionally frequent the islands in the mouth of the Plata, where the water is quite salt, but are far more abundant on the borders

* In South America I collected altogether twenty-seven species of mice; and thirteen more are known from the works of Azara and other authors. Those collected by myself have been named and described by Mr. Waterhouse at the meetings of the Zoological Society. I must be allowed to take this opportunity of returning my cordial thanks to Mr. Waterhouse, and to the other gentlemen attached to that Society, for their kind and most liberal assistance on all occasions. 
of fresh-water lakes and rivers. Near Maldonado three or four generally live together. In the daytime they either lie among the aquatic plants, or openly feed on the turf plain.* When viexed at a distance, from their manner of walking and colour they resemble pigs: but when seated on their haunches, and attentively watching any object with one eye, they reassume the appearance of their congeners, cavies and rabbits. Both the front and side view of their head has quite a ludicrous aspect, from the great depth of their jaw. These animals, at Maldonado, were very tame; by cautiously walking, I approached within three yards of four old ones. This tameness may probably be accounted for, by the Jaguar having been banished for some years, and by the Gaucho not thinking it worth his while to hunt them. As I approached nearer and nearer they frequently made their peculiar noise, which is a low abrupt grunt, not having much actual sound, but rather arising from the sudden expulsion of air: the only noise I know at all like it, is the first hoarse bark of a large dog. Having watched the four from almost within arm's length (and they me) for several minutes, they rushed into the water at full gallop with the greatest impetuosity, and emitted at the same time their bark. After diving a short distance they came again to the surface, but only just showed the upper part of their heads. When the female is swimming in the water, and has young ones, they are said to sit on her back. These animals are easily killed in numbers; but their skins are of trifling value, and the meat is very indifferent. On the islands in the Rio Parana they are exceedingly abundant, and afford the ordinary prey to the Jaguar.

The Tucutuco (Ctenomys Brasiliensis) is a curious small animal, which may be briefly described as a Gnawer, with the habits of a mole. It is extremely numerous in some parts of the country, but is difficult to be procured, and never, I believe, comes out of the ground. It throws up at the mouth of its

* In the stomach and duodenum of a capybara which I opened, I found a very large quantity of a thin yellowish fluid, in which scarcely a fibre could be distinguished. Mr. Owen informs me that a part of the cesophagus is so constructed that nothing much larger than a crowquill can be passed down. Certainly the broad teeth and strong jaws of this animal are well fitted to grind into pulp the aquatic plants on which it feeds. 
burrows hillocks of earth like those of the mole, but smaller. Considerable tracts of country are so completely undermined by these animals, that horses in passing over, sink above their fetlocks. 'The tucutucos appear, to a certain degree, to be gregarious: the man who procured the specimens for me had caught six together, and he said this was a common occurrence. They are nocturnal in their habits; and their principal food is the roots of plants, which are the object of their extensive and superficial burrows. This animal is universally known by a very peculiar noise which it makes when beneath the ground. A person, the first time he hears it, is much surprised; for it is not easy to tell whence it comes, nor is it possible to guess what kind of creature utters it. The noise consists in a short, but not rough, nasal grunt, which is monotonously repeated about four times in quick succession: ${ }^{*}$ the name Tucutuco is given in imitation of the sound. Where this animal is abundant, it may be heard at all times of the day, and sometimes directly beneath one's feet. When kept in a room, the tucutucos move both slowly and clumsily, which appears owing to the outward action of their hind legs; and they are quite incapable, from the socket of the thigh-bone not having a certain ligament, of jumping even the smallest vertical height. They are very stupid in making any attempt to escape; when angry or frightened they uttered the tucu-tuco. Of those I kept alive several, even the first day, became quite tame, not attempting to bite or to run away; others were a little wilder.

The man who caught them asserted that very many are invariably found blind. A specimen which I preserved in spirits was in this state; Mr. Reid considers it to be the effect of inflammation in the nictitating membrane. When the animal was alive I placed my finger within half an inch of its head, and not the slightest notice was taken: it made its way, however, about the room nearly as well as the others. Considering the strictly subterranean habits of the tucutuco, the blindness, though so

* At the R. Negro, in Northern Patagonia, there is an animal of the same habits, and probably a closely allied species, but which I never saw. Its noise is different from that of the Maldonado kind; it is repeated only twice instead of three or four times, and is more distinct and sonorous : when heard from a distance it so closely resembles the sound made in cutting down a small tree with an axe, that I have sometimes remained in doubt concerning it. 
common, cannot be a very serious evil; yet it appears strange that any animal should possess an organ frequently subject to be injured. Lamarck would have been delighted with this fact, had he known it, when speculating* (probably with more truth than usual with him) on the gradually-acquired blindness of the Aspalax, a Gnawer living under ground, and of the Proteus, a reptile living in dark caverns filled with water; in both of which animals the eye is in an almost rudimentary state, and is covered by a tendinous membrane and skin. In the common mole the eye is extraordinarily small but perfect, though many anatomists doubt whether it is connected with the true optic nerve; its vision must certainly be imperfect, though probably useful to the animal when it leaves its burrow. In the tucutuco, which I believe never comes to the surface of the ground, the eye is rather larger, but often rendered blind and useless, though without apparently causing any inconvenience to the animal: no doubt Lamarck would have said that the tucutuco is now passing into the state of the Aspalax and Proteus.

Birds of many kinds are extremely abundant on the undulating grassy plains around Maldonado. There are several species of a family allied in structure and manners to our Starling: one of these (Molothrus niger) is remarkable from its habits. Several may often be seen standing together on the back of a cow or horse ; and while perched on a hedge, pluming themselves in the sun, they sometimes attempt to sing, or rather to hiss ; the noise being very peculiar, resembling that of bubbles of air passing rapidly from a small orifice under water, so as to produce an acute sound. According to Azara, this bird, like the cuckoo, deposits its eggs in other birds' nests. I was several times told by the country people, that there certainly is some bird having this habit; and my assistant in collecting, who is a very accurate person, found a nest of the sparrow of this country (Zonotrichia matutina), with one egg in it larger than the others, and of a different colour and shape. In North America there is another species of Molothrus (M. pecoris), which has a similar cuckoolike habit, and which is most closely allied in every respect to the species from the Plata, even in such trifling peculiarities as

- Philosoph. Zoolog., tom. i. p. 242. 
standing on the backs of cattle; it differs only in being a little smaller, and in its plumage and eggs being of a slightly different shade of colour. This close agreement in structure and habits, in representative species coming from opposite quarters of a great continent, always strikes one as interesting, though of common occurrence.

Mr. Swainson has well remarked,* that with the exception of the Molothrus pecoris, to which must be added the M. niger, the cuckoos are the only birds which can be called truly parasitical ; namely, such as " fasten themselves, as it were, on another living animal, whose animal heat brings their young into life, whose food they live upon, and whose death would cause theirs during the period of infancy." It is remarkable that some of the species, but not all, both of the Cuckoo and Molothrus, should agree in this one strange habit of their parasitical propagation, whilst opposed to each other in almost every other habit: the molothrus, like our starling, is eminently sociable, and lives on the open plains without art or disguise : the cuckoo, as every one knows, is a singularly shy bird; it frequents the most retired thickets, and feeds on fruit and caterpillars. In structure also these two genera are widely removed from each other. Many theories, even phrenological theories, have been advanced to explain the origin of the cuckoo laying its eggs in other birds' nests. M. Prévost alone, I think, has thrown light by his observations $\dagger$ on this puzzle: he finds that the female cuckoo, which, according to most observers, lays at least from four to six eggs, must pair with the male each time after laying only one or two egg. Now, if the cuckoo was obliged to sit on her own eggs, she would either have to sit on all together, and therefore leave those first laid so long, that they probably would become addled; or she would have to hatch separately each egg or two eggs, as soon as laid: but as the cuckoo stays a shorter time in this country than any other migratory bird, she certainly would not have time enough for the successive hatchings. Hence we can perceive in the fact of the cuckoo pairing several times, and laying her eggs at intervals, the cause of her depositing her eggs in other birds' nests, and leaving them to the care of foster-

- Magazine of Zoology and Botany, vol. i. p. 217.

$\dagger$ Read before the Academy of Sciences in Paris. L'Institut, 1834, p. 418. 
parents. I am strongly inclined to believe that this view is correct, from having been independently led (as we shall hereafter see) to an analogous conclusion with regard to the South American ostrich, the females of which are parasitical, if I may so express it, on each other; each female laying several eggs in the nests of several other females, and the male ostrich undertaking all the cares of incubation, like the strange foster-parents with the cuckoo.

I will mention only two other birds, which are very common, and render themselves prominent from their habits. The Saurophagus sulphuratus is typical of the great American tribe of tyrant-flycatchers. In its structure it closely approaches the true shrikes, but in its habits may be compared to many birds. I have frequently observed it, hunting a field, hovering over one spot like a hawk, and then proceeding on to another. When seen thus suspended in the air, it might very readily at a short distance be mistaken for one of the Rapacious order; its stoop, however, is very inferior in force and rapidity to that of a hawk. At other times the Saurophagus haunts the neighbourhood of water, and there, like a kingfisher, remaining stationary, it catches any small fish which may come near the margin. These birds are not unfrequently kept either in cages or in courtyards, with their wings cut. They soon become tame, and are very amusing from their cunning odd manners, which were described to me as being similar to those of the common magpie. Their flight is undulatory, for the weight of the head and bill appear too great for the body. In the evening the Saurophagus takes its stand on a bush, often by the road-side, and continually repeats without change a shrill and rather agreeable cry, which somewhat resembles articulate words : the Spaniards say it is like the words "Bien te veo" (I see you well), and accordingly have given it this name.

A mocking-bird (Mimus orpheus), called by the inhabitants Calandria, is remarkable, from possessing a song far superior to that of any other bird in the country : indeed, it is nearly the only bird in South America which I have observed to take its stand for the purpose of singing. The song may be compared to that of the Sedge warbler, but is more powerful; some harsh notes and some very high ones, being mingled with a pleasant 
warbling. It is heard only during the spring. At other times its ery is harsh and far from harmonious. Near Maldonado these birds were tame and bold; they constantly attended the country houses in numbers, to pick the meat which was hung up on the posts or walls : if any other small bird joined the feast, the Calandria soon chased it away. On the wide uninhabited plains of Patagonia another closely allied species, O. Patagonica of d'Orbigny, which frequents the valleys clothed with spiny bushes, is a wilder bird, and has a slightly different tone of voice. It appears to me a curious circumstance, as showing the fine shades of difference in habits, that judging from this latter respect alone, when I first saw this second species, I thought it was different from the Maldonado kind. Having afterwards procured a specimen, and comparing the two without particular care, they appeared so very similar, that I changed my opinion; but now Mr. Gould says that they are certainly distinct; a conclusion in conformity with the trifling difference of habit, of which, however, he was not aware.

The number, tameness, and disgusting habits of the carrionfeeding hawks of South America make them pre-eminently striking to any one accustomed only to the birds of Northern Europe. In this list may be included four species of the Caracara or Polyborus, the Turkey buzzard, the Gallinazo, and the Condor. The Caracaras are, from their structure, placedamong the eagles: we shall soon see how ill they become so high a rank. In their habits they well supply the place of our carrion-crows, magpies, and ravens; a tribe of birds widely distributed over the rest of the world, but entirely absent in South America. To begin with the Polyborus Brasiliensis: this is a common bird, and has a wide geographical range; it is most numerous on the grassy savannahs of La Plata (where it goes by the name of Carrancha), and is far from unfrequent throughout the sterile plains of Patagonia. In the desert between the rivers Negro and Colorado, numbers constantly attend the line of road to devour the carcasses of the exhausted animals which chance to perish from fatigue and thirst. Although thus common in these dry and open countries, and likewise on the arid shores of the Pacific, it is nevertheless found inhabiting the damp impervious forests of West Patagonia and Tierra del Fuego. The Carranchas, 
together with the Chimango, constantly attend in numbers the estancias and slaughtering-houses. If an animal dies on the plain the Gallinazo commences the feast, and then the two species of Polyborus pick the bones clean. These birds, although thus commonly feeding together, are far from being friends. When the Carrancha is quietly seated on the branch of a tree or on the ground, the Chimango often continues for a long time flying backwards and forwards, up and down, in a semicircle, trying each time at the bottom of the curve to strike its larger relative. The Carrancha takes little notice, except by bobbing its head. Although the Carranchas frequently assemble in numbers, they are not gregarious; for in desert places they may be seen solitary, or more commonly by pairs.

The Carranchas are said to be very crafty, and to steal great numbers of eggs. 'They attempt, also, together with the Chimango, to pick off the scabs from the sore backs of horses and mules. The poor animal, on the one hand, with its ears down and its back arched; and, on the other, the hovering bird, eyeing at the distance of a yard, the disgusting morsel, form a picture, which has been described by Captain Head with his own peculiar spirit and accuracy. These false eagles most rarely kill any living bird or animal; and their vulture-like, necrophagous habits are very evident to any one, who has fallen asleep on the desolate plains of Patagonia, for when he wakes, he will see, on each surrounding hillock, one of these birds patiently watching him with an evil eye: it is a feature in the landscape of these countries, which will be recognised by every one who has wandered over them. If a party of men go out hunting with dogs and horses, they will be accompanied, during the day, by several of these attendants. After feeding, the uncovered craw protrudes; at such times, and indeed generally, the Carrancha is an inactive, tame, and cowardly bird. Its flight is heavy and slow, like that of an English rook. It seldom soars; but I have twice seen one at a great height gliding through the air with much ease. It runs (in contradistinction to hopping), but not quite so quickly as some of its congeners. At times the Carrancha is noisy, but is not generally so: its cry is loud, very harsh and peculiar, and may be likened to the sound of the Spanish guttural $g$, followed by a rough double $r r$; when utter- 
ing this cry it elevates its head higher and higher, till at last, with its beak wide open, the crown almost touches the lower part of the back. This fact, which has been doubted, is quite true ; I have seen them several times with their heads backwards in a completely inverted position. To these observations I may add, on the high authority of Azara, that the Carrancha feeds on worms, shells, slugs, grasshoppers, and frogs; that it destroys young lambs by tearing the umbilical cord; and that it pursues the Gallinazo, till that bird is compelled to vomit up the carrion it may have recently gorged. Lastly, Azara states that several Carranchas, five or six together, will unite in chace of large birds, even such as herons. All these facts show that it is a bird of very versatile habits and considerable ingenuity.

The Polyborus Chimango is considerably smaller than the last species. It is truly omnivorous, and will eat even bread; and I was assured that it materially injures the potato-crops in Chiloe, by stocking up the roots when first planted. Of all the carrion-feeders it is generally the last which leaves the skeleton of a dead animal; and may often be seen within the ribs of a cow or horse, like a bird in a cage. Another species is the Polyborus Novæ Zelandiæ, which is exceedingly common in the Falkland Islands. These birds in many respects resemble in their habits the Carranchas. 'They live on the flesh of dead animals and on marine productions; and on the Ramirez rocks their whole sustenance must depend on the sea. They are extraordinarily tame and fearless, and haunt the neighbourhood of houses for offal. If a hunting party kills an animal, a number soon collect and patiently await, standing on the ground on all sides. After eating, their uncovered craws are largely protruded, giving them a disgusting appearance. They readily attack wounded birds : a cormorant in this state having taken to the shore, was immediately seized on by several, and its death hastened by their blows. The Beagle was at the Falklands only during the summer, but the officers of the Adventure, who were there in the winter, mention many extraordinary instances of the boldness and rapacity of these birds. They actually pounced on a dog that was lying fast asleep close by one of the party; and the sportsmen had difficulty in preventing the wounded geese from being seized before their eyes. It is said that several 
together (in this respect resembling the Carranchas) wait at the mouth of a rabbit-hole, and together seize on the animal when it comes out. They were constantly flying on board the vessel when in the harbour; and it was necessary to keep a good look out to prevent the leather being torn from the rigging, and the meat or game from the stern. These birds are very mischievous and inquisitive; they will pick up almost any thing from the ground; a large black glazed hat was carried nearly a mile, as was a pair of the heavy balls used in catching cattle. Mr. Usborne experienced during the survey a more severe loss, in their stealing a small Kater's compass in a red morocco leather case, which was never recovered. These birds are, moreover, quarrelsome and very passionate; tearing up the grass with their bills from rage. They are not truly gregarious; they do not soar, and their flight is heavy and clumsy; on the ground they run extremely fast, very much like pheasants. They are noisy, uttering several harsh cries; one of which is like that of the English rook; hence the sealers always call them rooks. It is a curious circumstance that, when crying out, they throw their heads upwards and backwards, after the same manner as the Carrancha. They build in the rocky cliffs of the sea-coast, but only on the small adjoining islets, and not on the two main islands: this is a singular precaution in so tame and fearless a bird. The sealers say that the flesh of these birds, when cooked, is quite white, and very good eating; but bold must the man be who attempts such a meal.

We have now only to mention the turkey-buzzard (Vultur aura), and the Gallinazo. The former is found wherever the country is moderately damp, from Cape Horn to North America. Differently from the Polyborus Brasiliensis and Chimango, it has found its way to the Falkland Islands. The turkey-buzzard is a solitary bird, or at most goes in pairs. It may at once be recognised from a long distance, by its lofty, soaring, and most elegant flight. It is well known to be a true carrion-feeder. On the west coast of Patagonia, among the thickly-wooded islets and broken land, it lives exclusively on what the sea throws up, and on the carcasses of dead seals. Wherever these animals are congregated on the rocks, there the vultures may be seen. The Gallinazo (Cathartes atratus) has a different range from 
the last species, as it never occurs southward of lat. $41^{\circ}$. Azara states that there exists a tradition that these birds, at the time of the conquest, were not found near Monte Video, but that they subsequently followed the inhabitants from more northern districts. At the present day they are numerous in the valley of the Colorado, which is three hundred miles due south of Monte Video. It seems probable that this additional migration has happened since the time of Azara. The Gallinazo generally prefers a humid climate, or rather the neighbourhood of fresh water; hence it is extremely abundant in Brazil and La Plata, while it is never found on the desert and arid plains of Northern Patagonia, excepting near some stream. These birds frequent the whole Pampas to the foot of the Cordillera, but I never saw or heard of one in Chile : in Peru they are preserved as scavengers. These vultures certainly may be called gregarious, for they seem to have pleasure in society, and are not solely brought together by the attraction of a common prey. On a fine day a flock may often be observed at a great height, each bird wheeling round and round without closing its wings, in the most graceful evolutions. This is clearly performed for the mere pleasure of the exercise, or perhaps is connected with their matrimonial alliances.

I have now mentioned all the carrion-feeders, excepting the condor, an account of which will be more appropriately introduced when we visit a country more congenial to its habits than the plains of $\mathrm{La}$ Plata.

In a broad band of sand-hillocks which separate the Laguna del Potrero from the shores of the Plata, at the distance of a few miles from Maldonado, I found a group of those vitrified, siliceous tubes, which are formed by lightning entering loose sand. These tubes resemble in every particular those from Drigg in Cumberland, described in the Geological Transactions.* 'The sand-hillocks of Maldonado, not being protected by vegetation, are constantly changing their position. From this cause the

* Geolog. Transact., vol. ii. p. 528. In the Philosoph. Transact. (1790, p. 294) Dr. Priestley has described some imperfect siliceous tubes and a melted pebble of quartz, found in digging into the ground, under a tree, where a man had been killed by lightning. 
tubes projected above the surface; and numerous fragments lying near, showed that they had formerly been buried to a greater depth. Four sets entered the sand perpendicularly : by working with my hands I traced one of them two feet deep; and some fragments which evidently had belonged to the same tube, when added to the other part, measured five feet three inches. The diameter of the whole tube was nearly equal, and therefore we must suppose that originally it extended to a much greater depth. These dimensions are however small, compared to those of the tubes from Drigg, one of which was traced to a depth of not less than thirty feet.

The internal surface is completely vitrified, glossy, and smooth. A small fragment examined under the microscope appeared, from the number of minute entangled air or perhaps steam bubbles, like an assay fused before the blowpipe. The sand is entirely, or in greater part, siliceous; but some points are of a black colour, and from their glossy surface possess a metallic lustre. The thickness of the wall of the tube varies from a thirtieth to a twentieth of an inch, and occasionally even equals a tenth. On the outside the grains of sand are rounded, and have a slightly glazed appearance: I could not distinguish any signs of crystallization. In a similar manner to that described in the Geological Transactions, the tubes are generally compressed, and have deep longitudinal furrows, so as closely to resemble a shrivelled vegetable stalk, or the bark of the elm or cork tree. Their circumference is about two inches, but in some fragments, which are cylindrical and without any furrows, it is as much as four inches. The compression from the surrounding loose sand, acting while the tube was still softened from the effects of the intense heat, has evidently caused the creases or furrows. Judging from the uncompressed fragments, the measure or bore of the lightning (if such a term may be used), must have been about one inch and a quarter. At Paris, M. Hachette and M. Beudant* succeeded in making tubes, in most respects similar to these fulgurites, by passing very strong shocks of galvanism through finely-powdered glass: when salt was added, so as to increase its fusibility, the tubes were larger in every

* Annales de Chimie et de Physique, tom. xxxvii., p. 319. 
dimension. They failed both with powdered felspar and quartz. One tube, formed with pounded glass, was very nearly an inch long, namely, .982, and had an internal diameter of $\cdot 019$ of an inch. When we hear that the strongest battery in Paris was used, and that its power on a substance of such easy fusibility as glass was to form tubes so diminutive, we must feel greatly astonished at the force of a shock of lightning, which, striking the sand in several places, has formed cylinders, in one instance of at least thirty feet long, and having an internal bore, where not compressed, of full an inch and a half; and this in a material so extraordinarily refractory as quartz!

The tubes, as I have already remarked, enter the sand nearly in a vertical direction. One, however, which was less regular than the others, deviated from a right line, at the most considerable bend, to the amount of thirty-three degrees. From this same tube, two small branches, about a foot apart, were sent off; one pointed downwards, and the other upwards. This latter case is remarkable, as the electric fluid must have turned back at the acute angle of $26^{\circ}$, to the line of its main course. Besides the four tubes which I found vertical, and traced beneath the surface, there were several other groups of fragments, the original sites of which without doubt were near. All occurred in a level area of shifting sand, sixty yards by twenty, situated among some high sand-hillocks, and at the distance of about half a mile from a chain of hills four or five hundred feet in height. The most remarkable circumstance, as it appears to me, in this case as well as in that of Drigg, and in one described by M. Ribbentrop in Germany, is the number of tubes found within such limited spaces. At Drigg, within an area of fifteen yards, three were observed, and the same number occurred in Germany. In the case which I have described, certainly more than four existed within the space of the sixty by twenty yards. As it does not appear probable that the tubes are produced by successive distinct shocks, we must believe that the lightning, shortly before entering the ground, divides itself into separate branches.

The neighbourhood of the Rio Plata seems peculiarly subject to electric phenomena. In the year 1793,* one of the most

* Azara's Voyage, vol. i. p. 36. 
destructive thunderstorms perhaps on record happened at Buenos Ayres : thirty-seven places within the city were struck by lightning, and nineteen people killed. From facts stated in several books of travels, I am inclined to suspect that thunderstorms are very common near the mouths of great rivers. Is it not possible that the mixture of large bodies of fresh and salt water may disturb the electrical equilibrium? Even during our occasional visits to this part of South America, we heard of a ship, two churches, and a house, having been struck. Both the church and the house I saw shortly afterwards : the house belonged to Mr. Hood, the consul-general at Monte Video. Some of the effects were curious : the paper, for nearly a foot on each side of the line where the bell-wires had run, was blackened. The metal had been fused, and although the room was about fifteen feet high, the globules, dropping on the chairs and furniture, had drilled in them a chain of minute holes. A part of the wall was shattered as if by gunpowder, and the fragments had been blown off with force sufficient to dent the wall on the opposite side of the room. The frame of a looking-glass was blackened, and the gilding must have been volatilized, for a with bright metallic particles, which adhered as firmly as if they
had been enamelled. 


\section{CHAPTER IV.}

Rio Negro-Estancias attacked by the Indians-Salt Lakes-FlamingoesR. Negro to R. Colorado-Sacred Tree-Patagonian Hare-Indian Families - General Rosas-Proceed to Bahia Blanca-Sand Dunes-Negro Lieutenant-Bahia Blanca-Saline Incrustations-Punta Alta-Zorillo.

RIO NEGRO TO BAHIA BLANCA.

July 24th, 1833.-The Beagle sailed from Maldonado, and on August the 3rd she arrived off the mouth of the Rio Negro. This is the principal river on the whole line of coast between the Strait of Magellan and the Plata. It enters the sea about three hundred miles south of the estuary of the Plata. About fifty years ago, under the old Spanish government, a small colony was established here; and it is still the most southern position (lat. $41^{\circ}$ ) on this eastern coast of America, inhabited by civilized man.

The country near the mouth of the river is wretched in the extreme: on the south side a long line of perpendicular cliffs commences, which exposes a section of the geological nature of the country. The strata are of sandstone, and one layer was remarkable from being composed of a firmly-cemented conglomerate of pumice pebbles, which must have travelled more than four hundred miles, from the Andes. The surface is everywhere covered up by a thick bed of gravel, which extends far and wide over the open plain. Water is extremely scarce, and, where found, is almost invariably brackish. The vegetation is scanty; and although there are bushes of many kinds, all are armed with formidable thorns, which seem to warn the stranger not to enter on these inhospitable regions.

The settlement is situated eighteen miles up the river. The road follows the foot of the sloping cliff, which forms the northern boundary of the great valley, in which the Rio Negro flows. On the way we passed the ruins of some fine "estancias," which a few years since had been destroyed by the Indians. They with- 
stood several attacks. A man present at one gave me a very lively description of what took place. The inhabitants had sufficient notice to drive all the cattle and horses into the "corral"* which surrounded the house, and likewise to mount some small cannon. The Indians were Araucanians from the south of Chile ; several hundreds in number, and highly disciplined. They first appeared in two bodies on a neighbouring hill; having there dismounted, and taken off their fur mantles, they advanced naked to the charge. The only weapon of an Indian is a very long bamboo or chuzo, ornamented with ostrich feathers, and pointed by a sharp spear-head. My informer seemed to remember with the greatest horror the quivering of these chuzos as they approached near. When close, the cacique Pincheira hailed the besieged to give up their arms, or he would cut all their throats. As this would probably have been the result of their entrance under any circumstances, the answer was given by a volley of musketry. The Indians, with great steadiness, came to the very fence of the corral: but to their surprise they found the posts fastened together by iron nails instead of leather thongs, and, of course, in vain attempted to cut them with their knives. This saved the lives of the Christians : many of the wounded Indians were carried away by their companions; and at last one of the under caciques being wounded, the bugle sounded a retreat. They retired to their horses, and seemed to hold a council of war. This was an awful pause for the Spaniards, as all their ammunition, with the exception of a few cartridges, was expended. In an instant the Indians mounted their horses, and galloped out of sight. Another attack was still more quickly repulsed. A cool Frenchman managed the gun; he stopped till the Indians approached close, and then raked their line with grape-shot: he thus laid thirty-nine of them on the ground; and, of course, such a blow immediately routed the whole party.

The town is indifferently called El Carmen or Patagones. It is built on the face of a cliff which fronts the river, and many of the houses are excavated even in the sandstone. The river is about two or three hundred yards wide, and is deep and rapid. The many islands, with their willow-trees, and the flat headlands, * The corral is an enclosure made of tall and strong stakes. Every
estancia, or farming estate, has one attached to it. 
seen one behind the other on the northern boundary of the broad green valley, forms, by the aid of a bright sun, a view almost picturesque. The number of inhabitants does not exceed a few hundreds. These Spanish colonies do not, like our British ones, carry within themselves the elements of growth. Many Indians of pure blood reside here: the tribe of the Cacique Lucanee constantly have their Toldos* on the outskirts of the town. The local government partly supplies them with provisions, by giving them all the old worn-out horses, and they earn a little by' making horse-rugs and other articles of riding-gear. These Indians are considered civilized; but what their character may have gained by a lesser degree of ferocity, is almost counterbalanced by their entire immorality. Some of the younger men are, however, improving; they are willing to labour, and a short time since a party went on a sealing-voyage, and behaved very well. They were now enjoying the fruits of their labour, by being dressed in very gay, clean clothes, and by being very idle. The taste they showed in their dress was admirable; if you could have turned one of these young Indians into a statue of bronze, his drapery would have been perfectly graceful.

One day I rode to a large salt-lake, or Salina, which is distant fifteen miles from the town. During the winter it consists of a shallow lake of brine, which in summer is converted into a field of snow-white salt. The layer near the margin is from four to five inches thick, but towards the centre its thickness increases. This lake was two and a half miles long, and one broad. Others occur in the neighbourhood many times larger, and with a floor of salt, two and three feet in thickness, even when under water during the winter. One of these brilliantly-white and level expanses, in the midst of the brown and desolate plain, offers an extraordinary spectacle. A large quantity of salt is annually drawn from the salina; and great piles, some hundred tons in weight, were lying ready for exportation. The season for working the salinas forms the harvest of Patagones; for on it, the prosperity of the place depends. Nearly the whole population encamps on the bank of the river, and the people are employed in drawing out the salt in bullock-waggons. This salt is crystal-

* The hovels of the Indians are thus called. 
lized in great cubes, and is remarkably pure : Mr. Trenham Reeks has kindly analyzed some for me, and he finds in it only 0.26 of gypsum and 0.22 of earthy matter. It is a singular fact, that it does not serve so well for preserving meat as sea-salt from the Cape de Verd islands; and a merchant at Buenos Ayres told me that he considered it as fifty per cent. less valuable. Hence the Cape de Verd salt is constantly imported, and is mixed with that from these salinas. The purity of the Patagonian salt, or absence from it of those other saline bodies found in all sea-water, is the only assignable cause for this inferiority : a conclusion which no one, I think, would have suspected, but which is supported by the fact lately ascertained, ${ }^{*}$ that those salts answer best for preserving cheese which contain most of the deliquescent chlorides.

The border of the lake is formed of mud: and in this numerous large crystals of gypsum, some of which are three inches long, lie embedded; whilst on the surface others of sulphate of soda lie scattered about. The Gauchos, call the former the "Padre del sal," and the latter the "Madre;" they state that these progenitive salts always occur on the borders of the salinas, when the water begins to evaporate. The mud is black, and has a fetid odour. I could not at first imagine the cause of this, but I afterwards perceived that the froth which the wind drifted on shore was coloured green, as if by confervæ : I attempted to carry home some of this green matter, but from an accident failed. Parts of the lake seen from a short distance appeared of a reddish colour, and this perhaps was owing to some infusorial animalcula. The mud in many places was thrown up by numbers of some kind of worm, or annelidous animal. How surprising it is that any creatures should be able to exist in brine, and that they should be crawling among crystals of sulphate of soda and lime! And what becomes of these worms when, during the long summer, the surface is hardened into a solid layer of salt? Flamingoes in considerable numbers inhabit this lake, and breed here; throughout Patagonia, in Northern Chile, and at the Galapagos Islands, I met with these birds wherever there were lakes of brine. I saw them here wading about in search of food-probably for the worms which burrow in the mud; and these latter probably feed

* Report of the Agricult. Chem. Assoc. in the Agricult. Gazette, 1845, r. 93. 
on infusoria or confervæ. Thus we have a little living world within itself, adapted to these inland lakes of brine. A minute crustaceous animal (Cancer salinus) is said * to live in countless numbers in the brine-pans at Lymington; but only in those in which the fluid has attained, from evaporation, considerable strength-namely, about a quarter of a pound of salt to a pint of water. Well may we affirm, that every part of the world is habitable! Whether lakes of brine, or those subterranean ones hidden beneath volcanic mountains-warm mineral springs-the wide expanse and depths of the ocean-the upper regions of the atmosphere, and even the surface of perpetual snow-all support oryanic beings.

To the northward of the Rio Negro, between it and the inhabited country near Buenos Ayres, the Spaniards have only one small settlement, recently established at Bahia Blanca. The distance in a straight line to Buenos Ayres is very nearly five hundred British miles. The wandering tribes of horse Indians, which have always occupied the greater part of this country, having of late much harassed the outlying estancias, the government at Buenos Ayres equipped some time since an army under the command of General Rosas for the purpose of exterminating them. The troops were now encamped on the banks of the Colorado; a river lying about eighty miles northward of the Rio Negro. When General Rosas left Buenos Ayres he struck in a direct line across the unexplored plains: and as the country was thus pretty well cleared of Indians, he left behind him, at wide intervals, a small party of soldiers with a troop of horses ( a posta), so as to be enabled to keep up a communication with

- Linnæan Trans., vol. xi. p. 205. It is remarkable how all the circumstances connected with the salt-lakes in Siberia and Patagonia are similar. Siberia, like Patagonia, appears to have been recently elevated above the waters of the sea. In both countries the salt-lakes occupy shallow depressions in the plains; in both the mud on the borders is black and fetid; beneath the crust of common salt, sulphate of soda or of magnesia occurs, imperfectly crystallized; and in both, the muddy sand is mixed with lentils of gypsum. The Siberian salt-lakes are inhabited by small crustaceous animals; and flamingoes (Edin. New Philos. Jour., Jan. 1830) likewise frequent them. As these circumstances, apparently so trifling, occur in two distant continents, we may feel sure that, they are the necessary results of common causes.-See Pallas's Travels, 1793 to 1794, pp. 129-134. 
the capital. As the Beagle intended to call at Bahia Blanca, I determined to proceed there by land; and ultimately I extended my plan to travel the whole way by the postas to Buenos Ayres.

August 11th.-Mr. Harris, an Englishman residing at Patagones, a guide, and five Gauchos, who were proceeding to the army on business, were my companions on the journey. The Colorado, as I have already said, is nearly eighty miles distant: and as we travelled slowly, we were two days and a half on the road. The whole line of country deserves scarcely a better name than that of a desert. Water is found only in two small wells; it is called fresh; but even at this time of the year, during the rainy season, it was quite brackish. In the summer this must be a distressing passage; for now it was sufficiently desolate. The valley of the Rio Negro, broad as it is, has merely been excavated out of the sandstone plain; for immediately above the bank on which the town stands, a level country commences, which is interrupted only by a few trifling valleys and depressions. Everywhere the landscape wears the same sterile aspect; a dry gravelly soil supports tufts of brown withered grass, and low scattered bushes, armed with thorns.

Shortly after passing the first spring we came in sight of a famous tree, which the Indians reverence as the altar of Walleechu. It is situated on a high part of the plain, and hence is a landmark visible at a great distance. As soon as a tribe of Indians come in sight of it, they offer their adorations by loud shouts. The tree itself is low, much branched, and thorny: just above the root it has a diameter of about three feet. It stands by itself without any neighbour, and was indeed the first tree we saw ; afterwards we met with a few others of the same kind, but they were far from common. Being winter the tree had no leaves, but in their place numberless threads, by which the various offerings, such as cigars, bread, meat, pieces of cloth, \&c. had been suspended. Poor Indians, not having anything better, only pull a thread out of their ponchos, and fasten it to the tree. Richer Indians are accustomed to pour spirits and maté into a certain hole, and likewise to smoke upwards, thinking thus to afford all possible gratification to Walleechu. To complete the scene, the tree was surrounded by the bleached 
bones of horses which had been slaughtered as sacrifices. All Indians of every age and sex make their offerings; they then think that their horses will not tire, and that they themselves shall be prosperous. The Gaucho who told me this, said that in the time of peace he had witnessed this scene, and that he and others used to wait till the Indians had passed by, for the sake of stealing from Walleechu the offerings.

The Gauchos think that the Indians consider the tree as the god itself; but it seems far more probable, that they regard it as the altar. The only cause which I can imagine for this choice, is its being a landmark in a dangerous passage. The Sierra de la Ventana is visible at an immense distance; and a Gaucho told me that he was once riding with an Indian a few miles to the north of the Rio Colorado, when the Indian commenced making the same loud noise, which is usual at the first sight of the distant tree; putting his hand to his head, and then pointing in the direction of the Sierra. Upon being asked the reason of this, the Indian said in broken Spanish, "First see the Sierra." About two leagues beyond this curious tree we halted for the night: at this instant an unfortunate cow was spied by the lynxeyed Gauchos, who set off in full chace, and in a few minutes dragged her in with their lazos, and slaughtered her. We here had the four necessaries of life "en el campo,"-pasture for the horses, water (only a muddy puddle), meat and firewood. The Gauchos were in high spirits at finding all these luxuries; and we soon set to work at the poor cow. This was the first night which I passed under the open sky, with the gear of the recado for my bed. There is high enjoyment in the independence of the Gaucho life-to be able at any moment to pull up your horse, and say, "Here we will pass the night." The death-like stillness of the plain, the dogs keeping watch, the gipsy-group of Gauchos making their beds round the fire, have left in my mind a strongly-marked picture of this first night, which will never be forgotten.

The next day the country continued similar to that above described. It is inhabited by few birds or animals of any kind. Occasionally a deer, or a Guanaco (wild Llama) may be seen; but the Agouti (Cavia Patagonica) is the commonest quadruped. This animal here represents our hares. It differs, however, from 
that genus in many essential respects; for instance, it has only three toes behind. It is also nearly twice the size, weighing from twenty to twenty-five pounds. The Agouti is a true friend of the desert; it is a common feature in the landscape to see two or three hopping quickly one after the other in a straight line across these wild plains. They are found as far north as the Sierra Tapalguen (lat. $37^{\circ} 30^{\prime}$ ), where the plain rather suddenly becomes greener and more humid; and their southern limit is between Port Desire and St. Julian, where there is no change in the nature of the country. It is a singular fact, that although the Agouti is not now found as far south as Port St. Julian, yet that Captain Wood, in his voyage in 1670, talks of them as being numerous there. What cause can have altered, in a wide, uninhabited, and rarely-visited country, the range of an animal like this? It appears also from the number shot by Captain Wood in one day at Port Desire, that they must have been considerably more abundant there formerly than at present. Where the Bizcacha lives and makes its burrows, the Agouti uses them; but where, as at Bahia Blanca, the Bizcacha is not found, the Agouti burrows for itself. The same thing occurs with the little owl of the Pampas (Athene cunicularia), which has so often been described as standing like a sentinel at the mouth of the burrows; for in Banda Oriental, owing to the absence of the Bizcacha, it is obliged to hollow out its own habitation.

The next morning, as we approached the Rio Colorado, the appearance of the country changed; we soon came on a plain covered with turf, which, from its flowers, tall clover, and little owls, resembled the Pampas. We passed also a muddy swamp of considerable extent, which in summer dries, and becomes incrusted with various salts; and hence is called a salitral. It was covered by low succulent plants, of the same kind with those growing on the sea-shore. The Colorado, at the pass where we crossed it, is only about sixty yards wide; generally it must be nearly double that width. Its course is very tortuous, being marked by willow-trees and beds of reeds : in a direct line the distance to the mouth of the river is said to be nine leagues, but by water twenty-five. We were delayed crossing in the canoe by some immense troops of mares, which were swimming the 
river in order to follow a division of troops into the interior. A more ludicrous spectacle I never beheld than the hundreds and hundreds of heads, all directed one way, with pointed ears and distended snorting nostrils, appearing just above the water like a great shoal of some amphibious animal. Mare's flesh is the only food which the soldiers have when on an expedition. This gives them a great facility of movement; for the distance to which horses can be driven over these plains is quite surprising: I have been assured that an unloaded horse can travel a hundred miles a day for many days successively.

The encampment of General Rosas was close to the river. It consisted of a square formed by waggons, artillery, straw huts, \&c. The soldiers were nearly all cavalry; and I should think such a villanous, banditti-like army was never before collected together. The greater number of men were of a mixed breed, between Negro, Indian, and Spaniard. I know not the reason, but men of such origin seldom have a good expression of countenance. I called on the Secretary to show my passport. He began to cross-question me in the most dignified and mysterious manner. By good luck I had a letter of recommendation from the government of Buenos Ayres * to the commandant of Patagones. This was taken to General Rosas, who sent me a very obliging message ; and the Secretary returned all smiles and graciousness. We took up our residence in the rancho, or hovel, of a curious old Spaniard, who had served with Napoleon in the expedition against Russia.

We stayed two days at the Colorado; I had little to do, for the surrounding country was a swamp, which in summer (December), when the snow melts on the Cordillera, is overflowed by the river. My chief amusement was watching the Indian families as they came to buy little articles at the rancho where we stayed. It was supposed that General Rosas had about six hundred Indian allies. The men were a tall, fine race, yet it was afterwards easy to see in the Fuegian savage the same countenance rendered hideous by cold, want of food, and less civilization. Some authors, in defining the primary races of mankind, have sepa-

* I am bound to express, in the strongest terms, my obligation to the Government of Buenos Ayres for the obliging manner in which passports to all parts of the country were given me, as naturalist of the Beagle. 
rated these Indians into two classes; but this is certainly incorrect. Among the young women or chinas, some deserve to be called even beautiful. Their hair was coarse, but bright and black; and they wore it in two plaits hanging down to the waist. They had a high colour, and eyes that glistened with brilliancy; their legs, feet, and arms were small and elegantly formed; their ankles, and sometimes their waists, were ornamented by broad bracelets of blue beads. Nothing could be more interesting than some of the family groups. A mother with one or two daughters would often come to our rancho, mounted on the same horse. They ride like men, but with their knees tucked up much higher. This habit, perhaps, arises from their being accustomed, when travelling, to ride the loaded horses. The duty of the women is to load and unload the horses; to make the tents for the night; in short to be, like the wives of all savages, useful slaves. The men fight, hunt, take care of the horses, and make the riding gear. One of their chief indoor occupations is to knock two stones together till they become round, in order to make the bolas. With this important weapon the Indian catches his game, and also his horse, which roams free over the plain. In fighting, his first attempt is to throw down the horse of his adversary with the bolas, and when entangled by the fall to kill him with the chuzo. If the balls only catch the neck or body of an animal, they are often carried away and lost. As the making the stones round is the labour of two days, the manufacture of the balls is a very common employment. Several of the men and women had their faces painted red, but I never saw the horizontal bands which are so common among the Fuegians. Their chief pride consists in having everything made of silver; I have seen a cacique with his spurs, stirrups, handle of his knife, and bridle made of this metal: the head-stall and reins being of wire, were not thicker than whipcord; and to see a fiery steed wheeling about under the command of so light a chain, gave to the horsemanship a remarkable character of elegance.

General Rosas intimated a wish to see me; a circumstance which $I$ was afterwards very glad of. He is a man of an extraordinary character, and has a most predominant influence in the country, which it seems probable he will use to its prosperity 
and advancement.* $\mathrm{He}$ is said to be the owner of seventy-four square leagues of land, and to have about three hundred thousand head of cattle. His estates are admirably managed, and are far more productive of corn than those of others. He first gained his celebrity by his laws for his own estancias, and by disciplining several hundred men, so as to resist with success the attacks of the Indians. There are many stories current about the rigid manner in which his laws were enforced. One of these was, that no man, on penalty of being put into the stocks, should carry his knife on a Sunday: this being the principal day for gambling and drinking, many quarrels arose, which from the general manner of fighting with the knife often proved fatal. One Sunday the Governor came in great form to pay the estancia a visit, and General Rosas, in his hurry, walked out to receive him with his knife, as usual, stuck in his belt. The steward touched his arm, and reminded him of the law; upon which turning to the Governor, he said he was extremely sorry, but that he must go into the stocks, and that till let out, he possessed no power even in his own house. After a little time the steward was persuaded to open the stocks, and to let him out, but no sooner was this done, than he turned to the steward and said, "You now have broken the laws, so you must take my place in the stacks." Such actions as these delighted the Gauchos, who all passess high notions of their own equality and dignity.

General Rosas is also a perfect horseman-an accomplishment of no small consequence in a country where an assembled army elected its general by the following trial: A troop of unbroken horses being driven into a corral, were let out through a gateway, above which was a cross-bar: it was agreed whoever should drop from the bar on one of these wild animals, as it rushed out, and should be able, without saddle or bridle, not only to ride it, but also to bring it back to the door of the corral, should be their general. The person who succeeded was accordingly elected; and doubtless made a fit general for such an army. This extraordinary feat has also been performed by Rosas.

By these means, and by conforming to the dress and babits of

* This prophecy has turned out entirely and miserably wrong. 1845. 
the Gauchos, he has obtained an unbounded popularity in the country, and in consequence a despotic power. I was assured by an English merchant, that a man who had murdered another, when arrested and questioned concerning his motive, answered, "He spoke disrespectfully of General Rosas, so I killed him." At the end of a week the murderer was at liberty. This doubtless was the act of the general's party, and not of the general himself.

In conversation he is enthusiastic, sensible, and very grave. His gravity is carried to a high pitch: I heard one of his mad buffoons (for he keeps two, like the barons of old) relate the following anecdote: "I wanted very much to hear a certain piece of music, so I went to the general two or three times to ask him; he said to me, 'Go about your business, for I am engaged.' I went a second time ; he said, 'If you come again I will punish you.' A third time I asked, and he laughed. I rushed out of the tent, but it was too late; he ordered two soldiers to catch and stake me. I begged by all the Saints in heaven he would let me off; but it would not do;-when the general laughs he spares neither mad man nor sound." The poor flighty gentleman looked quite dolorous, at the very recollection of the staking. This is a very severe punishment; four posts are driven into the ground, and the man is extended by his arms and legs horizontally, and there left to stretch for several hours. The idea is evidently taken from the usual method of drying hides. My interview passed away without a smile, and I obtained a passport and order for the government post-horses, and this he gave me in the most obliging and ready manner.

In the morning we started for Bahia Blanca, which we reached in two days. Leaving the regular encampment, we passed by the toldos of the Indians. These are round like ovens, and covered with hides; by the mouth of each, a tapering chuzo was stuck in the ground. The toldos were divided into separate groups, which belonged to the different caciques' tribes, and the groups were again divided into smaller ones, according to the relationship of the owners. For several miles we travelled along the valley of the Colorado. The alluvial plains on the side appeared fertile, and it is supposed that they are well adapted to the growth of corn. Turning northward from the 
river, we soon entered on a country, differing from the plains south of the river. The land still continued dry and sterile; but it supported many different kinds of plants, and the grass, though brown and withered, was more abundant, as the thorny bushes were less so. These latter in a short space entirely disappeared, and the plains were left without a thicket to cover their nakedness. This change in the vegetation marks the commencement of the grand calcareo-argillaceous deposit, which forms the wide extent of the Pampas, and covers the granitic rocks of Banda Oriental. From the Strait of Magellan to the Colorado, a distance of about eight hundred miles, the face of the country is everywhere composed of shingle: the pebbles are chiefly of porphyry, and probably owe their origin to the rocks of the Cordillera. North of the Colorado this bed thins out, and the pebbles become exceedingly small, and here the characteristic vegetation of Patagonia ceases.

Having ridden about twenty-five miles, we came to a broad belt of sand-dunes, which stretches, as far as the eye can reach, to the east and west. The sand-hillocks resting on the clay, allow small pools of water to collect, and thus afford in this dry country an invaluable supply of fresh water. The great advantage arising from depressions and elevations of the soil, is not often brought home to the mind. The two miserable springs in the long passage between the Rio Negro and Colorado were caused by trifling inequalities in the plain; without them not a drop of water would have been found. The belt of sand-dunes is about eight miles wide; at some former period, it probably formed the margin of a grand estuary, where the Colorado now flows. In this district, where absolute proofs of the recent elevation of the land occur, such speculations can hardly be neglected by any one, although merely considering the physical geography of the country. Having crossed the sandy tract, we arrived in the evening at one of the post-houses; and, as the fresh horses were grazing at a distance, we determined to pass the night there.

The house was situated at the base of a ridge, between one and two hundred feet high-a most remarkable feature in this country. This posta was commanded by a negro lieutenant, born in Africa: to his credit be it said, there was not a rancho 
between the Colorado and Buenos Ayros in nearly such neat order as his. He had a little room for strangers, and a small corral for the horses, all made of sticks and reeds; he had also dug a ditch round his house, as a defence in case of being attacked. This would, however, have been of little avail, if the Indians had come; but his chief comfort seemed to rest in the thought of selling his life dearly. A short time before, a body of Indians had travelled past in the night; if they had been aware of the posta, our black friend and his four soldiers would assuredly have been slaughtered. I did not any where meet a more civil and obliging man than this negro; it was therefore the more painful to see that he would not sit down and eat with us.

In the morning we sent for the horses very early, and started for another exhilarating gallop. We passed the Cabeza del Buey, an old name given to the head of a large marsh, which extends from Bahia Blanca. Here we changed horses, and passed through some leagues of swamps and saline marshes. Changing horses for the last time, we again began wading through the mud. My animal fell, and I was well soused in black mire-a very disagreeable accident, when one does not possess a change of clothes. Some miles from the fort we met a man, who told us that a great gun had been fired, which is a signal that Indians are near. We immediately left the road, and followed the edge of a marsh, which when chased offers the best mode of escape. We were glad to arrive within the walls, when we found all the alarm was about nothing, for the Indians turned out to be friendly ones, who wished to join General
Rosas.

Bahia Blanca scarcely deserves the name of a village. A few houses and the barracks for the troops are enclosed by a deep ditch and fortified wall. The settlement is only of recent standing (since 1828); and its growth has been one of trouble. The government of Buenos Ayres unjustly occupied it by force, instead of following the wise example of the Spanish Viceroys, who purchased the land near the older settlement of the Rio Negro, from the Indians. Hence the need of the fortifications; hence the few houses and little cultivated land without the limits of the walls: even the cattle are not safe from the attacks 
of the Indians beyond the boundaries of the plain, on which the fortress stands.

The part of the harbour where the Beagle intended to anchor being distant twenty-five miles, I obtained from the Commandant a guide and horses, to take me to see whether she had arrived. Leaving the plain of green turf, which extended along the course of a little brook, we soon entered on a wide level waste consisting either of sand, saline marshes, or bare mud. Some parts were clothed by low thickets, and others with those succulent plants, which luxuriate only where salt abounds. Bad as the country was, ostriches, deers, agoutis, and armadilloes, were abundant. My guide told me, that two months before he had a most narrow escape of his life : he was out hunting with two other men, at no great distance from this part of the country, when they were suddenly met by a party of Indians, who giving chace, soon overtook and killed his two friends. His own horse's legs were also caught by the bolas; but he jumped off, and with his knife cut them free: while doing this he was obliged to dodge round his horse, and received two severe wounds from their chuzos. Springing on the saddle, he managed, by a most wonderful exertion, just to keep ahead of the long spears of his pursuers, who followed him to within sight of the fort. From that time there was an order that no one should stray far from the settlement. I did not know of this when I started, and was surprised to observe how earnestly my guide watched a deer, which appeared to have been frightened from a distant quarter.

We found the Beagle had not arrived, and consequently set out on our return, but the horses soon tiring, we were obliged to bivouac on the plain. In the morning we had caught an armadillo, which, although a most excellent dish when roasted in its shell, did not make a very substantial breakfast and dinner for two hungry men. The ground at the place where we stopped for the night, was incrusted with a layer of sulphate of soda, and hence, of course, was without water. Yet many of the smaller rodents managed to exist even here, and the tucutuco was making its odd little grunt beneath my head, during half the night. Our horses were very poor ones, and in the morning they were soon exhausted from not having had any thing to drink, so that we were obliged to walk. About noon the dogs 
killed a kid, which we roasted. I ate some of it, but it made me intolerably thirsty. This was the more distressing as the road, from some recent rain, was full of little puddles of clear water, yet not a drop was drinkable. I had scarcely been twenty hours without water, and only part of the time under a hot sun, yet the thirst rendered me very weak. How people survive two or three days under such circumstances, I cannot imagine: at the same time, I must confess that my guide did not suffer at all, and was astonished that one day's deprivation should be so troublesome to me.

I have several times alluded to the surface of the ground being incrusted with salt. This phenomenon is quite different from that of the salinas, and more extraordinary. In many parts of South America, wherever the climate is moderately dry, these incrustations occur; but I have nowhere seen them so ahundant as near Bahia Blanca. The salt here, and in other parts of Patagonia, consists chiefly of sulphate of soda with some common salt. As long as the ground remains moist in these salitrales (as the Spaniards improperly call them, mistaking this substance for saltpetre), nothing is to be seen but an extensive plain composed of a black, muddy soil, supporting scattered tufts of succulent plants. On returning through one of these tracts, after a week's hot weather, one is surprised to see square miles of the plain white, as if from a slight fall of snow, here and there heaped up by the wind into little drifts. This latter appearance is chiefly caused by the salts being drawn up, during the slow evaporation of the moisture, round blades of dead grass, stumps of wood, and pieces of broken earth, instead of being crystallized at the bottoms of the puddles of water. The salitrales occur either on level tracts elevated only a few feet above the level of the sea, or on alluvial land bordering rivers. M. Parchappe* found that the saline incrustation on the plain, at the distance of some miles from the sea, consisted chiefly of sulphate of soda, with only seven per cent. of common salt; whilst nearer to the coast, the common salt increased to 37 parts in a hundred. This circumstance would tempt one to believe that the sulphate of soda is generated in the soil, from the muriate, left on the

* Voyage dans l'Amérique Mérid. par M. A. d'Orbigny. Part. Hist.
m. i. p. 664 . 
surface during the slow and recent elevation of this dry country. The whole phenomenon is well worthy the attention of naturalists. Have the succulent, salt-loving plants, which are well known to contain much soda, the power of decomposing the muriate? Does the black fetid mud, abounding with organic matter, yield the sulphur and ultimately the sulphuric acid?

Two days afterwards I again rode to the harbour: when not far from our destination, my companion, the same man as before, spied three people hunting on horseback. He immediately dismounted, and watching them intently, said, "They don't ride like Christians, and nobody can leave the fort." The three hunters joined company, and likewise dismounted from their horses. At last one mounted again and rode over the hill out of sight. My companion said, "We must now get on our horses: load your pistol;" and he looked to his own sword. I asked, "Are they Indians?"_-"Quien sabe? (who knows?) if there are no more than three, it does not signify." It then struck me, that the one man had gone over the hill to fetch the rest of his tribe. I suggested this; but all the answer I could extort was, "Quien sabe?" His head and eye never for a minute ceased scanning slowly the distant horizon. I thought his uncommon coolness too good a joke, and asked him why he did not return home. I was startled when he answered, "We are returning, but in a line so as to pass near a swamp, into which we can gallop the horses as far as they can go, and then trust to our own legs ; so that there is no danger." I did not feel quite so confident of this, and wanted to increase our pace. He said, " No, not until they do." When any little inequality concealed us, we galloped; but when in sight, continued walking. At last we reached a valley, and turning to the left, galloped quickly to the foot of a hill; he gave me his horse to hold, made the dogs lie down, and then crawled on his hands and knees to reconnoitre. He remained in this position for some time, and at last, bursting out in laughter, exclaimed, "Mugeres!" (women!) He knew them to be the wife and sister-in-law of the major's son, hunting for ostrich's eggs. I have described this man's conduct, because he acted under the full impression that they were Indians. As soon, however, as the absurd mistake was found out, he gave me 
a hundred reasons why they could not have been Indians; but all these were forgotten at the time. We then rode on in peace and quietness to a low point ealled Punta Alta, whence we could see nearly the whole of the great harbour of Bahia Blanca.

The wide expanse of water is choked up by numerous great mud-banks, which the inhabitants call Cangrejales, or crabberies, from the number of small crabs. The mud is so soft that it is impossible to walk over them, even for the shortest distance. Many of the banks hagve their surfaces covered with long rushes, the tops of which alone are visible at high water. On one occasion, when in a boat, we were so entangled by these shallows that we could hardly find our way. Nothing was visible but the flat beds of mud: the day was not very clear, and there was much refraction, or as the sailors expressed it, "things loomed high." The only object within our view which was not level was the horizon; rushes looked like bushes unsupported in the air, and water like mud-banks, and mud-banks like water.

We passed the night in Punta Alta, and I employed myself in searching for fossil bones; this point being a perfect catacomb for monsters of extinct races. The evening was perfectly calm and clear; the extreme monotony of the view gave it an interest even in the midst of mud-banks and gulls, sand-hillocks and solitary vultures. In riding back in the morning we came across a very fresh track of a Puma, but did not sueceed in finding it. We saw also a couple of Zorillos, or skunks, - - odious animals, which are far from uncommon. In general appearance the Zorillo resembles a polecat, but it is rather larger, and much thicker in proportion. Conscious of its power, it roams by day about the open plain, and fears neither dog nor man. If a dog is urged to the attack, its courage is instantly checked by a few drops of the fetid oil, which brings on violent sickness and running at the nose. Whatever is once polluted by it, is for ever useless. Azara says the smell can be perceived at a league clistant; more than once, when entering the harbour of Monte Video, the wind being off shore, we have perceived the odour on board the Beagle. Certain it is, that every animal most willingly makes room for the Zorillo. 


\section{CHAPTER V.}

Bahia Blanca-Geology-Numerous gigantic extinct Quadrupeds-Recent Extinction-Longevity of Species - Large Animals do not require a luxuriant vegetation-Southern Africa-Siberian Fossils-Two Species of Ostrich-Habits of Oven-bird-Armadilloes-Venomous Snake, Toad, Lizard-Hybernation of Animals-Habits of Sea-Pen-Indians Wars and Massacres-Arrow-head, antiquarian Relic.

\section{BAHIA BLANCA.}

THE Beagle arrived here on the 24th of August, and a week afterwards sailed for the Plata. With Captain Fitz Roy's consent I was left behind, to travel by land to Buenos Ayres. I will here add some observations, which were made during this visit and on a previous occasion, when the Beagle was employed in surveying the harbour.

The plain, at the distance of a few miles from the coast, belongs to the great Pampean formation, which consists in part of a reddish clay, and in part of a highly calcareous marly rock. Nearer the coast there are some plains formed from the wreck of the upper plain, and from mud, gravel, and sand thrown up by the sea during the slow elevation of the land, of which elevation we have evidence in upraised beds of recent shells, and in rounded pebbles of pumice scattered over the country. At Punta Alta we have a section of one of these later-formed little plains, which is highly interesting from the number and extraordinary character of the remains of gigantic land-animals embedded in it. These have been fully described by Professor Owen, in the Zoology of the voyage of the Beagle, and are deposited in the College of Surgeons. I will here give only a brief outline of their nature.

First, parts of three heads and other bones of the Megatherium, the huge dimensions of which are expressed by its name. Secondly, the Megalonyx, a great allied animal. 'Thirdly, the Scelidotherium, also an allied animal, of which I obtained a 
nearly perfect skeleton. It must have been as large as a rhinoceros: in the structure of its head it comes, according to $\mathrm{Mr}$. Owen, nearest to the Cape Ant-eater, but in some other respects it approaches to the armadilloes. Fourthly, the Mylodon Darwinii, a closely related genus of little inferior size. Fifthly, another gigantic edental quadruped. Sixthly, a large animal, with an osseous coat in compartments, very like that of an armadillo. Seventhly, an extinct kind of horse, to which I shall have again to refer. Eighthly, a tooth of a Pachydermatous animal, probably the same with the Macrauchenia, a huge beast with a long neck like a camel, which I shall also refer to again. Lastly, the Toxodon, perhaps one of the strangest animals ever discovered : in size it equalled an elephant or megatherium, but the structure of its teeth, as $\mathbf{M r}$. Owen states, proves indisputably that it was intimately related to the Gnawers, the order which, at the present day, includes most of the smallest quadrupeds: in many details it is allied to the Pachydermata: judging from the position of its eyes, ears, and nostrils, it was probably aquatic, like the Dugong and Manatee, to which it is also allied. How wonderfully are the different Orders, at the present time so well separated, blended together in different points of the structure of the Toxodon!

The remains of these nine great quadrupeds, and many detached bones were found embedded on the beach, within the space of about 200 yards square. It is a remarkable circumstance that so many different species should be found together; and it proves how numerous in kind the ancient inhabitants of this country must have been. At the distance of about thirty miles from P. Alta, in a cliff of red earth, I found several fragments of bones, some of large size. Among them were the teeth of a gnawer, equalling in size and closely resembling those of the Capybara, whose habits have been described; and therefore, probably, an aquatic animal. There was also part of the head of a Ctenomys; the species being different from the Tucutuco, but with a close general resemblance. The red earth, like that of the Pampas, in which these remains were embedded, contains, according to Professor Ehrenberg, eight fresh-water and one saltwater infusorial animalcule; therefore, probably, it was an estuary deposit.

The remains at Punta Alta were embedded in stratified gravel 
and reddish mud, just such as the sea might now wash up on a shallow bank. They were associated with twenty-three species of shells, of which thirteen are recent and four others very closely related to recent forms; whether the remaining ones are extinct or simply unknown, must be doubtful, as few collections of shells have been made on this coast. As, however, the recent species were embedded in nearly the same proportional numbers with those now living in the bay, I think there can be little doubt, that this accumulation belongs to a very late tertiary period. From the bones of the Scelidotherium, including even the knee-cap, being intombed in their proper relative positions, and from the osseous armour of the great armadillo-like animal being so well preserved, together with the bones of one of its legs, we may feel assured that these remains were fresh and united by their ligaments, when deposited in the gravel together with the shells. Hence we have good evidence that the above enumerated gigantic quadrupeds, more different from those of the present day than the oldest of the tertiary quadrupeds of Europe, lived whilst the sea was peopled with most of its present inhabitants; and we have confirmed that remarkable law so often insisted on by Mr. Lyell, namely, that the "longevity of the species in the mammalia is upon the whole inferior to that of the testacea."*

The great size of the bones of the Megatheroid animals, including the Megatherium, Megalonyx, Scelidotherium, and Mylodon, is truly wonderful. The habits of life of these animals were a complete puzzle to naturalists, until Professor Owen $\uparrow$ lately solved the problem with remarkable ingenuity. The teeth indicate, by their simple structure, that these Megatheroid animals lived on vegetable food, and probably on the leaves and small twigs of trees; their ponderous forms and great strong curved claws seem so little adapted for locomotion, that some eminent naturalists have actually believed, that, like the sloths, to which they are intimately related, they subsisted by climbing back downwards on trees, and feeding on the leaves. It was a bold,

* Principles of Geology, vol. iv. p. 40.

+ This theory was first developed in the Zoology of the Voyage of the Beagle, and subsequently in Professor Owen's Memoir on Mylodon robustus. 
not to say preposterous, idea to conceive even antediluvian trees, with branches strong enough to bear animals as large as elephants. Professor Owen, with far more probability, believes that, instead of climbing on the trees, they pulled the branches down to them, and tore up the smaller ones by the roots, and so fed on the leaves. The colossal breadth and weight of their hinder quarters, which can hardly be imagined without having been seen, become, on this view, of obvious service, instead of being an incumbrance: their apparent clumsiness disappears. With their great tails and their huge heels firmly fixed like a tripod on the ground, they could freely exert the full force of their most powerful arms and great claws. Strongly rooted, indeed, must that tree have been, which could have resisted such force! The Mylodon, moreover, was furnished with a long extensile tongue like that of the giraffe, which, by one of those beautiful provisions of nature, thus reaches with the aid of its long neck its leafy food. I may remark, that in Abyssinia the elephant, according to Bruce, when it cannot reach with its proboscis the branches, deeply scores with its tusks the trunk of the tree, up and down and all round, till it is sufficiently weakened to be broken down.

The beds including the above fossil remains, stand only from fifteen to twenty feet above the level of high-water; and hence the elevation of the land has been small (without there has been an intercalated period of subsidence, of which we have no evidence) since the great quadrupeds wandered over the sur. rounding plains; and the external features of the country must then have been very nearly the same as now. What, it may naturally be asked, was the character of the vegetation at that period; was the country as wretchedly sterile as it now is? As so many of the co-embedded shells are the same with those now living in the bay, I was at first inclined to think that the former vegetation was probably similar to the existing one; but this would have been an erroneous inference, for some of these same shells live on the luxuriant coast of Brazil ; and generally, the character of the inhabitants of the sea are useless as guides to judge of those on the land. Nevertheless, from the following considerations, I do not believe that the simple fact of many gigantic quadrupeds having lived on the plains round Bahia Blanca, is 
any sure guide that they formerly were clothed with a luxuriant vegetation: I have no doubt that the sterile country a little southward, near the Rio Negro, with its scattered thorny trees, would support many and large quadrupeds.

That large animals require a luxuriant vegetation, has been a general assumption which has passed from one work to another ; but I do not hesitate to say that it is completely false, and that it has vitiated the reasoning of geologists on some points of great interest in the ancient history of the world. The prejudice has probably been derived from India, and the Indian islands, where troops of elephants, noble forests, and impenetrable jungles, are associated together in every one's mind. If, however, we refer to any work of travels through the southern parts of Africa, we shall find allusions in almost every page either to the desert character of the country, or to the numbers of large animals inhabiting it. The same thing is rendered evident by the many engravings which have been published of various parts of the interior. When the Beagle was at Cape Town, I made an excursion of some days' length into the country, which at least was sufficient to render that which I had read more fully intelligible.

Dr. Andrew Smith, who, at the head of his adventurous party, has lately succeeded in passing the Tropic of Capricorn, informs me that, taking into consideration the whole of the southern part of Africa, there can be no doubt of its being a sterile country. On the southern and south-eastern coasts there are some fine forests, but with these exceptions, the traveller may pass for days together through open plains, covered by a poor and scanty vegetation. It is difficult to convey any accurate idea of degrees of comparative fertility; but it may be safely said that the amount of vegetation supported at any one time* by Great Britain, exceeds, perhaps even tenfold, the quantity on an equal area, in the interior parts of Southern Africa. The fact that bullock-waggons can travel in any direction, excepting near the coast, without more than occasionally half an hour's delay in cutting down bushes, gives, perhaps, a more definite

* I mean by this to exclude the total amount, which may have been successively produced and consumed during a given period. 
notion of the scantiness of the vegetation. Now, if we look to the animals inhabiting these wide plains, we shall find their numbers extraordinarily great, and their bulk immense. We must enumerate the elephant, three species of rhinoceros, and probably, according to Dr. Smith, two others, the hippopotamus, the giraffe, the bos caffer-as large as a full-grown bull, and the elan-but little less, two zebras, and the quaccha, two gnus, and several antelopes even larger than these latter animals. It may be supposed that although the species are numerous, the individuals of each kind are few. By the kindness of Dr. Smith, I am enabled to show that the case is very different. He informs me, that in lat. $24^{\circ}$, in one day's march with the bullock-wag . gons, he saw, without wandering to any great distance on either side, between one hundred and one hundred and fifty rhinoceroses, which belonged to three species: the same day he saw several herds of giraffes, amounting together to nearly a hundred; and that, although no elephant was observed, yet they are found in this district. At the distance of a little more than one hour's march from their place of encampment on the previous night, his party actually killed at one spot eight hippopotamuses, and saw many more. In this same river there were likewise crocodiles. Of course it was a case quite extraordinary, to see so many great animals crowded together, but it evidently proves that they must exist in great numbers. Dr. Smith describes the country passed through that day, as "being thinly covered with grass, and bushes about four feet high, and still more thinly with mimosa-trees." The waggons were not prevented travelling in a nearly straight line.

Besides these large animals, every one the least acquainted with the natural history of the Cape, has read of the herds of antelopes, which can be compared only with the flocks of migratory birds. The numbers indeed of the lion, panther, and hyæna, and the multitude of birds of prey, plainly speak of the abundance of the smaller quadrupeds: one evening seven lions were counted at the same time prowling round Dr. Smith's encampment. As this able naturalist remarked to me, the carnage each day in Southern Africa must indeed be terrific! I confess it is truly surprising how such a number of animals can find support in a country producing so little food. The larger qua- 
drupeds no doubt roam over wide tracts in search of it; and their food chiefly consists of underwood, which probably contains much nutriment in a small bulk. Dr. Smith also informs me that the vegetation has a rapid growth; no sooner is a part consumed, than its place is supplied by a fresh stock. There can be no doubt, however, that our ideas respecting the apparent amount of food necessary for the support of large quadrupeds are much exaggerated: it should have been remembered that the camel, an animal of no mean bulk, has always been considered as the emblem of the desert.

The belief that where large quadrupeds exist, the vegetation must necessarily be luxuriant, is the more remarkable, because the converse is far from true. Mr. Burchell observed to me that when entering Brazil, nothing struck him more forcibly than the splendour of the South American vegetation contrasted with that of South Africa, together with the absence of all large quadrupeds. In his Travels, ${ }^{*}$ he has suggested that the comparison of the respective weights (if there were sufficient data) of an equal number of the largest herbivorous quadrupeds of each country would be extremely curious. If we take on the one side, the elephant, $\dagger$ hippopotamus, giraffe, bos caffer, elan, certainly three, and probably five species of rhinoceros; and on the American side, two tapirs, the guanaco, three deer, the vicuna, peccari, capybara (after which we must choose from the monkeys to complete the number), and then place these two groups alongside each other, it is not easy to conceive ranks more disproportionate in size. After the above facts, we are compelled to

* Travels in the Interior of South Africa, vol. ii., p. 207.

$\dagger$ The elephant which was killed at Exeter Change was estimated (being partly weighed) at five tons and a half. The elephant actress, as I was informed, weighed one ton less; so that we may take five as the average of a full-grown elephant. I was told at the Surrey Gardens, that a hippopotamus which was sent to England cut up into pieces was estimated at three tons and a half; we will call it three. From these premises we may give three tons and a half to each of the five rhinoceroses; perhaps a ton to the giraffe, and half to the bos caffer as well as to the elan (a large ox weighs from 1200 to 1500 pounds). This will give an average (from the above estimates) of $2 \cdot 7$ of a ton for the ten largest herbivorous animals of Southern Africa. In South America, allowing 1200 pounds for the two tapirs together, 550 for the guanaco and vicuna, 500 for three deer, 300 for the capybara. peccari, and a monkey, we shall have an average of 250 pounds, which I believe is overstating the result. The ratio will therefore be as 6048 to 250 , or 24 to 1, for the ten largest animals from the two continents. 
conclude, against anterior probability, ${ }^{*}$ that among the mammalia there exists no close relation between the bulk of the species, and the quantity of the vegetation, in the countries which they inhabit.

With regard to the number of large quadrupeds, there certainly exists no quarter of the globe which will bear comparison with Southern Africa. After the different statements which have been given, the extremely desert character of that region will not be disputed. In the European division of the world, we must look back to the tertiary epochs, to find a condition of things among the mammalia, resembling that now existing at the Cape of Good Hope. Those tertiary epochs, which we are apt to consider as abounding to an astonishing degree with large animals, because we find the remains of many ages accumulated at certain spots, could hardly boast of more large quadrupeds than Southern Africa does at present. If we speculate on the condition of the vegetation during those epochs, we are at least bound so far to consider existing analogies, as not to urge as absolutely necessary a luxuriant vegetation, when we see a state of things so totally different at the Cape of Good Hope.

We know $\uparrow$ that the extreme regions of North America, many degrees beyond the limit where the ground at the depth of a few feet remains perpetually congealed, are covered by forests of large and tall trees. In a like manner, in Siberia, we have woods of birch, fir, aspen, and larch, growing in a latitudef $\left(64^{\circ}\right)$, where the mean temperature of the air falls below the freezing point, and where the earth is so completely frozen, that

* If we suppose the case of the discovery of a skeleton of a Greenland whale in a fossil state, not a single cetaceous animal being known to exist, what naturalist would have rentured conjecture on the possibility of a carcass so gigantic being supported on the minute crustacea and mollusca living
in the frozen seas of the extreme North?

† See Zoological Remarks to Capt. Back's Expedition, by Dr. Richardson. He says, "The subsoil north of latitude $56^{\circ}$ is perpetually frozen, the thaw on the coast not penetrating above three feet, and at Bear Lake, in latitude $64^{\circ}$, not more than twenty inches. The frozen substratum does not of itself destroy vegetation, fur forests flourish on the surface, at a distance from the

‡ See Humboldt, Fragmens Asiatiques, p. 386: Barton's Geography of Plants : and Malte Brun. In the latter work it is said that the limit of the growth of trees in Siberia may be drawn under the parallel of $70^{\circ}$. 
the carcass of an animal embedded in it is perfectly preserved. With these facts we must grant, as far as quantity alone of vegetation is concerned, that the great quadrupeds of the later tertiary epochs might, in most parts of Northern Europe and Asia, have lived on the spots where their remains are now found. I do not here speak of the kind of vegetation necessary for their support ; because, as there is evidence of physical changes, and as the animals have become extinct, so may we suppose that the species of plants have likewise been changed.

These remarks, I may be permitted to add, directly bear on the case of the Siberian animals preserved in ice. The firm conviction of the necessity of a vegetation possessing a character of tropical Inxuriance, to support such large animals, and the impossibility of reconciling this with the proximity of perpetual congelation, was one chief cause of the several theories of sudden revolutions of climate, and of overwhelming catastrophes, which were invented to account for their entombment. I am far from supposing that the climate has not changed since the period when those animals lived, which now lie buried in the ice. At present I only wish to show, that as far as quantity of food alone is concerned, the ancient rhinoceroses might have roamed over the steppes of central Siberia (the northern parts probably being under water) even in their present condition, as well as the living rhinoceroses and elephants over the Karros of Southern Africa.

I will now give an account of the habits of some of the more interesting birds which are common on the wild plains of Northern Patagonia; and first for the largest, or South American ostrich. The ordinary habits of the ostrich are familiar to every one. They live on vegetable matter, such as roots and grass; but at Bahia Blanca I have repeatedly seen three or four come down at low water to the extensive mud-banks which are then dry, for the sake, as the Gauchos say, of feeding on small fish. Although the ostrich in its habits is so shy, wary, and solitary, and although so fleet in its pace, it is caught without much difficulty by the Indian or Gaucho armed with the bolas. When several horsemen appear in a semicircle, it becomes confounded, and does not know which way to escape. They generally prefer 
running against the wind; yet at the first start they expand their wings, and like a vessel make all sail. On one fine hot day I saw several ostriches enter a bed of tall rushes, where they squatted concealed, till quite closely approached. It is not generally known that ostriches readily take to the water. Mr. King informs me that at the Bay of San Blas, and at Port Valdes in Patagonia, he saw these birds swimming several times from island to island. They ran into the water both when driven down to a point, and likewise of their own accord when not frightened: the distance crossed was about two hundred yards. When swimming, very little of their bodies appear above water; their necks are extended a little forward, and their progress is slow. On two occasions I saw some ostriches swimming across the Santa Cruz river, where its course was about four hundred yards wide, and the stream rapid. Captain Sturt, ${ }^{*}$ when descending the Murrumbidgee, in Australia, saw two emus in the act of swimming.

The inhabitants of the country readily distinguish, even at a distance, the cock bird from the hen. The former is larger and darker-coloured, $\uparrow$ and has a bigger head. The ostrich, I believe the cock, emits a singular, deep-toned, hissing note: when first I heard it, standing in the midst of some sand-hillocks, I thought it was made by some wild beast, for it is a sound that one cannot tell whence it comes, or from how far distant. When we were at Bahia Blanca in the months of September and October, the eggs, in extraordinary numbers, were found all over the country. They lie either scattered and single, in which case they are never hatched, and are called by the Spaniards huachos; or they are collected together into a shallow excavation, which forms the nest. Out of the four nests which I saw, three contained twentytwo eggs each, and the fourth twenty-seven. In one day's hunting on horseback sixty-four eggs were found; forty-four of these were in two nests, and the remaining twenty, scattered huachos. The Gauchos unanimously affirm, and there is no reason to doubt their statement, that the male bird alone hatches the eggs, and for some time afterwards accompanies the young.

- Sturt's Travels, vol. ii. p. 74 .

$\dagger$ A Gaucho assured me that he had once seen a snow-white or Albino variety, and that it was a most beautiful bird. 
The cock when on the nest lies very close; I have myself almost ridden over one. It is asserted that at such times they are occasionally fierce, and even dangerous, and that they have been known to attack a man on horseback, trying to kick and leap on him. My informer pointed out to me an old man, whom he had seen much terrified by one chasing him. I observe in Burchell's travels in South Africa, that he remarks, "Having killed a male ostrich, and the feathers being dirty, it was said by the Hottentots to be a nest bird." I understand that the male emu in the Zoological Gardens takes charge of the nest: this habit, therefore, is common to the family.

The Gauchos unanimously affirm that several females lay in one nest. I have been positively told that four or five hen birds have been watched to go in the middle of the day, one after the other, to the same nest. I may add, also, that it is believed in Africa, that two or more females lay in one nest.* Although this habit at first appears very strange, I think the cause may be explained in a simple manner. The number of eggs in the nest varies from twenty to forty, and even to fifty ; and according to Azara, sometimes to seventy or eighty. Now although it is most probable, from the number of eggs found in one district being so extraordinarily great in proportion to the parent birds, and likewise from the state of the ovarium of the hen, that she may in the course of the season lay a large number, yet the time required must be very long. Azara states, $\uparrow$ that a female in a state of domestication laid seventeen eggs, each at the interval of three days one from another. If the hen was obliged to hatch her own eggs, before the last was laid the first probably would be addled; but if each laid a few eggs at successive periods, in different nests, and several hens, as is stated to be the case, combined together, then the eggs in one collection would be nearly of the same age. If the number of eggs in one of these nests is, as I believe, not greater on an average than the number laid by one female in the season, then there must be as many nests as females, and each cock bird will have its fair share of the labour of incubation; and that during a period when the

* Burchell's Travels, vol. i. p. 280.

† Azara, vol. iv. p. 173. 
females probably could not sit, from not having finished laying.* I have before mentioned the great numbers of huachos, or deserted eggs; so that in one day's hunting twenty were found in this state. It appears odd that so many should be wasted. Does it not arise from the difficulty of several females associating together, and finding a male ready to undertake the office of incubation? It is evident that there must at first be some degree of association between at least two females; otherwise the eggs would remain scattered over the wide plains, at distances far too great to allow of the male collecting them into one nest: some authors have believed that the scattered eggs were deposited for the young birds to feed on. This can hardly be the case in America, because the huachos, although often found addled and putrid, are generally whole.

When at the Rio Negro in Northern Patagonia, I repeatedly heard the Gauchos talking of a very rare bird which they called Avestruz Petise. They described it as being less than the common ostrich (which is there abundant), but with a very close general resemblance. They said its colour was dark and mottled, and that its legs were shorter, and feathered lower down than those of the common ostrich. It is more easily caught by the bolas than the other species. The few inhabitants who had seen both kinds, affirmed they could distinguish them apart from a long distance. The eggs of the small species appeared, however, more generally known; and it was remarked, with surprise, that they were very little less than those of the Rhea, but of a slightly different form, and with a tinge of pale blue. This species occurs most rarely on the plains bordering the Rio Negro; but about a degree and a half further south they are tolerably abundant. When at Port Desire, in Patagonia (lat. 48 $)$, Mr. Martens shot an ostrich; and I looked at it, forgetting at the moment, in the most unaccountable manner, the whole subject of the Petises, and thought it was a not full-grown bird of the common sort. It was cooked and eaten before my memory returned.

- Lichtenstein, however, asserts (Travels, vol.ii.p. 25) that the hens begin sitting when they have laid ten or twelve eggs; and that they continue laying, I presume, in another nest. This appears to me very improbable. He asserts that four or five hens associate for incubation with one cock, who
sits only at night. 
Fortunately the head, neck, legs, wings, many of the larger feathers, and a large part of the skin, had been preserved; and from these a very nearly perfect specimen has been put together, and is now exhibited in the museum of the Zoological Society. Mr. Gould, in describing this new species, has done me the honour of calling it after my name.

Among the Patagonian Indians in the Strait of Magellan, we found a half Indian, who had lived some years with the tribe, but had been born in the northern provinces. I asked him if he had ever heard of the Avestruz Petise? He answered by saying, "Why there are none others in these southern countries." $\mathrm{He}$ informed me that the number of eggs in the nest of the petise is considerably less than in that of the other kind, namely, not more than fifteen on an average; but he asserted that more than one female deposited them. At Santa Cruz we saw several of these birds. They were excessively wary: I think they could see a person approaching when too far off to be distinguished themselves. In ascending the river few were seen; but in our quiet and rapid descent, many, in pairs and by fours or fives, were observed. It was remarked that this bird did not expand its wings, when first starting at full speed, after the manner of the northern kind. In conclusion I may observe, that the Struthio rhea inhabits the country of La Plata as far as a little south of the Rio Negro in lat. $41^{\circ}$, and that the Struthio Darwinii takes its place in Southern Patagonia; the part about the Rio Negro being neutral territory. M. A. d'Orbigny,* when at the Rio Negro, made great exertions to procure this bird, but never had the good fortune to succeed. Dobrizhoffer $\dagger$ long ago was aware of there being two kinds of ostriches; he says, "You must know, moreover, that Emus differ in size and habits in different tracts of land; for those that inhabit the plains of Buenos Ayres and Tucuman are larger, and have black, white, and gray feathers; those near to the Strait of Magellan are smaller and more beautiful, for their white feathers are tipped

* When at the Rio Negro, we heard much of the indefatigable labours of this naturalist. M. Alcide d'Orbigny, during the years 1825 to 1833 , traversed several large portions of South America, and has made a collection, and is now publishing the results on a scale of magnificence, which at once places himself in the list of American travellers second only to Humboldt.

$\dagger$ Account of the Abipones, A.D. 1749, vol. i. (English translation), p. 314. 
with black at the extremity, and their black ones in like manner terminate in white."

A very singular little bird, Tinochorus rumicivorus, is here common : in its habits and general appearance, it nearly equally partakes of the characters, different as they are, of the quail and snipe. The Tinochorus is found in the whole of southern South America, wherever there are sterile plains, or open dry pasture land. It frequents in pairs or small flocks the most desolate places, where scarcely another living creature can exist. Upon being approached they squat close, and then are very difficult to be distinguished from the ground. When feeding they walk rather slowly, with their legs wide apart. They dust themselves in roads and sandy places, and frequent particular spots, where they may be found day after day: like partridges, they take wing in a flock. In all these respects, in the muscular gizzard adapted for vegetable food, in the arched beak and fleshy nostrils, short legs and form of foot, the Tinochorus has a close affinity with quails. But as soon as the bird is seen flying, its whole appearance changes; the long pointed wings, so different from those in the gallinaceous order, the irregular manner of flight, and plaintive cry uttered at the moment of rising, recal the idea of a snipe. The sportsmen of the Beagle unanimously called it the short-billed snipe. To this genus, or rather to the family of the Waders, its skeleton shows that it is really related.

The Tinochorus is closely related to some other South American birds. Two species of the genus Attagis are in almost every respect ptarmigans in their habits; one lives in Tierra del Fuego, above the limits of the forest land; and the other just beneath the snow-line on the Cordillera of Central Chile. A bird of another closely allied genus, Chionis alba, is an inhabitant of the antarctic regions; it feeds on sea-weed and shells on the tidal rocks. Although not web-footed, from some unaccountable habit, it is frequently met with far out at sea. This small family of birds is one of those which, from its varied relations to other families, although at present offering only difficulties to the systematic naturalist, ultimately may assist in revealing the grand scheme, common to the present and past ages, on which organized beings have been created. 
The genus Furnarius contains several species, all small birds, living on the ground, and inhabiting open dry countries. In structure they cannot be compared to any European form. Ornithologists have generally included them among the creepers, although opposed to that family in every habit. The best known species is the common oven-bird of La Plata, the Casara or housemaker of the Spaniards. The nest, whence it takes its name, is placed in the most exposed situations, as on the top of a post, a bare rock, or on a cactus. It is composed of mud and bits of straw, and has strong thick walls : in shape it precisely resembles an oven, or depressed beehive. The opening is large and arched, and directly in front, within the nest, there is a partition, which reaches nearly to the roof, thus forming a passage or antechamber to the true nest.

- Another and smaller species of Furnarius (F. cunicularius), resembles the oven-bird in the general reddish tint of its plumage, in a peculiar shrill reiterated cry, and in an odd manner of running by starts. From its affinity, the Spaniards call it Casarita (or little housebuilder), although its nidification is quite different. The Casarita builds its nest at the bottom of a narrow cylindrical hole, which is said to extend horizontally to nearly six feet under ground. Several of the country people told me, that when boys, they had attempted to dig out the nest, but had scarcely ever succeeded in getting to the end of the passage. The bird chooses any low bank of firm sandy soil by the side of a road or stream. Here (at Bahia Blanca) the walls round the houses are built of hardened mud; and I noticed that one, which enclosed a courtyard where I lodged, was bored through by round holes in a score of places. On asking the owner the cause of this, he bitterly complained of the little casarita, several of which I afterwards observed at work. It is rather curious to find how incapable these birds must be of acquiring any notion of thickness, for although they were constantly flitting over the low wall, they continued vainly to bore through it, thinking it an excellent bank for their nests. I do not doubt that each bird, as often as it came to daylight on the opposite side, was greatly surprised at the marvellous fact.

I have already mentioned nearly all the mammalia common in this country. Of armadilloes three species occur, namely, 
the Dasypus minutus or pichy, the D. villosus or peludo, and the apar. The first extends ten degrees further south than any other kind : a fourth species, the Mulita, does not come as far south a Bahia Blanca. The four species have nearly similar habits; the peludo, however, is nocturnal, while the others wander by day over the open plains, feeding on beetles, larvæ, roots, and even small snakes. The apar, commonly called mataco, is remarkable by having only three moveable bands; the rest of its tesselated covering being nearly inflexible. It has the power of rolling itself into a perfect sphere, like one kind of English woodlouse. In this state it is safe from the attack of dogs; for the dog not being able to take the whole in its mouth, tries to bite one side, and the ball slips away. The smooth hard covering of the mataco offers a better defence than the sharp spines of the hedgehog. The pichy prefers a very dry soil; and the sand-dunes near the coast, where for many months it can never taste water, is its favourite resort: it often tries to escape notice, by squatting close to the ground. In the course of a day's ride, near Bahia Blanca, several were generally met with. The instant one was perceived, it was necessary, in order to catch it, almost to tumble off one's horse; for in soft soil the animal burrowed so quickly, that its hinder quarters would almost disappear before one could alight. It seems almost a pity to kill such nice little animals, for as a Gaucho said, while sharpening his knife on the back of one, "Son tan mansos" (they are so quiet).

Of reptiles there are many kinds: one snake (a Trigonocephalus, or Cophias), from the size of the poison channel in its fangs, must be very deadly. Cuvier, in opposition to some other naturalists, makes this a sub-genus of the rattlesnake, and intermediate between it and the viper. In confirmation of this opinion, I observed a fact, which appears to me very curious and instructive, as showing how every character, even though it may be in some degree independent of structure, has a tendency to vary by slow degrees. The extremity of the tail of this snake is terminated by a point, which is very slightly enlarged; and as the animal glides along, it constantly vibrates the last inch; and this part striking against the dry grass and brushwood, produces a rattling noise, which can be distinctly heard at the dis- 
tance of six feet. As often as the animal was irritated or surprised, its tail was shaken; and the vibrations were extremely rapid. Even as long as the body retained its irritability, a tendency to this habitual movement was evident. This Trigonocephalus has, therefore, in some respects the structure of a viper, with the habits of a rattlesnake : the noise, however, being produced by a simpler device. The expression of this snake's face was hideous and fierce; the pupil consisted of a vertical slit in a mottled and coppery iris; the jaws were broad at the base, and the nose terminated in a triangular projection. I do not think I ever saw any thing more ugly, excepting, perhaps, some of the vampire bats. I imagine this repulsive aspect originates from the features being placed in positions, with respect to each other, somewhat proportional to those of the human face; and thus we obtain a scale of hideousness.

Amongst the Batrachian reptiles, I found only one little toad (Phryniscus nigricans), which was most singular from its colour. If we imagine, first, that it had been steeped in the blackest ink, and then, when dry, allowed to crawl over a board, freshly painted with the brightest vermilion, so as to colour the soles of its feet and parts of its stomach, a good idea of its appearance will be gained. If it had been an unnamed species, surely it ought to have been called Diabolicus, for it is a fit toad to preach in the ear of Eve. Instead of being nocturnal in its habits, as other toads are, and living in damp obscure recesses, it crawls during the heat of the day about the dry sand-hillocks and arid plains, where not a single drop of water can be found. It must necessarily depend on the dew for its moisture; and this probably is absorbed by the skin, for it is known, that these reptiles possess great powers of cutaneous absorption. At Maldonado, I found one in a situation nearly as dry as at Bahia Blanca, and thinking to give it a great treat, carried it to a pool of water; not only was the little animal unable to swim, but, I think without help it would soon have been drowned.

Of lizards there were many kinds, but only one (Proctotretus multimaculatus) remarkable from its habits. It lives on the bare sand near the sea coast, and from its mottled colour, the brownish scales being speckled with white, yellowish red, and dirty blue, can hardly be distinguished from the surrounding 
surface. When frightened, it attempts to avoid discovery by feigning death, with outstretched legs, depressed body, and closed eyes : if further molested, it buries itself with great quickness in the loose sand. This lizard, from its flattened body and short legs, cannot run quickly;

I will here add a few remarks on the hybernation of animals in this part of South America. When we first arrived at Bahia Blanca, September 7th, 1832, we thought nature had granted scarcely a living creature to this sandy and dry country. By digging, however, in the ground, several insects, large spiders, and lizards were found in a half torpid state. On the 15th, a few animals began to appear, and by the 18th (three days from the equinox), every thing announced the commencement of spring. 'The plains were ornamented by the flowers of a pink wood-sorrel, wild peas, œnotheræ, and geraniums ; and the birds began to lay their eggs. Numerous Lamellicorn and Heteromerous insects, the latter remarkable for their deeply sculptured bodies, were slowly crawling about; while the lizard tribe, the constant inhabitants of a sandy soil, darted about in every direction. During the first eleven days, whilst nature was dormant, the mean temperature taken from observations made every two hours on board the Beagle, was $51^{\circ}$; and in the middle of the day the thermometer seldom ranged above $55^{\circ}$. On the eleven succeeding days, in which all living things became so animated, the mean was $58^{\circ}$, and the range in the middle of the day between sixty and seventy. Here then an increase of seven degrees in mean temperature, but a greater one of extreme heat, was sufficient to awake the functions of life. At Monte Video, from which we had just before sailed, in the twenty-three days included between the 26th of July and the 19th of August, the mean temperature from 276 observations was $58^{\circ} .4$; the mean hottest day being $65^{\circ} .5$, and the coldest $46^{\circ}$. The lowest point to which the thermometer fell was $41^{\circ} .5$, and occasionally in the middle of the day it rose to $69^{\circ}$ or $70^{\circ}$. Yet with this high temperature, almost every beetle, several genera of spiders, snails, and land-shells, toads and lizards were all lying torpid beneath stones. But we have seen that at Bahia Blanca, which is four degrees southward, and therefore with a climate only a very little colder, this same temperature with a rather less ex- 
treme heat, was sufficient to awake all orders of animated beings. This shows how nicely the stimulus required to arouse hybernating animals is governed by the usual climate of the district, and not by the absolute heat. It is well known that within the tropies, the hybernation, or more properly æstivation, of animals is determined not by the temperature, but by the times of drought. Near Rio de Janeiro, I was at first surprised to observe, that, a few days after some little depressions had been filled with water, they were peopled by numerous full-grown shells and beetles, which must have been lying dormant. Humboldt has related the strange accident of a hovel having been erected over a spot where a young crocodile lay buried in the hardened mud. He adds, "The Indians often find enormous boas, which they call Uji, or water serpents, in the same lethargic state. To reanimate them, they must be irritated or wetted with water."

I will only mention one other animal, a zoophyte (I believe Virgularia Patagonica) a kind of sea-pen. It consists of a thin, straight, fleshy stem, with alternate rows of polypi on each side, and surrounding an elastic stony axis, varying in length from eight inches to two feet. The stem at one extremity is truncate, but at the other is terminated by a vermiform fleshy appendage. The stony axis which gives strength to the stem may be traced at this extremity into a mere vessel filled with granular matter. At low water hundreds of these zoophytes might be seen, projecting like stubble, with the truncate end upwards, a few inches above the surface of the muddy sand. When touched or pulled they suddenly drew themselves in with force, so as nearly or quite to disappear. By this action, the highly elastic axis must be bent at the lower extremity, where it is naturally slightly curved; and I imagine it is by this elasticity alone that the zoophyte is enabled to rise again through the mud. Each polypus, though closely united to its brethren, has a distinct mouth, body, and tentacula. Of these polypi, in a large specimen, there must be many thousands; yet we see that they act by one movement: they have also one central axis connected with a system of obscure circulation, and the ova are produced in an organ distinct from the separate individuals.* Well may one be

* The cavities leading from the fleshy compartments of the extremity, 
allowed to ask, what is an individual? It is always interesting to discover the foundation of the strange tales of the old voyagers; and I have no doubt but that the habits of this Virgularia explain one such case. Captain Lancaster, in his voyage* in 1601, narrates that on the sea-sands of the Island of Sombrero, in the East Indies, he "found a small twig growing up like a young tree, and on offering to pluck it up it shrinks down to the ground, and sinks, unless held very hard. On being plucked up, a great worm is found to be its root, and as the tree groweth in greatness, so doth the worm diminish; and as soon as the worm is entirely turned into a tree it rooteth in the earth, and so becomes great. This transformation is one of the strangest wonders that I saw in all my travels : for if this tree is plucked up, while young, and the leaves and bark stripped off, it becomes a hard stone when dry, much like white coral : thus is this worm twice transformed into different natures. Of these we gathered and brought home many."

During my stay at Bahia Blanca, while waiting for the Beagle, the place was in a constant state of excitement, from rumours of wars and victories, between the troops of Rosas and the wild Indians. One day an account came that a small party forming one of the postas on the line to Buenos Ayres, had been found all murdered. The next day three hundred men arrived from the Colorado, under the command of Commandant Miranda. A large portion of these men were Indians (mansos, or tame), belonging to the tribe of the Cacique Bernantio. They passed

were filled with a yellow pulpy matter, which, examined under a microscope, presented an extraordinary appearance. The mass consisted of rounded, semi-transparent, irregular grains, aggregated together into par-
ticles of various sizes. All such particles, and the the power of rapid movement; generally revolvingarate grains, possessed the power of rapid movement; generally revolving around different axes, power, but even with the highest its cause could not be perceived. very different from the circulation of the fluid in the elastic bag, containing the thin extremity of the axis. On other occasions, when dissecting small marine animals beneath the microscope, I have seen particles of pulpy matter, some of large size, as soon as they were disengaged, commence revolving. I have imagined, I know not with how much truth, that this granulo-
pulpy matter was in process of being converted into ova. Certainly in this
zoophyte such appeared to be the case. zoophyte such appeared to be the case.

* Kerr's Collection of Voyages, vol. viii. p. 119. 
the night here; and it was impossible to conceive any thing more wild and savage than the scene of their bivouac. Some drank till they were intoxicated; others swallowed the steaming blood of the cattle slaughtered for their suppers, and then, being sick from drunkenness, they cast it up again, and were besmeared with filth and gore.

Nam simul expletus dapibus, vinoque sepultus

Cervicem inflexam posuit, jacuitque per antrum

Immensus, saniem eructans, ac frusta cruenta

Per somnum commixta mero.

In the morning they started for the scene of the murder, with orders to follow the "rastro," or track, even if it led them to Chile. We subsequently heard that the wild Indians had escaped into the great Pampas, and from some cause the track had been missed, One glance at the rastro tells these people a whole history. Supposing they examine the track of a thousand horses, they will soon guess the number of mounted ones by seeing how many have cantered; by the depth of the other impressions, whether any horses were loaded with cargoes; by the irregularity of the footsteps, how far tired; by the manner in which the food has been cooked, whether the pursued travelled in haste; by the general appearance, how long it has been since they passed. They consider a rastro of ten days or a fortnight, quite recent enough to be hunted out. We also heard that Miranda struck from the west end of the Sierra Ventana, in a direct line to the island of Cholechel, situated seventy leagues up the Rio Negro. This is a distance of between two and three hundred miles, through a country completely unknown. What other troops in the world are so independent? With the sun for their guide, mares' flesh for food, their saddle-cloths for beds,-as long as there is a little water, these men would penetrate to the end of the world.

A few days afterwards I saw another troop of these bandittilike soldiers start on an expedition against a tribe of Indians at the small Salinas, who had been betrayed by a prisoner cacique. The Spaniard who brought the orders for this expedition was a very intelligent man. He gave me an account of the last engagement at which he was present. Some Indians, who had been taken prisoners, gave information of a tribe living north of the 
Colorado. Two hundred soldiers were sent; and they first discovered the Indians by a cloud of dust from their horses' feet, as they chanced to be travelling. The country was mountainous and wild, and it must have been far in the interior, for the Cordillera were in sight. The Indians, men, women, and children, were about one hundred and ten in number, and they were nearly all taken or killed, for the soldiers sabre every man. The Indians are now so terrified that they offer no resistance in a body, but each flies, neglecting even his wife and children; but when overtaken, like wild animals, they fight against any number to the last moment. One dying Indian seized with his teeth the thumb of his adversary, and allowed his own eye to be forced out sooner than relinquish his hold. Another, who was wounded, feigned death, keeping a knife ready to strike one more fatal blow. My informer said, when he was pursuing an Indian, the man cried out for mercy, at the same time that he was covertly loosing the bolas from his waist, meaning to whirl it round his head and so strike his pursuer. "I however struck him with my sabre to the ground, and then got off my horse, and cut his throat with my knife." This is a dark picture; but how much more shocking is the unquestionable fact, that all the women who appear above twenty years old are massacred in cold blood! When I exclaimed that this appeared rather inhuman, he answered, "Why, what can be done? they breed so !"

Every one here is fully convinced that this is the most just war, because it is against barbarians. Who would believe in this age that such atrocities could be committed in a Christian civilized country? The children of the Indians are saved, to be sold or given away as servants, or rather slaves for as long a time as the owners can make them believe themselves slaves; but I believe in their treatment there is little to complain of.

In the battle four men ran away togther. They were pursued, one was killed, and the other three were taken alive. They turned out to be messengers or ambassadors from a large body of Indians, united in the common cause of defence, near the Cordillera. The tribe to which they had been sent was on the point of holding a grand council; the feast of mare's flesh was ready, and the dance prepared: in the morning the ambassadors were to have returned to the Cordillera. They were remarkably fine 
men, very fair, above six feet high, and all under thirty years of age. The three survivors of course possessed very valuable information; and to extort this they were placed in a line. The two first being questioned, answered, "No sé" (I do not know), and were one after the other shot. The third also said "No sé ;" adding, "Fire, I am a man, and can die!" Not one syllable would they breathe to injure the united cause of their country! The conduct of the above-mentioned cacique was very different: he saved his life by betraying the intended plan of warfare, and the point of union in the Andes. It was believed that there were already six or seven hundred Indians together, and that in summer their numbers would be doubled. Ambassadors were to have been sent to the Indians at the small Salinas, near Bahia Blanca, whom I have mentioned that this same cacique had betrayed. The communication, therefore, between the Indians, extends from the Cordillera to the coast of the Atlantic.

General Rosas's plan is to kill all stragglers, and having driven the remainder to a common point, to attack them in a body, in the summer, with the assistance of the Chilenos. This operation is to be repeated for three successive years. I imagine the summer is chosen as the time for the main attack, because the plains are then without water, and the Indians can only travel in particular directions. The escape of the Indians to the south of the Rio Negro, where in such a vast unknown country they would be safe, is prevented by a treaty with the Tehuelches to this effect; - - that Rosas pays them so much to slaughter every Indian who passes to the south of the river, but if they fail in so doing, they themselves are to be exterminated. The war is waged chiefly against the Indians near the Cordillera; for many of the tribes on this eastern side are fighting with Rosas. The general, however, like Lord Chesterfield, thinking that his friends may in a future day become his enemies, always places them in the front ranks, so that their numbers may be thinned. Since leaving South America we have heard that this war of extermination completely failed.

Among the captive girls taken in the same engagement, there were two very pretty Spanish ones, who had been carried away by the Indians when young, and could now only speak the Indian tongue. From their account they must have come from 
Salta, a distance in a straight line of nearly one thousand miles. This gives one a grand idea of the immense territory over which the Indians roam: yet, great as it is, I think there will not, in another half-century, be a wild Indian northward of the Rio Negro. The warfare is too bloody to last; the Christians killing every Indian, and the Indians doing the same by the Christians. It is melancholy to trace how the Indians have given way before the Spanish invaders. Schirdel* says that in 1535, when Buenos Ayres was founded, there were villages containing two and three thousand inhabitants. Even in Falconer's time (1750) the Indians made inroads as far as Luxan, Areco, and Arrecife, but now they are driven beyond the Salado. Not only have whole tribes been exterminated, but the remaining Indians have become more barbarous : instead of living in large villages, and being employed in the arts of fishing, as well as of the chace, they now wander about the open plains, without home or fixed occupation.

I heard also some account of an engagement which took place, a few weeks previously to the one mentioned, at Cholechel. This is a very important station on account of being a pass for horses; and it was, in consequence, for some time the headquarters of a division of the army. When the troops first arrived there they found a tribe of Indians, of whom they killed twenty or thirty. The cacique escaped in a manner which astonished every one. The chief Indians always have one or two picked horses, which they keep ready for any urgent occasion. On one of these, an old white horse, the cacique sprung, taking with him his little son. The horse had neither saddle nor bridle. To avoid the shots, the Indian rode in the peculiar method of his nation; namely, with an arm round the horse's neck, and one leg only on its back. Thus hanging on one side, he was seen patting the horse's head, and talking to him. The pursuers urged every effort in the chace; the Commandant three times changed his horse, but all in vain. The old Indian father and his son escaped, and were free. What a fine picture one can form in one's mind, - the naked, bronze-like figure of the

${ }^{*}$ Purchas's Collection of Voyages. I believe the date was really
1537. 
old man with his little boy, riding like a Mazeppa on the white horse, thus leaving far behind him the host of his pursuers!

I saw one day a soldier striking fire with a piece of flint, which I immediately recognised as having been a part of the head of an arrow. He told me it was found near the island of Cholechel, and that they are frequently picked up there. It was between two and three inches long, and therefore twice as large as those now used in Tierra del Fuego: it was made of opake cream-coloured flint, but the point and barbs had been intentionally broken off. It is well known that no Pampas Indians now use bows and arrows. I believe a small tribe in Banda Oriental must be excepted; but they are widely separated from the Pampas Indians, and border close on those tribes that inhabit the forest, and live on foot. It appears, therefore, that these arrow-heads are antiquarian* relics of the Indians, before the great change in habits consequent on the introduction of the horse into South America.

- Azara has even doubted whether the Pampas Indians ever used bows. 


\section{CHAPTER VI.}

Set out for Buenos Ayres-Rio Sauce-Sierra Ventana-Third PostaDriving Horses-Bolas--Partridges and Foxes-Features of the CountryLong-legged Plover-Teru-tero-Hail-storm-Natural Enclosures in the Sierra Tapalguen-Flesh of Puma-Meat Diet-Guardia del MonteEffects of Cattle on the Vegetation-Cardoon-Buenos Ayres-Corral where Cattle are slaughtered.

\section{BAHIA BLANCA TO BUENOS AYRES.}

September 8th.-I hired a Gaucho to accompany me on my ride to Buenos Ayres, though with some difficulty, as the father of one man was afraid to let him go, and another, who seemed willing, was described to me as so fearful, that I was afraid to take him, for I was told that even if he saw an ostrich at a distance, he would mistake it for an Indian, and would fly like the wind away. The distance to Buenos Ayres is about four hundred miles, and nearly the whole way through an uninhabited country. We started early in the morning; ascending a few hundred feet from the basin of green turf on which Bahia Blanca stands, we entered on a wide desolate plain. It consists of a crumbling argillaceo-calcareous rock, which, from the dry nature of the climate, supports only scattered tufts of withered grass, without a single bush or tree to break the monotonous uniformity. The weather was fine, but the atmosphere remarkably hazy; I thought the appearance foreboded a gale, but the Gauchos said it was owing to the plain, at some great distance in the interior, being on fire. After a long gallop, having changed horses twice, we reached the Rio Sauce : it is a deep, rapid, little stream, not above twenty-five feet wide. The second posta on the road to Buenos Ayres stands on its banks; a little above there is a ford for horses, where the water does not reach to the horses' belly; but from that point, in its course to the sea, it is quite impassable, and hence makes a most useful barrier against the Indians. 
Insignificant as this stream is, the Jesuit Falconer, whose information is generally so very correct, figures it as a considerable river, rising at the foot of the Cordillera. With respect to its source, I do not doubt that this is the case; for the Gauchos assured me, that in the middle of the dry summer, this stream, at the same time with the Colorado, has periodical floods; which can only originate in the snow melting on the Andes. It is extremely improbable that a stream so small as the Sauce then was, should traverse the entire width of the continent ; and indeed, if it were the residue of a large river, its waters, as in other ascertained cases, would be saline. During the winter we must look to the springs round the Sierra Ventana as the source of its pure and limpid stream. I suspect the plains of Patagonia, like those of Australia, are traversed by many watercourses, which only perform their proper parts at certain periods. Probably this is the ease with the water which flows into the head of Port Desire, and likewise with the Rio Chupat, on the banks of which masses of highly cellular scoriæ were found by the officers employed in the survey.

As it was early in the afternoon when we arrived, we took fresh horses, and a soldier for a guide, and started for the Sierra de la Ventana. This mountain is visible from the anchorage at Bahia Blanca; and Capt. Fitz Roy calculates its height to be 3340 feet-an altitude very remarkable on this eastern side of the continent. I am not aware that any foreigner, previous to my visit, had ascended this mountain; and indeed very few of the soldiers at Bahia Blanca knew anything about it. Hence we heard of beds of coal, of gold and silver, of caves, and of forests, all of which inflamed my curiosity, only to disappoint it. The distance from the posta was about six leagues, over a level plain of the same character as before. The ride was, however, interesting, as the mountain began to show its true form. When we reached the foot of the main ridge, we had much difficulty in finding any water, and we thought we should have been obliged to have passed the night without any. At last we discovered some by looking close to the mountain, for at the distance even of a few hundred yards, the streamlets were buried and entirely lost in the friable calcareous stone and loose detritus. I do not think Nature ever made a more solitary, desolate pile of rock; 
-it well deserves its name of Hurtado, or separated. The mountain is steep, extremely rugged, and broken, and so entirely destitute of trees, and even bushes, that we actually could not make a skewer to stretch out our meat over the fire of thistlestalks.* The strange aspect of this mountain is contrasted by the sea-like plain, which not only abuts against its steep sides, but likewise separates the parallel ranges. The uniformity of the colouring gives an extreme quietness to the view ;- the whitish grey of the quartz rock, and the light brown of the withered grass of the plain, being unrelieved by any brighter tint. From custom, one expects to see in the neighbourhood of a lofty and bold mountain, a broken country strewed over with huge fragments. Here nature shows that the last movement before the bed of the sea is changed into dry land may sometimes be one of tranquillity. Under these circumstances I was curious to observe how far from the parent rock any pebbles could be found. On the shores of Bahia Blanca, and near the settlement, there were some of quartz, which certainly must have come from this source: the distance is forty-five miles.

The dew, which in the early part of the night wetted the saddle-cloths under which we slept, was in the morning frozen. The plain, though appearing horizontal, had insensibly sloped up to a height of between 800 and 900 feet above the sea. In the morning (9th of September) the guide told me to ascend the nearest ridge, which he thought would lead me to the four peaks that crown the summit. The climbing up such rough rocks was very fatiguing; the sides were so indented, that what was gained in one five minutes was often lost in the next. At last, when I reached the ridge, my disappointment was extreme in finding a precipitous valley as deep as the plain, which cut the chain transversely in two, and separated me from the four points. This valley is very narrow, but flat-bottomed, and it forms a fine horse-pass for the Indians, as it connects the plains on the northern and southern sides of the range. Having descended, and while crossing it, I saw two horses grazing: I immediately hid myself in the long grass, and began to reconnoitre; but as I could see no signs of Indians I proceeded cautiously on my

* I call these thistle-stalks for the want of a more correct name. I believe it is a species of Eryngium. 
second ascent. It was late in the day, and this part of the mountain, like the other, was steep and rugged. I was on the top of the second peak by two o'clock, but got there with extreme difficulty; every twenty yards I had the cramp in the upper part of both thighs, so that I was afraid I should not have been able to have got down again. It was also necessary to return by another road, as it was out of the question to pass over the saddle-back. I was therefore obliged to give up the two higher peaks. Their altitude was but little greater, and every purpose of geology had been answered; so that the attempt was not worth the hazard of any further exertion. I presume the cause of the cramp was the great change in the kind of muscular action, from that of hard riding to that of still harder climbing. It is a lesson worth remembering, as in some cases it might cause much difficulty.

1. I have already said the mountain is composed of white quartz rock, and with it a little glossy clay-slate is associated. At the height of a few hundred feet above the plain, patches of conglomerate adhered in several places to the solid rock. They resembled in hardness, and in the nature of the cement, the masses which may be seen daily forming on some coasts. I do not doubt these pebbles were in a similar manner aggregated, at $\mathrm{s}$ period when the great calcareous formation was depositing beneath the surrounding sea. We may believe that the jagged and battered forms of the hard quartz yet show the effects of the waves of an open ocean.

I was, on the whole, disappointed with this ascent. Even the view was insignificant; - a plain like the sea, but without its beautiful colour and defined outline. The scene, however, was novel, and a little danger, like salt to meat, gave it a relish. That the danger was very little was certain, for my two companions made a good fire-a thing which is never done when it is suspected that Indians are near. I reached the place of our bivouac by sunset, and drinking much maté, and smoking several cigaritos, soon made up my bed for the night. The wind was very strong and cold, but I never slept more comfortably.

September 10th. - In the morning, having fairly scudded before the gale, we arrived by the middle of the day at the Sauce posta. On the road we saw great numbers of deer, and near the 
mountain a guanaco. The plain, which abuts against the Sierra, is traversed by some curious gulleys, of which one was about twenty feet wide, and at least thirty deep; we were obliged in consequence to make a considerable circuit before we could find a pass. We stayed the night at the posta, the conversation, as was generally the case, being about the Indians. The Sierra Ventana was formerly a great place of resort; and three or four years ago there was much fighting there. My guide had been present when many Indians were killed: the women escaped to the top of the ridge, and fought most desperately with great stones; many thus saving themselves.

September 11th.-Proceeded to the third posta in company with the lieutenant who commanded it. The distance is called fifteen leagues; but it is only guess-work, and is generally overstated. The road was uninteresting, over a dry grassy plain ; and on our left hand at a greater or less distance there were some low hills; a continuation of which we crossed close to the posta. Before our arrival we met a large herd of cattle and horses, guarded by fifteen soldiers; but we were told many had been lost. It is very difficult to drive animals across the plains ; for if in the night a puma, or even a fox, approaches, nothing can prevent the horses dispersing in every direction; and a storm will have the same effect. A short time since, an officer left Buenos Ayres with five hundred horses, and when he arrived at the army he had under twenty.

Soon afterwards we perceived by the cloud of dust, that a party of horsemen were coming towards us; when far distant my companions knew them to be Indians, by their long hair streaming behind their backs. The Indians generally have n fillet round their heads, but never any covering; and their black hair blowing across their swarthy faces, heightens to an uncommon degree the wildness of their appearance. They turned ont to be a party of Bernantio's friendly tribe, going to a salina for salt. The Indians eat much salt, their children sucking it like sugar. This habit is very different from that of the Spanish Gauchos, who, leading the same kind of life, eat scarcely any : according to Mungo Park, * it is people who live on vegetable 
food who have an unconquerable desire for salt. The Indians gave us good-humoured nods as they passed at full gallop, driving before them a troop of horses, and followed by a train of lanky dogs.

September 12 th and 13th.-I staid at this posta two days, waiting for a troop of soldiers, which General Rosas had the kindness to send to inform me, would shortly travel to Buenos Ayres; and he advised me to take the opportunity of the escort. In the morning we rode to some neighbouring hills to view the country, and to examine the geology. After dinner the soldiers divided themselves into two parties for a trial of skill with the bolas. Two spears were stuck in the ground thirty-five yards apart, but they were struck and entangled only once in four or five times. The balls can be thrown fifty or sixty yards, but with little certainty. This, however, does not apply to a man on horseback; for when the speed of the horse is added to the force of the arm, it is said, that they can be whirled with effect to the distance of eighty yards. As a proof of their force, I may mention, that at the Falkland Islands, when the Spaniards murdered some of their own countrymen and all the Englishmen, a young friendly Spaniard was running away, when a great tall man, by name Luciano, came at full gallop after him, shouting to him to stop, and saying that he only wanted to speak to him. Just as the Spaniard was on the point of reaching the boat, Luciano threw the balls: they struck him on the legs with such a jerk, as to throw him down and to render him for some time insensible. The man, after Luciano had had his talk, was allowed to escape. He told us that his legs were marked by great weals, where the thong had wound round, as if he had been flogged with a whip. In the middle of the day two men arrived, who brought a parcel from the next posta to be forwarded to the general: so that besides these two, our party consisted this evening of my guide and self, the lieutenant, and his four soldiers. The latter were strange beings; the first a fine young negro; the second half Indian and negro; and the two others nondescripts; namely, an old Chilian miner, the colour of mahogany, and another partly a mulatto; but two such mongrels, with such detestable expressions, I never saw before. At night, when they were sitting round the fire, and playing at cards, I retired to 
view such a Salvator Rosa scene. They were seated under a low cliff, so that I could look down upon them; around the party were lying dogs, arms, remnants of deer and ostriches; and their long spears were stuck in the turf. Further in the dark background, their horses were tied up, ready for any sudden danger. If the stillness of the desolate plain was broken by one of the dogs barking, a soldier, leaving the fire, would place his head close to the ground, and thus slowly scan the horizon. Even if the noisy teru-tero uttered its seream, there would be a pause in the conversation, and every head, for a moment, a little inclined.

What a life of misery these men appear to us to lead! They were at least ten leagues from the Sauce posta, and since the murder committed by the Indians, twenty from another. The Indians are supposed to have made their attack in the middle of the night; for very early in the morning after the murder, they were luckily seen approaching this posta. The whole party here, however, escaped, together with the troop of horses; each one taking a line for himself, and driving with him as many animals as he was able to manage.

'The little hovel, built of thistle-stalks, in which they slept, neither kept out the wind or rain; indeed in the latter case the only effect the roof had, was to condense it into larger drops. They had nothing to eat excepting what they could catch, such as ostriches, deer, armadilloes, \&c., and their only fuel was the dry stalks of a small plant, somewhat resembling an aloe. The sole luxury which these men enjoyed was smoking the little paper cigars, and sucking maté. I used to think that the carrion vultures, man's constant attendants on these dreary plains, while seated on the little neighbouring cliffs, seemed by their very patience to say, "Ah! when the Indians come we shall have a feast."

In the morning we al sallied forth to hunt, and although we had not much success, there were some animated chaces. Soon after starting the party separated, and so arranged their plans, that at a certain time of the day (in guessing which they show much skill) they should all meet from different points of the compass on a plain piece of ground, and thus drive together the wild animals. One day I went out hunting at Bahia Blanca, 
but the men there merely rode in a crescent, each being about a quarter of a mile apart from the other. A fine male ostrich being turned by the headmost riders, tried to escape on one side. The Gauchos pursued at a reckless pace, twisting their horses about with the most admirable command, and each man whirling the balls round his head. At length the foremost threw them, revolving through the air: in an instant the ostrich rolled over and over, its legs fairly lashed together by the thong.

The plains abound with three kinds of partridge, ${ }^{*}$ two of which are as large as hen pheasants. Their destroyer, a small and pretty fox, was also singularly numerous; in the course of the day we could not have seen less than forty or fifty. They were generally near their earths, but the dogs killed one. When we returned to the posta, we found two of the party returned who had been hunting by themselves. They had killed a puma, and had found an ostrich's nest with twenty-seven eggs in it. Each of these is said to equal in weight eleven hens' eggs ; so that we obtained from this one nest as much food as 297 hens' eggs would have given.

September 14th. - As the soldiers belonging to the next posta meant to return, and we should together make a party of five, and all armed, I determined not to wait for the expected troops. My host, the lieutenant, pressed me much to stop. As he had been very obliging-not only providing me with food, but lending me his private horses-I wanted to make him some remuneration. I asked my guide whether I might do so, but he told me certainly not; that the only answer I should receive, probably would be, "We have meat for the dogs in our country, and therefore do not grudge it to a Christian." It must not be supposed that the rank of lieutenant in such an army would at all prevent the acceptance of payment: it was only the high sense of hospitality, which every traveller is bound to acknowledge as nearly universal throughout these provinces. After galloping some leagues, we came to a low swampy country, which extends for nearly eighty miles northward, as far as the Sierra Tapalguen. In some parts there were fine damp plains, covered with grass, while others had a soft, black, and peaty soil. There

* Two species of Tinamus, and Eudromia elegans of A. d'Orbigny, which can only be called a partridge with regard to its habits. 
were also many extensive but shallow lakes, and large beds of reeds. The country on the whole resembled the better parts of the Cambridgeshire fens. At night we had some difficulty in finding, amidst the swamps, a dry place for our bivouac.

September 15 th. - Rose very early in the morning, and shortly after passed the posta where the Indians had murdered the five soldiers. The officer had eighteen chuzo wounds in his body. By the middle of the day, after a hard gallop, we reached the fifth posta: on account of some difficulty in procuring horses we stayed there the night. As this point was the most exposed on the whole line, twenty-one soldiers were stationed here; at sunset they returned from hunting, bringing with them seven deer, three ostriches, and many armadilloes and partridges. When riding through the country, it is a common practice to set fire to the plain; and hence at night, as on this occasion, the horizon was illuminated in several places by brilliant conflagrations. This is done partly for the sake of puzzling any stray Indians, but chiefly for improving the pasture. In grassy plains unoccupied by the larger ruminating quadrupeds, it seems necessary to remove the superfluous vegetation by fire, so as to render the new year's growth serviceable.

The rancho at this place did not boast even of a roof, but merely consisted of a ring of thistle-stalks, to break the force of the wind. It was situated on the borders of an extensive but shallow lake, swarming with wild fowl, among which the blacknecked swan was conspicuous.

'The kind of plover, which appears as if mounted on stilts, (Himantopus nigricollis) is here common in flocks of considerable size. It has been wrongfully accused of inelegance; when wading about in shaliow water, which is its favourite resort, its gait is far from awkward. These birds in a flock utter a noise, that singularly resembles the cry of a pack of small dogs in full chace: waking in the night, I have more than once been for a moment startled at the distant sound. 'The teru-tero (Vanellus cayanus) is another bird, which often disturbs the stillness of the night. In appearance and habits it resembles in many respects our peewits; its wings, however, are armed with sharp spurs, like those on the legs of the common cock. As our peewit takes its name from the sound of its voice, 
so does the teru-tero. While riding over the grassy plains, one is constantly pursued by these birds, which appear to hate mankind, and I am sure deserve to be hated for their never-ceasing, unvaried, harsh screams. To the sportsman they are most annoying, by telling every other bird and animal of his approach : to the traveller in the country, they may possibly, as Molina says, do good, by warning him of the midnight robber. During the breeding season, they attempt, like our peewits, by feigning to be wounded, to draw away from their nests dogs and other enemies. The eggs of this bird are esteemed a great delicacy.

September 16th.-To the seventh posta at the foot of the Sierra Tapalguen. The country was quite level, with a coarse herbage and a soft peaty soil. 'The hovel was here remarkably neat, the posts and rafters being made of about a dozen dry thistlestalks bound together with thongs of hide; and by the support of these Ionic-like columns, the roof and sides were thatched with reeds. We were here told a fact, which I would not have credited, if I had not had partly ocular proof of it; namely, that, during the previous night, hail as large as small apples, and extremely hard, had fallen with such violence, as to kill the greater number of the wild animals. One of the men had already found thirteen deer (Cervus campestris) lying dead, and I saw their fresh hides; another of the party, a few minutes after my arrival, brought in seven more. Now I well know, that one man without dogs could hardly have killed seven deer in a week. The men believed they had seen about fifteen dead ostriches (part of one of which we had for dinner); and they said that several were running about evidently blind in one eye. Numbers of smaller birds, as ducks, hawks, and partridges, were killed. I saw one of the latter with a black mark on its back, as if it had been struck with a paving-stone. A fence of thistlestalks round the hovel was nearly broken down, and my informer, putting his head out to see what was the matter, receiver a severe cut, and now wore a bandage. The storm was said to have been of limited extent: we certainly saw from our last night's bivouac a dense cloud and lightning in this direction. It is marvellous how such strong animals as deer could thus have been killed; but I have no doubt, from the evidence I have given, that the story is not in the least exaggerated. I am glad, 
however, to have its credibility supported by the Jesuit Drobrizhoffer, * who, speaking of a country much to the northward, says, hail fell of an enormous size and killed vast numbers of cattle: the Indians hence called the place Lalegraicavalca, meaning "the little white things." Dr. Malcolmson, also, informs me that he witnessed in 1831 in India, a hail-storm, which killed numbers of large birds and much injured the cattle. These hail-stones were flat, and one was ten inches in circumference, and another weighed two ounces. They ploughed up a gravel-walk like musket-balls, and passed through glass-windows, making round holes, but not cracking them.

Having finished our dinner of hail-stricken meat, we crossed the Sierra Tapalguen; a low range of hills, a few hundred feet in height, which commences at Cape Corrientes. The rock in this part is pure quartz; further eastward I understand it is granitic. The hills are of a remarkable form; they consist, of flat patches of table-land, surrounded by low perpendicular cliffs, like the outliers of a sedimentary deposit. The hill which I ascended was very small, not above a couple of hundred yards in diameter; but I saw others larger. One which goes by the name of the "Corral," is said to be two or three miles in diameter, and encompassed by perpendicular cliffs between thirty and forty feet high, excepting at one spot, where the entrance lies. Falconer $\dagger$ gives a curious account of the Indians driving troops of wild horses into it, and then by guarding the entrance, keeping them secure. I have never heard of any other instance of table-land in a formation of quartz, and which, in the hill I examined, had neither cleavage nor stratification. I was told that the rock of the "Corral" was white, and would strike fire.

We did not reach the posta on the Rio Tapalguen till after it was dark. At supper, from something which was said, I was suddenly struck with horror at thinking that I was eating one of the favourite dishes of the country, namely, a half-formed calf, long before its proper time of birth. It turned out to be Puma; the meat is very white, and remarkably like veal in taste. Dr. Shaw was laughed at for stating that "the flesh of the lion is in great esteem, having no small affinity with veal, both in

- History of the Abipones, vol. ii. p. 6.

$\uparrow$ Falconer's Patagonia, p. 70. 
colour, taste, and flavour." Such certainly is the case with the Puma. The Gauchos differ in their opinion, whether the Jaguar is good eating, but are unanimous in saying that cat is excellent.

September 17th.-We followed the course of the Rio Tapalguen, through a very fertile country, to the ninth posta. Tapalguen itself, or the town of Tapalguen, if it may be so called, consists of a perfectly level plain, studded over, as far as the eye can reach, with the toldos, or oven-shaped huts of the Indians. The families of the friendly Indians, who were fighting on the side of Rosas, resided here. We met and passed many young Indian women, riding by two or three together on the same horse: they, as well as many of the young men, were strikingly handsome, - their fine ruddy complexions being the picture of health. Besides the toldos, there were three ranchos; one inhabited by the Commandant, and the two others by Spaniards with small shops.

We were here able to buy some biscuit. I had now been several days without tasting any thing besides meat: I did not at all dislike this new regimen; but I felt as if it would only have agreed with me with hard exercise. I have heard that patients in England, when desired to confine themselves exclusively to an animal diet, even with the hope of life before their eyes, have hardly been able to endure it. Yet the Gaucho in the Pampas, for months together, touches nothing but beef. But they eat, I observe, a very large proportion of fat, which is of a less animalized nature; and they particularly dislike dry meat, such as that of the Agouti. Dr. Richardson, ${ }^{*}$ also, has remarked, "that when people have fed for a long time solely upon lean animal food, the desire for fat becomes so insatiable, that they can consume a large quantity of unmixed and even oily fat without nausea:" this appears to me a curious physiological fact. It is, perhaps, from their meat regimen that the Gauchos, like other carnivorous animals, can abstain long from food. I was told that at Tandeel, some troops voluntarily pursued a party of Indians for three days, without eating or drinking.

We saw in the shops many articles, such as horsecloths, belts,

- Fauna Boreali-Americana, vol. i. p. 35. 
and garters, woven by the Indian women. The patterns were very pretty, and the colours brilliant; the workmanship of the garters was so good that an English merchant at Buenos Ayres maintained they must have been manufactured in England, till he found the tassels had been fastened by split sinew.

September $18 t h$. - We had a very long ride this day. At the twelfth posta, which is seven leagues south of the Rio Salado, we came to the first estancia with cattle and white women. Afterwards we had to ride for many miles through a country flooded with water above our horses' knees. By crossing the stirrups, and riding Arab-like with our legs bent up, we contrived to keep tolerably dry. It was nearly dark when we arrived at the Salado; the stream was deep, and about forty yards wide; in summer, however, its bed becones almost dry, and the little remaining water nearly as salt as that of the sea. We slept at one of the great estancias of General Rosas. It was fortified, and of such an extent, that arriving in the dark I thought it was a town and fortress. In the morning we saw immense herds of cattle, the general here having seventy-four square leagues of land. Formerly nearly three hundred men were employed about this estate, and they defied all the attacks of the Indians.

September 19th.-Passed the Guardia del Monte. This is a nice scattered little town, with many gardens, full of peach and quince trees. The plain here looked like that around Buenos Ayres; the turf being short and bright green, with beds of clover and thistles, and with bizcacha holes. I was very much struck with the marked change in the aspect of the country after having crossed the Salado. From a coarse herbage we passed on to a carpet of fine green verdure. I at first attributed this to some change in the nature of the soil, but the inhabitants assured me that here, as well as in Banda Oriental, where there is as great a difference between the country around Monte Video and the thinly-inhabited savannahs of Colonia, the whole was to be attributed to the manuring and grazing of the cattle. Exactly the same fact has been observed in the prairies* of North America, where coarse grass, between five and six feet high,

* See Mr. Atwater's account of the Prairies, in Silliman's N. A. Journal, vol. i. p. 117. 
when grazed by cattle, changes into common pasture land. I am not botanist enough to say whether the change here is owing to the introduction of new species, to the altered growth of the same, or to a difference in their proportional numbers. Azara has also observed with astonishment this change: he is likewise much perplexed by the immediate appearance of plants not occurring in the neighbourhood, on the borders of any track that leads to a newly-constructed hovel. In another part he says, ${ }^{*}$ " ces chevaux (sauvages) ont la manie de préférer les chemins, et le bord des routes pour déposer leurs excrémens, dont on trouve des monceaux dans ces endroits." Does this not partly explain the circumstance? We thus have lines of richly-manured land serving as channels of communication across wide districts.

Near the Guardia we find the southern limit of two European plants, now become extraordinarily common. The fennel in great profusion covers the ditch-banks in the neighbourhood of Buenos Ayres, Monte Video, and other towns. But the cardoon (Cynara cardunculus) $\dagger$ has a far wider range: it occurs in these latitudes on both sides of the Cordillera, across the continent. I saw it in unfrequented spots in Chile, Entre Rios, and Banda Oriental. In the latter country alone, very many (probably several hundred) square miles are covered by one mass of these prickly plants, and are impenetrable by man or beast. Over the undulating plains, where these great beds occur, nothing else can now live. Before their introduction, however, the surface must have supported, as in other parts, a rank herbage. I doubt whether any case is on record of an invasion on so grand a scale of one plant over the aborigines. As I have already said, I nowhere saw the cardoon south of the Salado; but it is

- Azara's Voyage, vol. i. p. 373.

+ M. A. d'Orbigny (vol. i. p. 474) says that the cardoon and artichoke are both found wild. Dr. Hooker (Botanical Magazine, vol. lv. p. 2362), has described a variety of the Cynara from this part of South America under the name of inermis. He states that botanists are now generally agreed that the cardoon and the artichoke are varieties of one plant. I may add, that an intelligent farmer assured me that he had observed in a deserted garden some artichokes changing into the common cardoon. Dr. Hooker believes that Head's vivid description of the thistle of the Pampas applies to the cardoon; but this is a mistake. Captain Head referred to the plant, which I have mentioned a few lines lower down, under the title of giant thistle. Whether it is a true thistle, I do not know; but it is quite different from the cardoon; and more like a thistle properly so called. 
probable that in proportion as that country becomes inhabited, the cardoon will extend its limits. The case is different with the giant thistle (with variegated leaves) of the Pampas, for I met with it in the valley of the Sauce. According to the principles so well laid down by Mr. Lyell, few countries have undergone more remarkable changes, since the year 1535, when the first colonist of La Plata landed with seventy-two horses. The countless herds of horses, cattle, and sheep, not only have altered the whole aspect of the vegetation, but they have almost banished the guanaco, deer, and ostrich. Numberless other changes must likewise have taken place; the wild pig in some parts probably replaces the peccari ; packs of wild dogs may be heard howling on the wooded banks of the less frequented streams; and the common cat, altered into a large and fierce animal, inhabits rocky hills. As M. d'Orbigny has remarked, the increase in numbers of the carrion-vulture, since the introduction of the domestic animals, must have been infinitely great; and we have given reasons for believing that they have extended their southern range. No doubt many plants, besides the cardoon and fennel, are naturalized; thus the islands near the mouth of the Parana, are thickly clothed with peach and orange trees, springing from seeds carried there by the waters of the river.

While changing horses at the Guardia several people questioned us much about the army, - I never saw any thing like the enthusiasm for Rosas, and for the success of the "most just of all wars, because against barbarians." This expression, it must be confessed, is very natural, for till lately, neither man, woman, nor horse, was safe from the attacks of the Indians. We had a long day's ride over the same rich green plain, abounding with various flocks, and with here and there a solitary estancia, and its one ombu tree. In the evening it rained heavily: on arriving at a post-house we were told by the owner that if we had not a regular passport we must pass on, for there were so many robbers he would trust no one. When he read, however, my passport, which began with "El Naturalista Don Carlos," his respect and civility were as unbounded as his suspicions had been before. What a naturalist might be, neither he nor his countrymen, I suspect, had any idea; but probably my title lost nothing
of its value from that cause. 
September 20th. - We arrived by the middle of the day at Buenos Ayres. The outskirts of the city looked quite pretty, with the agave hedges, and groves of olive, peach, and willow trees, all just throwing out their fresh green leaves. I rode to the house of Mr. Lumb, an English merchant, to whose kindness and hospitality, during my stay in the country, I was greatly indebted.

The city of Buenos Ayres is large; of the most regular in the world. Every street is at right angles to the one it crosses, and the parallel ones being equidistant, the houses are collected into solid squares of equal dimensions, which are called quadras. On the other hand, the houses themselves are hollow squares; all the rooms opening into a neat little courtyard. They are generally only one story high, with flat roofs, which are fitted with seats, and are much frequented by the inhabitants in summer. In the centre of the town is the Plaza, where the public offices, fortress, cathedral, \&c., stand. Here also, the old viceroys, before the revolution, had their palaces. The general assemblage of buildings possesses considerable architectural beauty, although none individually can boast of any.

The great corral, where the animals are kept for slaughter to supply food to this beef-eating population, is one of the spectacles best worth seeing. The strength of the horse as compared to that of the bullock is quite astonishing: a man on horseback having thrown his lazo round the horns of a beast, can drag it any where he chooses. The animal ploughing up the ground with outstretched legs, in vain efforts to resist the force, generally dashes at full speed to one side; but the horse immediately turning to receive the shock, stands so firmly that the bullock is almost thrown down, and it is surprising that their necks are not broken. The struggle is not, however, one of fair strength; the horse's girth being matched against the bullock's extended neck. In a similar manner a man can hold the wildest horse, if caught with the lazo, just behind the ears. When the bullock has been dragged to the spot where it is to be slaughtered, the matador with great caution cuts the hamstrings. Then is given

* It is said to contain 60,000 inhabitants. Monte Video, the second town of importance on the banks of the Plata, has 15,000. 
the death bellow; a noise more expressive of fierce agony than any I know: I have often distinguished it from a long distance, and have always known that the struggle was then drawing to a close. The whole sight is horrible and revolting: the ground is almost made of bones; and the horses and riders are drenched with gore. 


\section{CHAPTER VII.}

Excursion to St. Fé-Thistle Beds-Habits of the Bizcacha-Little OwlSaline Streams-Level Plains-Mastodon-St. Fé-Change in Landscape -Geology-Tooth of extinct Horse-Relation of the Fossil and recent Quadrupeds of North and South America-Effects of a great DroughtParana-Habits of the Jaguar-Scissor-beak-Kingfisher, Parrot, and Scissor-tail-Revolution-Buenos Ayres-State of Government.

\section{BUENOS AYRES TO ST. FE'.}

September $27 t h$. - Ix the evening I set out on an excursion to St. Fé, which is situated nearly three hundred English miles from Buenos Ayres, on the banks of the Parana. The roads in the neighbourhood of the city, after the rainy weather, were extraordinarily bad. I should never have thought it possible for a bullock waggon to have crawled along: as it was, they scarcely went at the rate of a mile an hour, and a man was kept ahead, to survey the best line for making the attempt. The bullocks were terribly jaded: it is a great mistake to suppose that with improved roads, and an accelerated rate of travelling, the sufferings of the animals increase in the same proportion. We passed a train of waggons and a troop of beasts on their road to Mendoza. The distance is about 580 geographical miles, and the journey is generally performed in fifty days. These waggons are very long, narrow, and thatched with reeds; they have only two wheels, the diameter of which in some cases is as much as ten feet. Each is drawn by six bullocks, which are urged on by a goad at least twenty feet long: this is suspended from within the roof; for the wheel bullocks a smaller one is kept; and for the intermediate pair, a point projects at right angles from the middle of the long one. The whole apparatus looked like some implement of war.

September 28th.-We passed the small town of Luxan, where there is a wooden bridge over the river-a most unusual convenience in this country. We passed also Areco. The plains 
appeared level, but were not so in fact; for in various places the horizon was distant. The estancias are here wide apart; for there is little good pasture, owing to the land being covered by beds either of an acrid clover, or of the great thistle. The latter, well known from the animated description given by Sir F. Head, were at this time of the year two-thirds grown; in some parts they were as high as the horse's back, but in others they had not yet sprung up, and the ground was bare and dusty as on a turnpike-road. The clumps were of the most brilliant green, and they made a pleasing miniature-likeness of broken forest land. When the thistles are full grown, the great beds are impenetrable, except by a few tracks, as intricate as those in a labyrinth. These are only known to the robbers, who at this season inhabit them, and sally forth at night to rob and cut throats with impunity. Upon asking at a house whether robbers were numerous, I was answered, "The thistles are not up yet;"--the meaning of which reply was not at first very obvious. There is little interest in passing over these tracts, for they are inhabited by few animals or birds, excepting the bizcacha and its friend the little owl.

The bizcacha* is well known to form a prominent feature in the zoology of the Pampas. It is found as far south as the Rio Negro, in lat. $41^{\circ}$, but not beyond. It cannot, like the agouti, subsist on the gravelly and desert plains of Patagonia, but prefers a clayey or sandy soil, which produces a different and more abundant vegetation. Near Mendoza, at the foot of the Cordillera, it occurs in close neighbourhood with the allied alpine species. It is a very curious circumstance in its geographical distribution, that it has never been seen, fortunately for the inhabitants of Banda Oriental, to the eastward of the river Uruguay : yet in this province there are plains which appear admirably adapted to its habits. The Uruguay has formed an insuperable obstacle to its migration; although the broader barrier of the Parana has been passed, and the bizcacha is common in Entre Rios, the province between these two great rivers. Near Buenos Ayres these animals are exceedingly common. Their * The bizcacha (Lagostomus trichodactylus) somewhat resembles a large
rabbit, but with bigger gnawing teeth and a long tail : it has, however, only
three toes behind, like the agouti. three toes behind, like the agouti. During the last three or four years the skins of these animals have been sent to England for the sake of the fur. 
most favourite resort appears to be those parts of the plain which during one half of the year are covered with giant thistles, to the exclusion of other plants. The Gauchos affirm that it lives on roots; which, from the great strength of its gnawing teeth, and the kind of places frequented by it, seems probable. In the evening the bizcachas come out in numbers, and quietly sit at the mouths of their burrows on their haunches. At such times they are very tame, and a man on horseback passing by seems only to present an object for their grave contemplation. They run very awkwardly, and when running out of danger, from their elevated tails and short front legs, much resemble great rats. Their flesh, when cooked, is very white and good, but it is seldom used.

The bizcacha has one very singular habit; namely, dragging every hard object to the mouth of its burrow: around each group of holes many bones of cattle, stones, thistle-stalks, hard lumps of earth, dry dung, \&c., are collected into an irregular heap, which frequently amounts to as much as a wheelbarrow would contain. I was credibly informed that a gentleman, when riding on a dark night, dropped his watch; he returned in the morning, and by searching the neighbourhood of every bizcacha hole on the line of road, as he expected, he soon found it. This habit of picking up whatever may be lying on the ground any where near its habitation, must cost much trouble. For what purpose it is done, I am quite unable to form even the most remote conjecture: it cannot be for defence, because the rubbish is chiefly placed above the mouth of the burrow, which enters the ground at a very small inclination. No doubt there must exist some good reason; but the inhabitants of the country are quite ignorant of it. The only fact which I know analogous to it, is the habit of that extraordinary Australian bird, the Calodera maculata, which makes an elegant vaulted passage of twigs for playing in, and which collects near the spot, land and seashells, bones, and the feathers of birds, especially brightly coloured ones. Mr. Gould, who has described these facts, informs me, that the natives, when they lose any hard object, search the playing passages, and he has known a tobacco-pipe thus recovered.

The little owl (Athene cunicularia), which has been so often 
mentioned, on the plains of Buenos Ayres exclusively inhabits the holes of the bizcacha; but in Banda Oriental it is its own workman. During the open day, but more especially in the evening, these birds may be seen in every direction standing frequently by pairs on the hillock near their burrows. If disturbed they either enter the hole, or, uttering a shrill harsh cry, move with a remarkably undulatory flight to a short distance, and then turning round, steadily gaze at their pursuer. Occasionally in the evening they may be heard hooting. I found in the stomachs of two which $I$ opened the remains of mice, and I one day saw a small snake killed and carried away. It is said that snakes are their common prey during the daytime. I may here mention, as showing on what various kinds of food owls subsist, that a species killed among the islets of the Chonos Archipelago, had its stomach full of good-sized crabs. In India* there is a fishing genus of owls, which likewise catches crabs.

In the evening we crossed the Rio Arrecife on a simple raft made of barrels lashed together, and slept at the post-house on the other side. I this day paid horse-hire for thirty-one leagues; and although the sun was glaring hot I was but little fatigued. When Captain Head talks of riding fifty leagues a day, I do not imagine the distance is equal to 150 English miles. At all events, the thirty-one leagues was only 76 miles in a straight line, and in an open country I should think four additional miles for turnings would be a sufficient allowance.

29 th and 30th. - We continued to ride over plains of the same character. At San Nicolas I first saw the noble river of the Parana. At the foot of the cliff on which the town stands, some large vessels were at anchor. Before arriving at Rozario, we crossed the Saladillo, a stream of fine clear running water, but too saline to drink. Rozario is a large town built on a dead level plain, which forms a cliff about sixty feet high over the Parana. The river here is very broad, with many islands, which are low and wooded, as is also the opposite shore. The view would resemble that of a great lake, if it were not for the linear shaped islets, which alone give the idea of running water. The cliffs are the most picturesque part; sometimes they are absolutely perpendicular, and of a red colour; at other times in large

- Journal of Asiatic Soc., rol. v. p. 363. 
broken masses, covered with cacti and mimosa-trees. The real grandeur, however, of an immense river like this, is derived from reflecting how important a means of communication and commerce it forms between one nation and another; to what a distance it travels; and from how vast a territory it drains the great body of fresh water which flows past your feet.

For many leagues north and south of San Nicolas and Rozario, the country is really level. Scarcely anything which travellers have written about its extreme flatness, can be considered as exaggeration. Yet I could never find a spot where, by slowly turning round, objects were not seen at greater distances in some directions than in others; and this manifestly proves inequality in the plain. At sea, a person's eye being six feet above the surface of the water, his horizon is two miles and four-fifths distant. In like manner, the more level the plain, the more nearly does the horizon approach within these narrow limits; and this, in my opinion, entirely destroys that grandeur which one would have imagined that a vast level plain would have possessed.

October 1st.-We started by moonlight and arrived at the Rio Tercero by sunrise. This river is also called the Saladillo, and it deserves the name, for the water is brackish. I stayed here the greater part of the day, searching for fossil bones. Besides a perfect tooth of the Toxodon, and many scattered bones, I found two immense skeletons near each other, projecting in bold relief from the perpendicular cliff of the Parana. They were, however, so completely decayed, that I could only bring away small fragments of one of the great molar teeth; but these are sufficient to show that the remains belonged to a Mastodon, probably to the same species with that, which formerly must have inhabited the Cordillera in Upper Peru in such great numbers. The men who took me in the canoe, said they had long known of these skeletons, and had often wondered how they had got there: the necessity of a theory being felt, they came to the conclusion that, like the bizcacha, the mastodon was formerly a burrowing animal! In the evening we rode another stage, and crossed the Monge, another brackish stream, bearing the dregs of the washings of the Pampas.

October 2nd.-We passed through Corunda, which, from the luxuriance of its gardens, was one of the prettiest villages I saw. 
From this point to St. Fé the road is not very safe. The western side of the Parana northward, ceases to be inhabited; and hence the Indians sometimes come down thus far, and waylay travellers. The nature of the country also favours this, for instead of a grassy plain, there is an open woodland, composed of low prickly mimosas. We passed some houses that had been ransacked and since deserted; we saw also a spectacle, which my guides viewed with high satisfaction; it was the skeleton of an Indian with the dried skin hanging on the bones, suspended to the branch of a tree.

In the morning we arrived at St. Fé. I was surprised to observe how great a change of climate a difference of only three degrees of latitude between this place and Buenos Ayres had caused. This was evident from the dress and complexion of the men-from the increased size of the ombu-trees - the number of new cacti and other plants-and especially from the birds. In the course of an hour I remarked half-a-dozen birds, which I had never seen at Buenos Ayres. Considering that there is no natural boundary between the two places, and that the character of the country is nearly similar, the difference was much greater than I should have expected.

October $3 r d$ and 4 th. I I was confined for these two days to my bed by a headach. A good-natured old woman, who attended me, wished me to try many odd remedies. A common practice is, to bind an orange-leaf or a bit of black plaster to each temple : and a still more general plan is, to split a bean into halves, moisten them, and place one on each temple, where they will easily adhere. It is not thought proper ever to remove the beans or plaster, but to allow them to drop off; and sometimes, if a man, with patehes on his head, is asked, what is the matter? he will answer, "I had a headach the day before yesterday." Many of the remedies used by the people of the country are ludicrously strange, but too disgusting to be mentioned. One of the least nasty is to kill and cut open two puppies and bind them on each side of a broken limb. Little hairless dogs are in great request to sleep at the feet of invalids.

St. Fé is a quiet little town, and is kept clean and in good order. The governor, Lopez, was a common soldier at the time of the revolution; but has now been seventeen years in power. 
This stability of government is owing to his tyrannical habits; for tyranny seems as yet better adapted to these countries than republicanism. The governor's favourite occupation is hunting Indians: a short time since he slaughtered forty-eight, and sold the children at the rate of three or four pounds apiece.

October 5th.-We crossed the Parana to St. Fé Bajada, a town on the opposite shore. The passage took some hours, as the river here consisted of a labyrinth of small streams, separated by low wooded islands. I had a letter of introduction to an old Catalonian Spaniard, who treated me with the most uncommon hospitality. The Bajada is the capital of Entre Rios. In 1825 the town contained 6000 inhabitants, and the province 30,000 ; yet, few as the inhabitants are, no province has suffered more from bloody and desperate revolutions. They boast here of representatives, ministers, a standing army, and governors: so it is no wonder that they have their revolutions. At some future day this must be one of the richest countries of La Plata. The soil is varied and productive; and its almost insular form gives it two grand lines of communication by the rivers Parana and Uruguay.

I was delayed here five days, and employed myself in examining the geology of the surrounding country, which was very interesting. We here see at the bottom of the cliffs, beds containing sharks' teeth and sea-shells of extinct species, passing above into an indurated marl, and from that inte the red clayey earth of the Pampas, with its calcareous concretions and the bones of terrestrial quadrupeds. This vertical section clearly tells us of a large bay of pure salt-water, gradually encroached on, and at last converted into the bed of a muddy estuary, into which floating carcasses were swept. At Punta Gorda, in Banda Oriental, I found an alternation of the Pampæan estuary deposit, with a limestone containing some of the same extinct sea-shells; and this shows either a change in the former currents, or more probably an oscillation of level in the bottom of the ancient estuary. Until lately, my reasons for considering the Pampæan formation to be an estuary deposit were, its general appearance, its position at the mouth of the existing great river the Plata, and the presence of so many bones of terrestrial quadrupeds: but now Professor 
Ehrenberg has had the kindness to examine for me a little of the red earth, taken from low down in the deposit, close to the skeletons of the mastodon, and he finds in it many infusoria, partly salt-water and partly fresh-water forms, with the latter rather preponderating; and therefore, as he remarks, the water must have been brackish. M. A. d'Orbigny found on the banks of the Parana, at the height of a hundred feet, great beds of an estuary shell, now living a hundred miles lower down nearer the sea; and I found similar shells at a less height on the banks of the Uruguay: this shows that just before the Pampas was slowly elevated into dry land, the water covering it was brackish. Below Buenos Ayres there are upraised beds of sea-shells of existing species, which also proves that the period of elevation of the Pampas was within the recent period.

- In the Pampæan deposit at the Bajada I found the osseous armour of a gigantic armadillo-like animal, the inside of which, when the earth was removed, was like a great cauldron; I found also teeth of the Toxodon and Mastodon, and one tooth of a Horse, in the same stained and decayed state. This latter tooth greatly interested me,* and I took scrupulous care in ascertaining that it had been embedded contemporaneously with the other remains; for I was not then aware that amongst the fossils from Bahia Blanca there was a horse's tooth hidden in the matrix : nor was it then known with certainty that the remains of horses are common in North America. Mr. Lyell has lately brought from the United States a tooth of a horse; and it is an interesting fact, that Professor Owen could find in no species, either fossil or recent, a slight but peculiar curvature characterizing it, until he thought of comparing it with my specimen found here: he has named this American horse Equus curvidens. Certainly it is a marvellous fact in the history of the Mammalia, that in South America a native horse should have lived and disappeared, to be succeeded in after ages by the countless herds descended from the few introduced with the Spanish colonists!

The existence in South America of a fossil horse, of the mastodon, possibly of an elephant, $\uparrow$ and of a hollow-horned

* I need hardly state here that there is good evidence against any horse living in America at the time of Columbus.

† Cuvier, Ossemens Fossiles, tom. i. p. 158. 
ruminant, discovered by MM. Lund and Clausen in the caves of Brazil, are highly interesting facts with respect to the geographical distribution of animals. At the present time, if we divide America, not by the Isthmus of Panama, but by the southern part of Mexico* in lat. $20^{\circ}$, where the great table-land presents an obstacle to the migration of species, by affecting the climate, and by forming, with the exception of some valleys and of a fringe of low land on the coast, a broad barrier; we shall then have the two zoological provinces of North and South America strongly contrasted with each other. Some few species alone have passed the barrier, and may be considered as wanderers from the south, such as the puma, opossum, kinkajou, and peccari. South America is characterized by possessing many peculiar gnawers, a family of monkeys, the llama, peccari, tapir, opossums, and, especially, several genera of Edentata, the order which includes the sloths, ant-eaters, and armadillos. North America, on the other hand, is characterized (putting on one side a few wandering species) by numerous peculiar gnawers, and by four genera (the ox, sheep, goat, and antelope) of hollow-horned ruminants, of which great division South America is not known to possess a single species. Formerly, but within the period when most of the now existing shells were living, North America possessed, besides hollow-horned ruminants, the elephant, mastodon, horse, and three genera of Edentata, namely, the Megatherium, Megalonyx, and Mylodon. Within nearly this same periods (as proved by the shells at Bahia Blanca) South America possessed, as we have just seen, a mastodon, horse, hollow-horned ruminant, and the same three genera (as well as several others) of the Edentata. Hence it is evident that North and South America, in having within a late geological period these several genera in common, were much more closely related in the character of their terrestrial inhabitants than they now are.

* This is the geographical division followed by Lichtenstein, Swainson, Erichson, and Richardson. The section from Vera Cruz to Acapulco, given by Humboldt in the Polit. Essay on Kingdom of N. Spain, will show how immense a barrier the Mexican table-land forms. Dr. Richardson, in his admirable Report on the Zoology of N. America read before the Brit. Assoc. 1836 (p. 157), talking of the identification of a Mexican animal with the Synetheres prehensilis, says, "We do not know with what propriety, but if correct, it is, if not a solitary instance, at least very nearly so, of a rodent animal being common to North and South America." 
The more I reflect on this case, the more interesting it appears : I know of no other instance where we can almost mark the period and manner of the splitting up of one great region into two well-characterized zoological provinces. The geologist, who is fully impressed with the vast oscillations of level which have affected the earth's crust within late periods, will not fear to speculate on the recent elevation of the Mexican platform, or, more probably, on the recent submergence of land in the West Indian Archipelago, as the cause of the present zoological separation of North and South America. The South American character of the West Indian mammals * seems to indicate that this archipelago was formerly united to the southern continent, and that it has subsequently been an area of subsidence.

When America, and especially North America, possessed its elephants, mastodons, horse, and hollow-horned ruminants, it was much more closely related in its zoological characters to the temperate parts of Europe and Asia than it now is. As the remains of these genera are found on both sides of Behring's Straits $\nmid$ and on the plains of Siberia, we are led to look to the north-western side of North America as the former point of communication between the Old and so-called New World. And as so many species, both living and extinct, of these same genera inhabit and have inhabited the Old World, it seems most probable that the North American elephants, mastodons, horse, and hollowhorned ruminants migrated, on land since submerged near Behring's Straits, from Siberia into North America, and thence, on land since submerged in the West Indies, into South America, where for a time they mingled with the forms characteristic of that southern continent, and have since become extinct.

While travelling through the country, I received several vivid descriptions of the effects of a late great drought; and the account of this may throw some light on the cases where vast

* See Dr. Richardson's Report, p. 157; also L'Institut, 1837, p. 253. Cuvier says the kinkajou is found in the larger Antilles, but this is doubtful. M. Gervais states that the Didelphis crancrivora is found there. It is certain that the West Indies possess some mammifers peculiar to themselves. A tooth of a mastodon has been brought from Bahama: Edin. New Phil. Journ. 1826, p. 395 .

$\dagger$ See the admirable Appendix by Dr. Buckland to Beechey's Voyage; also the writings of Chamisso in Kotzebue's Voyage. 
numbers of animals of all kinds have been embedded together. The period included between the years 1827 and 1830 is called the "gran seco," or the great drought. During this time so little rain fell, that the vegetation, even to the thistles, failed; the brooks were dried up, and the whole country assumed the appearance of a dusty high road. This was especially the case in the northern part of the province of Buenos Ayres and the southern part of St. Fé. Very great numbers of birds, wild animals, cattle, and horses perished from the want of food and water. A man told me that the deer* used to come into his courtyard to the well, which he had been obliged to dig to supply his own family with water; and that the partridges had hardly strength to fly away when pursued. The lowest estimation of the loss of cattle in the province of Buenos Ayres alone, was taken at one million head. A proprietor at San Pedro had previously to these years 20,000 cattle; at the end not one remained. San Pedro is situated in the middle of the finest country ; and even now abounds again with animals ; yet, during the latter part of the "gran seco," live cattle were brought in vessels for the consumption of the inhabitants. The animals roamed from their estancias, and, wandering far southward, were mingled together in such multitudes, that a government commission was sent from Buenos Ayres to settle the disputes of the owners. Sir Woodbine Parish informed me of another and very curious source of dispute; the ground being so long dry, such quantities of dust were blown about, that in this open country the landmarks became obliterated, and people could not tell the limits of their estates.

I was informed by an eyewitness that the cattle in herds of thousands rushed into the Parana, and being exhausted by hunger they were unable to crawl up the muddy banks, and thus were

* In Capt. Owen's Surveying Voyage (vol. ii. p. 274) there is a curious account of the effects of a drought on the elephants, at Benguela (west coast of Africa). "A number of these animals had some time since entered the town, in a body, to possess themselves of the wells, not being able to procure any water in the country. The inhabitants mustered, when a desperate conflict ensued, which terminated in the uItimate discomfiture of the invaders, but not until they had killed one man, and wounded several others." The town is said to have a population of nearly three thousand! Dr. Malcolmson informs me, that during a great drought in India the wild animals entered the tents of some troops at Ellore, and that a hare drank out of a vessel held by the adjutant of the regiment. 
drowned. The arm of the river which runs by San Pedro was so full of putrid carcasses, that the master of a vessel told me that the smell rendered it quite impassable. Without doubt several hundred thousand animals thus perished in the river: their bodies when putrid were seen floating down the stream; and many in all probability were deposited in the estuary of the Plata. All the small rivers became highly saline, and this caused the death of vast numbers in particular spots ; for when an animal drinks of such water it does not recover. Azara describes* the fury of the wild horses on a similar occasion, rushing into the marshes, those which arrived first being overwhelmed and crushed by those which followed. He adds that more than once he has seen the carcasses of upwards of a thousand wild horses thus destroyed. I noticed that the smaller streams in the Pampas were paved with a breccia of bones, but this probably is the effect of a gradual increase, rather than of the destruction at any one period. Subsequently to the drought of 1827 to '32, a very rainy season followed, which caused great floods. Hence it is almost certain that some thousands of the skeletons were buried by the deposits of the very next year. What would be the opinion of a geologist, viewing such an enormous collection of bones, of all kinds of animals and of all ages, thus embedded in one thick earthy mass? Would he not attribute it to a flood having swept over the surface of the land, rather than to the common order of things? $\dagger$

October 12th. - I had intended to push my excursion further, but not being quite well, I was compelled to return by a balandra, or one-masted vessel of about a hundred tons' burden, which was bound to Buenos Ayres. As the weather was not fair, we moored early in the day to a branch of a tree on one of the islands. The Parana is full of islands, which undergo a constant round of decay and renovation. In the memory of the master several large ones had disappeared, and others again had been formed and protected by vegetation. They are composed of muddy sand, without even the smallest pebble, and were then

* Travels, vol, i. p. 374.

$\uparrow$ These droughts to a certain degree seem to be almost periodical; I was told the dates of several others, and the intervals were about fifteen years. 
about four feet above the level of the river; but during the periodical floods they are inundated. They all present one character; numerous willows and a few other trees are bound together by a great variety of creeping plants, thus forming a thick jungle. These thickets afford a retreat for capybaras and jaguars. The fear of the latter animal quite destroyed all pleasure in scrambling through the woods. This evening I had not proceeded a hundred yards, before finding indubitable signs of the recent presence of the tiger, I was obliged to come back. On every island there were tracks; and as on the former excursion "el rastro de los Indios" had been the subject of conversation, so in this was "el rastro del tigre."

The wooded banks of the great rivers appear to be the favourite haunts of the jaguar; but south of the Plata, I was told that they frequented the reeds bordering lakes : wherever they are, they seem to require water. Their common prey is the capybara, so that it is generally said, where capybaras are numerous there is little danger from the jaguar. Falconer states that near the southern side of the mouth of the Plata there are many jaguars, and that they chiefly live on fish; this account I have heard repeated. On the Parana they have killed many wood-cutters, and have even entered vessels at night. There is a man now living in the Bajada, who, coming up from below when it was dark, was seized on the deck; he escaped, however, with the loss of the use of one arm. When the floods drive these animals from the islands, they are most dangerous. I was told that a few years since a very large one found its way into a church at St. Fé: two padres entering one after the other were killed, and a third, who came to see what was the matter, escaped with difficulty. The beast was destroyed by being shot from a corner of the building which was unroofed. They commit also at these times great ravages among cattle and horses. It is said that they kill their prey by breaking their necks. If driven from the carcass, they seldom return to it. The Gauchos say that the jaguar, when wandering about at night, is much tormented by the foxes yelping as they follow him. This is a curious coincidence with the fact which is generally affirmed of the jackals accompanying, in a similarly officious manner, the East Indian tiger. The jaguar is a noisy animal, roaring much by night, and especially before bad weather. 
One day, when hunting on the banks of the Uruguay, I was shown certain trees, to which these animals constantly recur for the purpose, as it is said, of sharpening their claws. I saw three well-known trees; in front, the bark was worn smooth, as if by the breast of the animal, and on each side there were deep scratches, or rather grooves, extending in an oblique line, nearly a yard in length. The scars were of different ages. A common method of ascertaining whether a jaguar is in the neighbourhood is to examine these trees. I imagine this habit of the jaguar is exactly similar to one which may any day be seen in the common cat, as with outstretched legs and exserted claws it scrapes the leg of a chair; and I have heard of young fruit-trees in an orchard in England having been thus much injured. Some such habit must also be common to the puma, for on the bare hard soil of Patagonia I have frequently seen scores so deep that no other animal could have made them. The object of this practice is, I believe, to tear off the ragged points of their claws, and not, as the Gauchos think, to sharpen them. The jaguar is killed, without much difficulty, by the aid of dogs baying and driving him up a tree, where he is despatched with bullets.

Owing to bad weather we remained two days at our moorings. Our only amusement was catching fish for our dinner: there were several kinds, and all good eating. A fish called the "armado" (a Silurus) is remarkable from a harsh grating noise which it makes when caught by hook and line, and which can be distinctly heard when the fish is beneath the water. This same fish has the power of firmly catching hold of any object, such as the blade of an oar or the fishing-line, with the strong spine both of its pectoral and dorsal fin. In the evening the weather was quite tropical, the thermometer standing at $79^{\circ}$. Numbers of fireflies were hovering about, and the musquitoes were very troublesome. I exposed my hand for five minutes, and it was soon black with them; I do not suppose there could have been less than fifty, all busy sucking.

October 15th. - We got under way and passed Punta Gorda, where there is a colony of tame Indians from the province of Missiones. We sailed rapidly down the current, but before sunset, from a silly fear of bad weather, we brought-to in a narrow arm of the river. I took the boat and rowed some distance 
up this creek. It was very narrow, winding, and deep; on each side a wall thirty or forty feet high, formed by trees intwined with creepers, gave to the canal a singularly gloomy appearance. I here saw a very extraordinary bird, called the Scissor-beak (Rhynchops nigra). It has short legs, web feet, extremely longpointed wings, and is of about the size of a tern. The beak is

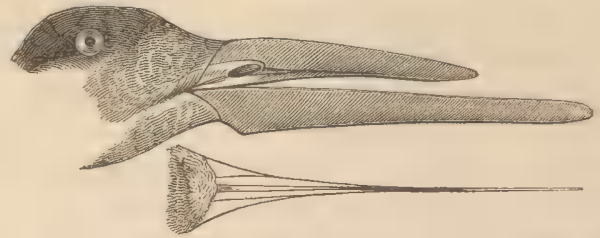

flattened laterally, that is, in a plane at right angles to that of a spoonbill or duck. It is as flat and elastic as an ivory papercutter, and the lower mandible, differently from every other bird, is an inch and a half longer than the upper. In a lake near Maldonado, from which the water had been nearly drained, and which, in consequence, swarmed with small fry, I saw several of these birds, generally in small flocks, flying rapidly backwards and forwards close to the surface of the lake. They kept their bills wide open, and the lower mandible half buried in the water. Thus skimming the surface, they ploughed it in their course: the water was quite smooth, and it formed a most curious spectacle to behold a flock, each bird leaving its narrow wake on the mirror-like surface. In their flight they frequently twist about with extreme quickness, and dexterously manage with their projecting lower mandible to plough up small fish, which are secured by the upper and shorter half of their scissor-like bills. This fact I repeatedly saw, as, like swallows, they continued to fly backwards and forwards close before me. Occasionally when leaving the surface of the water their flight was wild, irregular, and rapid; they then uttered loud harsh cries. When these birds are fishing, the advantage of the long primary feathers of their wings, in keeping them dry, is very evident. When thus employed, their forms resemble the symbol by which many artists represent marine birds. Their tails are much used in steering their irregular course. 
These birds are common far inland along the course of the Rio Parana; it is said that they remain here during the whole year, and breed in the marshes. During the day they rest in flocks on the grassy plains, at some distance from the water. Being at anchor, as I have said, in one of the deep creeks between the islands of the Parana, as the evening drew to a close, one of these scissor-beaks suddenly appeared. The water was quite still, and many little fish were rising. The bird continued for a long time to skim the surface, flying in its wild and irregular manner up and down the narrow canal, now dark with the growing night and the shadows of the overhanging trees. At Monte Video, I observed that some large flocks during the day remained on the mud-banks at the head of the harbour, in the same manner as on the grassy plains near the Parana; and every evening they took flight seaward. From these facts I suspect that the Rhynchops generally fishes by night, at which time many of the lower animals come most abundantly to the surface. M. Lesson states that he has seen these birds opening the shells of the mactræ buried in the sand-banks on the coast of Chile: from their weak bills, with the lower mandible so much projecting, their short legs and long wings, it is very improbable that this can be a general habit.

In our course down the Parana, I observed only three other birds, whose habits are worth mentioning. One is a small kingfisher (Ceryle Americana); it has a longer tail than the European species, and hence does not sit in so stiff and upright a position. Its flight also, instead of being direct and rapid, like the course of an arrow, is weak and undulatory, as among the soft-billed birds. It utters a low note, like the clicking together of two small stones. A small green parrot (Conurus murinus), with a grey breast, appears to prefer the tall trees on the islands to any other situation for its building-place. A number of nests are placed so close together as to form one great mass of sticks. These parrots always live in flocks, and commit great ravages on the corn-fields. I was told that near Colonia 2500 were killed in the course of one year. A bird with a forked tail, terminated by two long feathers (Tyrannus savana), and named by the Spaniards scissor-tail, is very common near Buenos Ayres: it commonly sits on a branch of the ombu tree, near a house, and 
thence takes a short flight in pursuit of insects, and returns to the same spot. When on the wing it presents in its manner of flight and general appearance a caricature-likeness of the common swallow. It has the power of turning very shortly in the air, and in so doing opens and shuts its tail, sometimes in a horizontal or lateral and sometimes in a vertical direction, just like a pair of scissors.

October 16th.-Some leagues below Rozario, the western shore of the Parana is bounded by perpendicular cliffs, which extend in a long line to below San Nicolas; hence it more resembles a sea-coast than that of a fresh-water river. It is a great drawback to the scenery of the Parana, that, from the soft nature of its banks, the water is very muddy. The Uruguay, flowing through a granitic country, is much clearer; and where the two channels unite at the head of the Plata, the waters may for a long distance be distinguished by their black and red colours. In the evening, the wind being not quite fair, as usual we immediately moored, and the next day, as it blew rather freshly, though with a favouring current, the master was much too indolent to think of starting. At Bajada, he was deseribed to me as "hombre muy aflicto"- -a man always miserable to get on; but certainly he bore all delays with admirable resignation. $\mathrm{He}$ was an old Spaniard, and had been many years in this country. He professed a great liking to the English, but stoutly maintained that the battle of Trafalgar was merely won by the Spanish captains having been all bought over; and that the only really gallant action on either side was performed by the Spanish admiral. It struck me as rather characteristic, that this man should prefer his countrymen being thought the worst of traitors, rather than unskilful or cowardly.

18th and 19th.-We continued slowly to sail down the noble stream: the current helped us but little. We met, during our descent, very few vessels. One of the best gifts of nature, in so grand a channel of communication, seems here wilfully thrown away - a river in which ships might navigate from a temperate country, as surprisingly abundant in certain productions as destitute of others, to another possessing a tropical climate, and a soil which, according to the best of judges, M. Bonpland, is perhaps unequalled in fertility in any part of the world. How different 
would have been the aspect of this river if English colonists had by good fortune first sailed up the Plata! What noble towns would now have occupied its shores! Till the death of Francia, the Dictator of Paraguay, these two countries must remain distinct, as if placed on opposite sides of the globe. And when the old bloody-minded tyrant is gone to his long account, Paraguay will be torn by revolutions, violent in proportion to the previous unnatural calm. That country will have to learn, like every other South American state, that a republic cannot succeed till it contains a certain body of men imbued with the principles of justice and honour.

October 20th.-Being arrived at the mouth of the Parana, and as I was very anxious to reach Buenos Ayres, I went on shore at Las Conchas, with the intention of riding there. Upon landing, I found to my great surprise that I was to a certain degree a prisoner. A violent revolution having broken out, all the ports were laid under an embargo. I could not return to my vessel, and as for going by land to the city, it was out of the question. After a long conversation with the commandant, I obtained permission to go the next day to General Rolor, who commanded a division of the rebels on this side the capital. In the morning I rode to the encampment. The general, officers, and soldiers, all appeared, and I believe really were, great villains. The general, the very evening before he left the city, voluntarily went to the Grovernor, and with his hand to his heart, pledged his word of honour that he at least would remain faithful to the last. The general told me that the city was in a state of close blockarle, and that all he could do was to give me a passport to the commanderin-chief of the rebels at Quilmes. We had therefore to take a great sweep round the city, and it was with much difficulty that we procured horses. My reception at the encampment was quite civil, but I was told it was impossible that I could be allowed to enter the city. I was very anxious about this, as I anticipated the Beagle's departure from the Rio Plata earlier than it took place. Having mentioned, however, General Rosas's obliging kindness to me when at the Colorado, magic itself could not have altered circumstances quicker than did this conversation. I was instantly told that though they could not give me a passport, if I chose to leave my guide and horses, I might pass their sen- 
tinels. I was too glad to accept of this, and an officer was sent with me to give directions that I should not be stopped at the bridge. The road for the space of a league was quite deserted. I met one party of soldiers, who were satisfied by gravely looking at an old passport: and at length I was not a little pleased to find myself within the city.

This revolution was supported by scarcely any pretext of grievances: but in a state which, in the course of nine months (from February to October, 1820), underwent fifteen changes in its government-each governor, according to the constitution, being elected for three years-it would be very unreasonable to ask for pretexts. In this case, a party of men-who, being attached to Rosas, were disgusted with the governor Balcarce-to the number of seventy left the city, and with the cry of Rosas the whole country took arms. The city was then blockaded, no provisions, cattle or horses, were allowed to enter; besides this, there was only a little skirmishing, and a few men daily killed. The outside party well knew that by stopping the supply of meat they would certainly be victorious. General Rosas could not have known of this rising; but it appears to be quite consonant with the plans of his party. A year ago he was elected governor, but he refused it, unless the Sala would also confer on him extraordinary powers. This was refused, and since then his party have shown that no other governor can keep his place. The warfare on both sides was avowedly protracted till it was possible to hear from Rosas. A note arrived a few days after I left Buenos Ayres, which stated that the General disapproved of peace having been broken, but that he thought the outside party had justice on their side. On the bare reception of this, the Governor, ministers, and part of the military, to the number of some hundreds, fled from the city. The rebels entered, elected a new governor, and were paid for their services to the number of 5500 men. From these proceedings, it was clear that Rosas ultimately would become the dictator: to the term king, the people in this, as in other republics, have a particular dislike. Since leaving South America, we have heard that Rosas has been elected, with powers and for a time altogether opposed to the constitutional principles of the republic. 


\section{CHAPTER VIII.}

Excursion to Colonia del Sacramiento - Value of an Estancia - Cattle, how counted-Singular Breed of Oxen-Perforated Pebbles-Shepherd Dogs - Horses Broken-in, Gauchos Riding - Character of Inhabitants-Rio Plata-Flocks of Butterflies - Aëronaut Spiders-Phosphorescence of the Sea-Port Desire-Guanaco-Port St. Julian-Geology of Patagonia-Fossil gigantic Animal-Types of Organization constant -Change in the Zoology of America-Causes of Extinetion.

\section{BANDA ORIENTAL AND PATAGONIA.}

Havivg been delayed for nearly a fortnight in the city, I was glad to escape on board a packet bound for Monte Video. A town in a state of blockade must always be a disagreeable place of residence; in this case moreover there were constant apprehensions from robbers within. The sentinels were the worst of all; for, from their office and from having arms in their hands, they robbed with a degree of authority which other men could not imitate.

Our passage was a very long and tedious one. The Plata looks like a noble estuary on the map; but is in truth a poor affair. A wide expanse of muddy water has neither grandeur nor beauty. At one time of the day, the two shores, both of which are extremely low, could just be distinguished from the deck. On arriving at Monte Video I found that the Beagle would not sail for some time, so I prepared for a short excursion in this part of Banda Oriental. Everything which I have said about the country near Maldonado is applicable to M. Video ; but the land, with the one exception of the Green Mount, 450 feet high, from which it takes its name, is far more level. Very little of the undulating grassy plain is enclosed; but near the town there are a few hedgebanks, covered with agaves, cacti, and fennel.

November 14th.-We left Monte Video in the afternoon. I intended to proceed to Colonia del Sacramiento, situated on the northern bank of the Plata and opposite to Buenos Ayres, and thence, following up the Uruguay, to the village of Mercedes on 
the Rio Negro (one of the many rivers of this name in South America), and from this point to return direct to Monte Video. We slept at the house of my guide at Canelones. In the morning we rose early, in the hopes of being able to ride a good distance; but it was a vain attempt, for all the rivers were flooded. We passed in boats the streams of Canelones, St. Lucia, and San José, and thus lost much time. On a former excursion I crossed the Lucia near its mouth, and I was surprised to observe how easily our horses, although not used to swim, passed over a width of at least six hundred yards. On mentioning this at Monte Video, I was told that a vessel containing some mountebanks and their horses, being wrecked in the Plata, one horse swam seven miles to the shore. In the course of the day I was amused by the dexterity with which a Gancho forced a restive horse to swim a river. He stripped off his clothes, and jumping on its back, rode into the water till it was out of its depth; then slipping off over the crupper, he caught hold of the tail, and as often as the horse turned round, the man frightened it back by splashing water in its face. As soon as the horse touched the bottom on the other side, the man pulled himself on, and was firmly seated, bridle in hand, before the horse gained the bank. A naked man on a naked horse is a fine spectacle; I had no idea how well the two animals suited each other. The tail of a horse is a very useful appendage; I have passed a river in a boat with four people in it, which was ferried across in the same way as the Gaucho. If a man and horse have to cruss a broad river, the best plan is for the man to catch hold of the pommel or mane, and help himself with the other arm.

We slept and stayed the following day at the post of Cufre. In the evening the postman or letter-carrier arrived. He was a day after his time, owing to the Rio Rozario being flooded. It would not, however, be of much consequence; for, although he had passed through some of the principal towns in Banda Oriental, his luggage consisted of two letters! The view from the house was pleasing; an undulating green surface, with distant glimpses of the Plata. I find that I look at this province with very different eyes from what I did upon my first arrival. I recollect I then thought it singularly level; but now, after galloping over the Pampas, my only surprise is, what could have 
induced me ever to have called it level. The country is a series of undulations, in themselves perhaps not absolutely great, but, as compared to the plains of St. Fé, real mountains. From these inequalities there is an abundance of small rivulets, and the turf is green and luxuriant.

November 17th. - We crossed the Rozario, which was deep and rapid, and passing the village of Colla, arrived at mid-day at Colonia del Sacramiento. The distance is twenty leagues, through a country covered with fine grass, but poorly stocked with cattle or inhabitants. I was invited to sleep at Colonia, and to accompany on the following day a gentleman to his estancia, where there were some limestone rocks. The town is built on a stony promontory something in the same manner as at Monte Video. It is strongly fortified, but both fortifications and town suffered much in the Brazilian war. It is very ancient; and the irregularity of the streets, and the surrounding groves of old orange and peach trees, gave it a pretty appearance. The church is a curious ruin; it was used as a powdermagazine, and was struck by lightning in one of the ten thousand thunder-storms of the Rio Plata. Two-thirds of the building were blown away to the very foundation; and the rest stands a shattered and curious monument of the united powers of lightning and gunpowder. In the evening I wandered about the half-demolished walls of the town. It was the chief seat of the Brazilian war;-a war most injurious to this country, not so much in its immediate effects, as in being the origin of a multitude of generals and all other grades of officers. More generals are numbered (but not paid) in the United Provinces of $\mathrm{La}$ Plata than in the United Kingdom of Great Britain. These gentlemen have learned to like power, and do not object to a little skirmishing. Hence there are many always on the watch to create disturbance and to overturn a government which as yet has never rested on any stable foundation. I noticed, however, both here and in other places, a very general interest in the ensuing election for the President; and this appears a good sign for the prosperity of this little country. The inhabitants do not require much education in their representatives; I heard some men discussing the merits of those for Colonia; and it was said that, "although they were not men of business, they could 
all sign their names :" with this they seemed to think every reasonable man ought to be satisfied.

18th.- -Rode with my host to his estancia, at the Arroyo de San Juan. In the evening we took a ride round the estate : it contained two square leagues and a half, and was situated in what is called a rincon; that is, one side was fronted by the Plata, and the two others guarded by impassable brooks. There was an excellent port for little vessels, and an abundance of small wood, which is valuable as supplying fuel to Buenos Ayres. I was curious to know the value of so complete an estancia. Of cattle there were 3000 , and it would well support three or four times that number; of mares 800 , together with 150 broken-in horses, and 600 sheep. There was plenty of water and limestone, a rough house, excellent corrals, and a peach orchard. For all this he had been offered $2000 l$, and he only wanted $500 l$. additional, and probably would sell it for less. 'The chief trouble with an estancia is driving the cattle twice a week to a central spot, in order to make them tame, and to count them. This latter operation would be thought difficult, where there are ten or fifteen thousand head together. It is managed on the principle that the cattle invariably divide themselves into little troops of from forty to one hundred. Each troop is recognised by a few peculiarly marked animals, and its number is known: so that, one being lost out of ten thousand, it is perceived by its absence from one of the tropillas. During a stormy night the cattle all mingle together; but the next morning the tropillas separate as before; so that each animal must know its fellow out of ten thousand others.

On two occasions I met with in this province some oxen of a very curious breed, called nãta or niata. They appear externally to hold nearly the same relation to other cattle, which bull or pug dogs do to other dogs. Their forehead is very short and broad, with the nasal end turned up, and the upper lip much drawn back; their lower jaws project beyond the upper, and have a corresponding upward curve; hence their teeth are always exposed. 'Their nostrils are seated high up and are very open; their eyes project outwards. When walking they carry their heads low, on a short neck; and their hinder legs are rather longer compared with the front legs than is usual. Their bare 
teeth, their short heads, and upturned nostrils give them the most ludicrous self-confident air of defiance imaginable.

Since my return, I have procured a skeleton head, through the kindness of my friend Captain Sulivan, R.N., which is now deposited in the College of Surgeons.* Don F. Muniz, of Luxan, has kindly collected for me all the information which he could respecting this breed. From his account it seems that about eighty or ninety years ago, they were rare and kept as curiosities at Buenos Ayres. The breed is universally believed to have originated amongst the Indians southward of the Plata; and that it was with them the commonest kind. Even to this day, those reared in the provinces near the Plata show their less civilized origin, in being fiercer than common cattle, and in the cow easily deserting her first calf, if visited too often or molested. It is a singular fact that an almost similar structure to the abnormal $\uparrow$ one of the niata breed, characterizes, as I am informed by Dr. Falconer, that great extinct ruminant of India, the Sivatherium. The breed is very true; and a niata bull and cow invariably produce niata calves. A niata bull with a common cow, or the reverse cross, produces offspring having an intermediate character, but with the niata characters strongly displayed: according to Señor Muniz, there is the clearest evidence, contrary to the common belief of agriculturists in analogous cases, that the niata cow when crossed with a common bull transmits her peculiarities more strongly than the niata bull when crossed with a common cow. When the pasture is tolerably long, the niata cattle feed with the tongue and palate as well as conmon cattle; but during the great droughts, when so many animals perish, the niata breed is under a great disadvantage, and would be exterminated if not attended to; for the common cattle, like horses, are able just to keep alive, by browsing with their lips on twigs of trees and reeds; this the niatas cannot so well do, as their lips do not join, and hence they are found to perish before the common cattle. This strikes me as a good illustration of how little we are able to judge from the ordinary habits of life,

* Mr. Waterhouse has drawn up a detailed description of this head, which I hope he will publish in some Journal.

† A nearly similar abuormal, but I do not know whether hereditary, structure has been observed in the carp, and likewise in the crocodile of the Ganges: Histoire des Anomalies, par M. Isid. Geoffroy St. Hilaire, tom. i. p. 244 . 
on what circumstances, occurring only at long intervals, the rarity or extinction of a species may be determined.

November 19th. - Passing the valley of Las Vacas, we slept at a house of a North American, who worked a lime-kiln on the Arroyo de las Vivoras. In the moruing we rode to a projecting headland on the banks of the river, called Punta Gorda. On the way we tried to find a jaguar. There were plenty of fresh tracks, and we visited the trees, on which they are said to sharpen their claws; but we did not succeed in disturbing one. From this point the Rio Uruguay presented to our view a noble volume of water. From the clearness and rapidity of the stream, its appearance was far superior to that of its neighbour the $\mathrm{Pa}$ rana. On the opposite coast, several branches from the latter river entered the Uruguay. As the sun was shining, the two colours of the waters could be seen quite distinct.

In the evening we proceeded on our road towards Mercedes on the Rio Negro. At night we asked permission to sleep at an estancia at which we happened to arrive. It was a very large estate, being ten leagues square, and the owner is one of the greatest landowners in the country. His nephew had charge of it, and with him there was a captain in the army, who the other day ran away from Buenos Ayres. Considering their station, their conversation was rather amusing. They expressed, as was usual, unbounded astonishment at the globe being round, and could scarcely credit that a hole would, if deep enough, come out on the other side. They had, however, heard of a country where there were six months light and six of darkness, and where the inhabitants were very tall and thin! They were curious about the price and condition of horses and cattle in England. Upon finding out we did not catch our animals with the lazo, they cried out, "Ah, then, you use nothing but the bolas :" the idea of an enclosed country was quite new to them. The captain at last said, he had one question to ask me, which he should be very much obliged if I would answer with all truth. I trembled to think how deeply scientific it would be: it was, "Whether the ladies of Buenos Ayres were not the handsomest in the world." I replied, like a renegade, "Charmingly so." He added, "I have one other question: Do ladies in any other part of the world wear such large combs?" I solemnly assured 
him that they did not. They were absolutely delighted. The captain exclaimed, "Look there! a man who has seen half the world says it is the case; we always thought so, but now we know it." My excellent judgment in combs and beauty procured me a most hospitable reception; the captain forced me to take his bed, and he would sleep on his recado.

$21 s t$. - Started at sunrise, and rode slowly during the whole day. The geological nature of this part of the province was different from the rest, and closely resembled that of the Pampas. In consequence, there were immense beds of the thistle, as well as of the cardoon: the whole country, indeed, may be called one great bed of these plants. The two sorts grow separate, each plant in company with its own kind. The cardoon is as high as a horse's back, but the Pampas thistle is often higher than the crown of the rider's head. To leave the road for a yard is out of the question; and the road itself is partly, and in some cases entirely, closed. Pasture, of course there is none; if cattle or horses once enter the bed, they are for the time completely lost. Hence it is very hazardous to attempt to drive cattle at this season of the year; for when jaded enough to face the thistles, they rush among them, and are seen no more. In these districts there are very few estancias, and these few are situated in the neighbourhood of damp valleys, where fortunately neither of these overwhelming plants can exist. As night came on before we arrived at our journey's end, we slept at a miserable little hovel inhabited by the poorest people. The extreme though rather formal courtesy of our host and hostess, considering their grade of life, was quite delightful.

November 22nd.-Arrived at an estancia on the Berquelo belonging to a very hospitable Englishman, to whom I had a letter of introduction from my friend Mr. Lumb. I stayed here three days. One morning I rode with my host to the Sierra del Pedro Flaco, about twenty miles up the Rio Negro. Nearly the whole country was covered with good though coarse grass, which was as high as a horse's belly; yet there were square leagues without a single head of cattle. The province of Banda Oriental, if well stocked, would support an astonishing number of animals; at present the annual export of hides from Monte Video amounts to three hundred thousand; and the home consumption, from 
waste, is very considerable. An estanciero told me that he often had to send large herds of cattle a long journey to a salting establishment, and that the tired beasts were frequently obliged to be killed and skinned; but that he could never persuade the Gauchos to eat of them, and every evening a fresh beast was slaughtered for their suppers! The view of the Rio Negro from the Sierra was more picturesque than any other which $I$ saw in this province. The river, broad, deep and rapid, wound at the foot of a rocky precipitous cliff: a belt of wood followed its course, and the horizon terminated in the distant undulations of the turf-plain.

When in this neighbourhood, I several times heard of the Sierra de las Cuentas : a hill distant many miles to the northward. The name signifies hill of beads. I was assured that vast numbers of little round stones, of various colours, each with a small cylindrical hole, are found there. Formerly the Indians used to collect them, for the purpose of making necklaces and bracelets-a taste, I may observe, which is common to all savage nations, as well as to the most polished. I did not know what to understand from this story, but upon mentioning it at the Cape of Good Hope to Dr. Andrew Smith, he told me that he recollected finding on the south-eastern coast of Africa, about one hundred miles to the eastward of St. John's river, some quartz crystals with their edges blunted from attrition, and mixed with gravel on the sea-beach. Each crystal was about five lines in diameter, and from an inch to an inch and a half in length. Many of them had a small canal extending from one extremity to the other, perfectly cylindrical, and of a size that readily admitted a coarse thread or a piece of fine catgut. Their colour was red or dull white. The natives were acquainted with this structure in crystals. I have mentioned these circumstances because, although no crystallized body is at present known to assume this form, it may lead some future traveller to investigate the real nature of such stones.

While staying at this estancia, I was amused with what I saw and heard of the shepherd-dogs of the country. ${ }^{*}$ When riding,

* M. A. d'Orbigny has given nearly = similar account of these dogs, tom.i. p. 175. 
it is a common thing to meet a large flock of sheep guarded by one or two dogs, at the distance of some miles from any house or man. I often wondered how so firm a friendship had been established. The method of education consists in separating the puppy, while very young, from the bitch, and in accustoming it to its future companions. An ewe is held three or four times a day for the little thing to suck, and a nest of wool is made for it in the sheep-pen; at no time is it allowed to associate with other dogs, or with the children of the family. The puppy is, moreover, generally castrated; so that, when grown up, it can scarcely have any feelings in common with the rest of its kind. From this education it has no wish to leave the flock, and just as another dog will defend its master, man, so will these the sheep. It is amusing to observe, when approaching a flock, how the dog immediately advances barking, and the sheep all close in his rear, as if round the oldest ram. These dogs are also easily taught to bring home the flock, at a certain hour in the evening. Their most troublesome fault, when young, is their desire of playing with the sheep; for in their sport they sometimes gallop their poor subjects most unmercifully.

The shepherd-dog comes to the house every day for some meat, and as soon as it is given him, he skulks away as if ashamed of himself. On these occasions the house-dogs are very tyrannical, and the least of them will attack and pursue the stranger. 'The minute, however, the latter has reached the flock, he turns round and begins to bark, and then all the housedogs take very quickly to their heels. In a similar manner a whole pack of the hungry wild dogs will scarcely ever (and I was told by some never) venture to attack a flock guarded by even one of these faithful shepherds. The whole account appears to me a curious instance of the pliability of the affections in the $d o g$; and yet, whether wild or however educated, he has a feeling of respect or fear for those that are fulfilling their instinct of association. For we can understand on no principle the wild dogs being driven away by the single one with its flock, except that they consider, from some confused notion, that the one thus associated gains power, as if in company with its own kind. F. Cuvier has observed, that all animals that readily enter into domestication, consider man as a member of their 
own society, and thus fulfil their instinct of association. In the above case the shepherd-dog ranks the sheep as its fellowbrethren, and thus gains confidence; and the wild dogs, though knowing that the individual sheep are not dogs, but are good to eat, yet partly consent to this view when seeing them in a flock with a shepherd-dog at their head.

One evening a "domidor" (a subduer of horses) came for the purpose of breaking-in some colts. I will describe the preparatory steps, for I believe they have not been mentioned by other travellers. A troop of wild young horses is driven into the corral, or large enclosure of stakes, and the door is shut. We will suppose that one man alone has to catch and mount a horse, which as yet had never felt bridle or saddle. I conceive, except by a Gaucho, such a feat would be utterly impracticable. The Gaucho picks out a full-grown colt; and as the beast rushes round the circus, he throws his lazo so as to catch both the front legs. Instantly the horse rolls over with a heavy shock, and whilst struggling on the ground, the Gaucho, holding the lazo tight, makes a circle, so as to eatch one of the hind legs, just beneath the fetlock, and draws it close to the two front legs: he then hitches the lazo, so that the three are bound together. Then sitting on the horse's neck, he fixes a strong bridle, without a bit, to the lower jaw : this he does by passing a narrow thong through the eye-holes at the end of the reins, and several times round both jaw and tongue. The two front legs are now tied closely together with a strong leathern thong, fastened by a slip-knot. The lazo, which bound the three together, being then loosed, the horse rises with difficulty. The Gaucho now holding fast the bridle fixed to the lower jaw, leads the horse outside the corral. If a second man is present (otherwise the trouble is much greater) he holds the animal's head, whilst the first puts on the horsecloths and saddle, and girths the whole together. During this operation, the horse, from dread and astonishment at thus being bound round the waist, throws himself over and over again on the ground, and, till beaten, is unwilling to rise. At last, when the saddling is finished, the poor animal can hardly breathe from fear, and is white with foam and sweat. The man now prepares to mount by pressing heavily on the stirrup, so that the horse may not lose its balance; and at the 
moment that he throws his leg over the animal's back, he pulls the slip-knot binding the front legs, and the beast is free. Some "domidors" pull the knot while the animal is lying on the ground, and, standing over the saddle, allow him to rise beneath them. The horse, wild with dread, gives a few most violent bounds, and then starts off at full gallop: when quite exhausted, the man, by patience, brings him back to the corral, where, reeking hot and scarcely alive, the poor beast is let free. Those animals which will not gallop away, but obstinately throw themselves on the ground, are by far the most troublesome. This process is tremendously severe, but in two or three trials the horse is tamed. It is not, however, for some weeks that the animal is ridden with the iron bit and solid ring, for it must learn to associate the will of its rider with the feel of the rein, before the most powerful bridle can be of any service.

Animals are so abundant in these countries, that humanity and self-interest are not closely united; therefore I fear it is that the former is here scarcely known. One day, riding in the Pampas with a very respectable "Estanciero," my horse, being tired, lagged behind. The man often shouted to me to spur him. When I remonstrated that it was a pity, for the horse was quite exhausted, he cried out, "Why not?-never mind-spur him -it is my horse." I had then some difficulty in making him comprehend that it was for the horse's sake, and not on his account, that I did not choose to use my spurs. He exclaimed, with a look of great surprise, "Ah, Don Carlos, que cosa!" It was clear that such an idea had never before entered his head.

The Gauchos are well known to be perfect riders. The idea of being thrown, let the horse do what it likes, never enters their head. Their criterion of a good rider is, a man who can manage an untamed colt, or who, if his horse falls, alights on his own feet, or can perform other such exploits. I have heard of a man betting that he would throw his horse down twenty times, and that nineteen times he would not fall himself. I recollect seeing a Gaucho riding a very stubborn horse, which three times successively reared so high as to fall backwards with great violence. The man judged with uncommon coolness the proper moment for slipping off, not an instant before or after the right time; and as soon as the horse got up, the man jumped on his back, and 
at last they started at a gallop. The Gaucho never appears to exert any muscular force. I was one day watching a good rider, as we were galloping along at a rapid pace, and thought to myself, "surely if the horse starts, you appear so careless on your seat, you must fall." At this moment, a male ostrich sprang from its nest right beneath the horse's nose : the young colt bounded on one side like a stag; but as for the man, all that could be said was, that he started and took fright with his horse.

In Chile and Peru more pains are taken with the mouth of the horse than in La Plata, and this is evidently a consequence of the more intricate nature of the country. In Chile a horse is not considered perfectly broken, till he can be brought up standing, in the midst of his full speed, on any particular spot,-for instance, on a cloak thrown on the ground: or, again, he will charge a wall, and rearing, scrape the surface with his hoofs. I have seen an animal bounding with spirit, yet merely reined by a fore-finger and thumb, taken at full gallop across a courtyard, and then made to wheel round the post of a veranda with great speed, but at so equal a distanee, that the rider, with outstretched arm, all the while kept one finger rubbing the post. Then making a demi-volte in the air, with the other arm outstretched in a like manner, he wheeled round, with astonishing force, in an opposite direction.

Such a horse is well broken; and although this at first may appear useless, it is far otherwise. It is only carrying that which is daily necessary into perfection. When a bullock is checked and caught by the lazo, it will sometimes gallop round and round in a circle, and the horse being alarmed at the great strain, if not well broken, will not readily turn like the pivot of a wheel. In consequence many men have been killed; for if the lazo once takes a twist round a man's body, it will in.stantly, from the power of the two opposed animals, almost cut him in twain. On the same principle the races are managed; the course is only two or three hundred yards long, the wish being to have horses that can make a rapid dash. The racehorses are trained not only to stand with their hoofs touching a line, but to draw all four feet together, so as at the first spring to bring into play the full action of the hind-quarters. In Chile 
I was told an anecdote, which I believe was true; and it offers a good illustration of the use of a well-broken animal. A respectable man riding one day met two others, one of whom was mounted on a horse, which he knew to have been stolen from himself. He challenged them; they answered him by drawing their sabres and giving chace. The man, on his good and fleet beast, kept just ahead: as he passed a thick bush he wheeled round it, and brought up his horse to a dead check. The pursuers were obliged to shoot on one side and ahead. Then instantly dashing on, right behind them, he buried his knife in the back of one, wounded the other, recovered his horse from the dying robber, and rode home. For these feats of horsemanship two things are necessary: a most severe bit, like the Mameluke, the power of which, though seldom used, the horse knows full well; and large blunt spurs, that can be applied either as a mere touch, or as an instrument of extreme pain. I conceive that with English spurs, the slightest touch of which pricks the skin, it would be impossible to break in a horse after the South American fashion.

At an estancia near Las Vacas large numbers of mares are weekly slaughtered for the sake of their hides, although worth only five paper dollars, or about half-a-crown apiece. It seems at first strange that it can answer to kill mares for such a trifle; but as it is thought ridiculous in this country ever to break in or ride a mare, they are of no value except for breeding. The only thing for which I ever saw mares used, was to tread out wheat from the ear; for which purpose they were driven round a circular enclosure, where the wheat-sheaves were strewed. The man employed for slaughtering the mares happened to be celebrated for his dexterity with the lazo. Standing at the distance of twelve yards from the mouth of the corral, he has laid a wager that he would catch by the legs every animal, without missing one, as it rushed past him. There was another man who said he would enter the corral on foot, catch a mare, fasten her front legs together, drive her out, throw her down, kill, skin, and stake the hide for drying (which latter is a tedious job); and he engaged that he would perform this whole operation on twenty-two animals in one day. Or he would kill and take the skin off fifty in the same time. This would have been a prodigious task, for it is 
considered a good day's work to skin and stake the hides of fifteen or sixteen animals.

November 26th.-I set out on my return in a direct line for Monte Video. Having heard of some giant's bones at a neighbouring farm-house on the Sarandis, a small stream entering the Rio Negro, I rode there accompanied by my host, and purchased for the value of eighteen pence the head of the Toxodon. When found it was quite perfect; but the boys knocked out some of the teeth with stones, and then set up the head as a mark to throw at. By a most fortunate chance I found a perfect tooth, which exactly fitted one of the sockets in this skull, embedded by itself on the banks of the Rio Tercero, at the distance of about 180 miles from this place. I found remains of this extraordinary animal at two other places, so that it must formerly have been common. I found here, also, some large portions of the armour of a gigantic armadillo-like animal, and part of the great head of a Mylodon. The bones of this head are so fresh, that they contain, according to the analysis by Mr. T. Reeks, seven per cent. of animal matter; and when placed in a spirit-lamp, they burn with a small flame. The number of the remains embedded in the grand estuary deposit which forms the Pampas and covers the granitic rocks of Banda Oriental, must be extraordinarily great. I believe a straight line drawn in any direction through the Pampas would cut through some skeleton or bones. Besides those which I found during my short excursions, I heard of many others, and the origin of such names as "the stream of the animal," "the hill of the giant," is obvious. At other times I heard of the marvellous property of certain rivers, which had the power of changing small bones into large; or, as some maintained, the bones themselves grew. As far as I am aware, not one of these animals perished, as was formerly supposed, in the marshes or muddy river-beds of the present land, but their bones have been exposed by the streams intersecting the subaqueous deposit in which they were originally embedded. We may conclude that the whole area of the Pampas is one wide sepulchre of these extinct gigantic quadrupeds.

* I must express my obligation to Mr. Keane, at whose house I was staying on the Berquelo, and to Mr. Lumb at Buenos Ayres, for without their assistance these valuable remains would never have reached England. 
By the middle of the day, on the 28th, we arrived at Monte Video, having been two days and a half on the road. The country for the whole way was of a very uniform character, some parts being rather more rocky and hilly than near the Plata. Not far from Monte Video we passed through the village of Las Pietras, so named from some large rounded masses of syenite. Its appearance was rather pretty. In this country a few fig-trees round a group of houses, and a site elevated a hundred feet above the general level, ought always to be called picturesque.

During the last six months I have had an opportunity of seeing a little of the character of the inhabitants of these provinces. The Gauchos, or countrymen, are very superior to those who reside in the towns. The Gaucho is invariably most obliging, polite, and hospitable: I did not meet with even one instance of rudeness or inhospitality. He is modest, both respecting himself and country, but at the same time a spirited, bold fellow. On the other hand, many robberies are committed, and there is much bloodshed: the habit of constantly wearing the knife is the chief cause of the latter. It is lamentable to hear how many lives are lost in trifling quarrels. In fighting, each party tries to mark the face of his adversary by slashing his nose or eyes; as is often attested by deep and horrid-looking scars. Robberies are a natural consequence of universal gambling, much drinking, and extreme indolence. At Mercedes I asked two men why they did not work. One gravely said the days were too long; the other that he was too poor. The number of horses and the profusion of food are the destruction of all industry. Moreover, there are so many feast-days; and again, nothing can succeed without it be begun when the moon is on the increase; so that half the month is lost from these two causes,

Police and justice are quite inefficient. If a man who is poor commits murder and is taken, he will be imprisoned, and perhaps even shot; but if he is rich and has friends, he may rely on it no very severe consequence will ensue. It is curious that the most respectable inhabitants of the country invariably assist a murderer to escape: they seem to think that the individual sins against the government, and not against the people. A traveller has no pro- 
tection besides his fire-arms; and the constant habit of carrying them is the main check to more frequent robberies.

The character of the higher and more educated classes who reside in the towns, partakes, but perhaps in a lesser degree, of the good parts of the Gaucho, but is, I fear, stained by many vices of which he is free. Sensuality, mockery of all religion, and the grossest corruption, are far from uncommon. Nearly every public officer can be bribed. The head man in the post-office sold forged government franks. The governor and prime minister openly combined to plunder the state. Justice, where gold came into play, was hardly expected by any one. I knew an Englishman, who went to the Chief Justice (he told me, that not then understanding the ways of the place, he trembled as he entered the room), and said, "Sir, I have come to offer you two hundred (paper) dollars (value about five pounds sterling) if you will arrest before a certain time a man who has cheated me. I know it is against the law, but my lawyer (naming him) recommended me to take this step." The Chief Justice smiled acquiescence, thanked him, and the man before night was safe in prison. With this entire want of principle in many of the leading men, with the country full of ill-paid turbulent officers, the people yet hope that a democratic form of government can succeed!

On first entering society in these countries, two or three features strike one as particularly remarkable. The polite and dignified manners pervading every rank of life, the excellent taste displayed by the women in their dresses, and the equality amongst all ranks. At the Rio Colorado some men who kept the humblest shops used to dine with General Rosas. A son of a major at Bahia Blanca gained his livelihood by making paper cigars, and he wished to accompany me, as guide or servant, to Buenos Ayres, but his father objected on the score of the danger alone. Many officers in the army can neither read nor write, yet all meet in society as equals. In Entre Rios, the Sala consisted of only six representatives. One of them kept a common shop, and evidently was not degraded by the office. All this is what would be expected in a new country; nevertheless the absence of gentlemen by profession appears to an Englishman something strange.

When speaking of these countries, the manner in which they 
have been brought up by their unnatural parent, Spain, should always be borne in mind. On the whole, perhaps, more credit is due for what has been done, than blame for that which may be deficient. It is impossible to doubt but that the extreme liberalism of these countries must ultimately lead to good results. The very general toleration of foreign religions, the regard paid to the means of education, the freedom of the press, the facilities offered to all foreigners, and especially, as I am bound to add, to every one professing the humblest pretensions to science, should be recollected with gratitude by those who have visited Spanish South America.

December 6th. - The Beagle sailed from the Rio Plata, never again to enter its muddy stream. Our course was directed to Port Desire, on the coast of Patagonia. Before proceeding any further, I will here put together a few observations made at sea.

Several times when the ship has been some miles off the mouth of the Plata, and at other times when off the shores of Northern Patagonia, we have been surrounded by insects. One evening, when we were about ten miles from the Bay of San Blas, vast numbers of butterflies, in bands or flocks of countless myriads, extended as far as the eye could range. Even by the aid of a telescope it was not possible to see a space free from butterflies. The seamen cried out "it was snowing butterflies," and such in fact was the appearance. More species than one were present, but the main part belonged to a kind very similar to, but not identical with, the common English Colias edusa. Some moths and hymenoptera accompanied the butterflies; and a fine beetle (Calosoma) flew on board. Other instances are known of this beetle having been caught far out at sea; and this is the more remarkable, as the greater number of the Carabidæ seldom or never take wing. The day had been fine and calm, and the one previous to it equally so, with light and variable airs. Hence we cannot suppose that the insects were blown off the land, but we must conclude that they voluntarily took flight. The great bands of the Colias seem at first to afford an instance like those on record of the migrations of another butterfy, Vanessa cardui ;* * Lyell's Principles of Geology, vol. iii. p. 63. 
but the presence of other insects makes the case distinct, and even less intelligible. Before sunset a strong breeze sprung up from the north, and this must have caused tens of thousands of the butterflies and other insects to have perished.

On another occasion, when seventeen miles off Cape Corrientes, I had a net overboard to catch pelagic animals. Upon drawing' it up, to my surprise I found a considerable number of beetles in it, and although in the open sea, they did not appear much injured by the salt water. I lost some of the specimens, but those which I preserved belonged to the genera Colymbetes, Hydroporus, Hydrobius (two species), Notaphus, Cynucus, Adimonia, and Scarabrus. At first I thought that these insects had been blown from the shore; but upon reflecting that out of the eight species four were aquatic, and two others partly so in their habits, it appeared to me most probable that they were floated into the sea by a small stream which drains a lake near Cape Corrientes. On any supposition it is an interesting circumstance to find live insects swimming in the open ocean seventeen miles from the nearest point of land. 'There are several accounts of insects having been blown off the Patagonian shore. Captain Cook observed it, as did more lately Captain King in the Adventure. The cause probably is due to the want of shelter, both of trees and hills, so that an insect on the wing, with an off-shore breeze, would be very apt to be blown out to sea. The most remarkable instance I have known of an insect being caught far from the land, was that of a large grasshopper (Acrydium), which flew on board, when the Beagle was to windward of the Cape de Verd Islands, and when the nearest point of land, not directly opposed to the trade-wind, was Cape Blanco on the coast of Africa, 370 miles distant.*

On several occasions, when the Beagle has been within the mouth of the Plata, the rigging has been coated with the web of the Gossamer Spider. One day (November 1st, 1832) I paid particular attention to this subject. The weather had been fine and clear, and in the morning the air was full of patches of the flocculent web, as on an autumnal day in England. The ship

* The flies which frequently accompany a ship for some days on its passage from harbour to harbour, wandering from the vessel, are soon lost, and all disappear. 
was sixty miles distant from the land, in the direction of a steady though light breeze. Vast numbers of a small spider, about onetenth of an inch in length, and of a dusky red colour, were attached to the webs. There must have been, I should suppose, some thousands on the ship. The little spider, when first coming in contact with the rigging, was always seated on a single thread, and not on the flocculent mass. This latter seems merely to be produced by the entanglement of the single threads. The spiders were all of one species, but of both sexes, together with young ones. These latter were distinguished by their smaller size and more dusky colour. I will not give the description of this spider, but merely state that it does not appear to me to be included in any of Latreille's genera. The little aëronaut as soon as it arrived on board was very active, running about, sometimes letting itself fall, and then reascending the same thread; sometimes employing itself in making a small and very irregular mesh in the corners between the ropes. It could run with facility on the surface of water. When disturbed it lifted up its front legs, in the attitude of attention. On its first arrival it appeared very thirsty, and with exserted maxillæ drank eagerly of drops of water; this same circumstance has been observed by Strack 1 may it not be in consequence of the little insect having passed through a dry and rarefied atmosphere? Its stock of web seemed inexhaustible. While watching some that were suspended by a single thread, I several times observed that the slightest breath of air bore them away out of sight, in a horizontal line. On another occasion (25th) under similar circumstances, I repeatedly observed the same kind of small spider, either when placed or having crawled on some little eminence, elevate its abdomen, send forth a thread, and then sail away horizontally, but with a rapidity which was quite unaccountable. I thought I could perceive that the spider, before performing the above preparatory steps, connected its legs together with the most delicate threads, but I am not sure whether this observation was correct.

One day, at St. Fé, I had a better opportunity of observing some similar facts. A spider which was about three-tenths of an inch in length, and which in its general appearance resembled a Citigrade (therefore quite different from the gossamer), while standing on the summit of a post, darted forth four or five threads 
from its spinners. These, glittering in the sunshine, might be compared to diverging rays of light; they were not, however, straight, but in undulations like films of silk blown by the wind. They were more than a yard in length, and diverged in an ascending direction from the orifices. The spider then suddenly let go its hold of the post, and was quickly borne out of sight. The day was hot and apparently quite calm; yet under such circumstances, the atmosphere can never be so tranquil as not to affect a vane so delicate as the thread of a spider's web. If during a warm day we look either at the shadow of any object cast on a bank, or over a level plain at a distant landmark, the effect of an ascending current of heated air is almost always evident: such upward currents, it has been remarked, are also shown by the ascent of soap-bubbles, which will not rise in an in-doors room. Hence I think there is not much difficulty in understanding the ascent of the fine lines projected from a spider's spinners, and afterwards of the spider itself; the divergence of the lines has been attempted to be explained, I believe by Mr. Murray, by their similar electrical condition. The circumstance of spiders of the same species, but of different sexes and ages, being found on several occasions at the distance of many leagues from the land, attached in vast numbers to the lines, renders it probable that the habit of sailing through the air is as characteristic of this tribe, as that of diving is of the Argyroneta. We may then reject Latreille's supposition, that the gossamer owes its origin indifferently to the young of several genera of spiders : although, as we have seen, the young of other spiders do possess the power of performing ärial voyages.*

During our different passages south of the Plata, I often towed astern a net made of bunting, and thus caught many curious animals. Of Crustacea there were many strange and undescribed genera. One, which in some respects is allied to the Notopods (or those crabs which have their posterior legs placed almost on their backs, for the purpose of adhering to the under side of rocks), is very remarkable from the structure of its hind pair of legs. The penultimate joint, instead of terminating in a simple claw, ends in three bristle-like appendages of dissimilar lengths-

- Mr. Blackwall, in his Researches in Zoology, has many excellent observations on the habits of spiders. 
the longest equalling that of the entire leg. These claws are very thin, and are serrated with the finest teeth, directed backwards : their curved extremities are flattened, and on this part five most minute cups are placed which seem to act in the same manner as the suckers on the arms of the cuttle-fish. As the animal lives in the open sea, and probably wants a place of rest, I suppose this beautiful and most anomalous structure is adapted to take hold of floating marine animals.

In deep water, far from the land, the number of living creatures is extremely small : south of the latitude $35^{\circ}$, I never succeeded in eatching anything besides some beroe, and a few species of minute entomostracous crustacea. In shoaler water, at the distance of a few miles from the coast, very many kinds of crustacea and some other animals are numerous, but only during the night. Between latitudes $56^{\circ}$ and $57^{\circ}$ south of Cape Horn, the net was put astern several times; it never, however, brought up anything besides a few of two extremely minute species of Entomostraca. Yet whales and seals, petrels and albatross, are exceedingly abundant throughout this part of the ocean. It has always been a mystery to me on what the albatross, which lives far from the shore, can subsist; I presume that, like the condor, it is able to fast long; and that one good feast on the carcass of a putrid whale lasts for a long time. The central and intertropical parts of the Atlantic swarm with Pteropoda, Crustacea, and Radiata, and with their devourers the flying-fish, and again with their devourers the bonitos and albicores; I presume that the numerous lower pelagie animals feed on the Infusoria, which are now known, from the researches of Ehrenberg, to abound in the open ocean: but on what, in the clear blue water, do these Infusoria subsist?

While sailing a little south of the Plata on one very dark night, the sea presented a wonderful and most beautiful spectacle. There was a fresh breeze, and every part of the surface, which during the day is seen as foam, now glowed with a pale light. The vessel drove before her bows two billows of liquid phosphorus, and in her wake she was followed by a milky train. As far as the eye reached, the crest of every wave was bright, and the sky above the horizon, from the reflected glare of these livid flames, was not so utterly obscure as over the vault of the heavens. 
As we proceed further southward the sea is seldom phosphorescent ; and off Cape Horn I do not recollect more than once having seen it so, and then it was far from being brilliant. This circumstance probably has a close connexion with the scarcity of organic beings in that part of the ocean. After the elaborate paper* by Ehrenberg, on the phosphorescence of the sea, it is almost superfluous on my part to make any observations on the subject. I may however add, that the same torn and irregular particles of gelatinous matter, described by Ehrenberg, seem in the southern as well as in the northern hemisphere, to be the common cause of this phenomenon. The particles were so minute as easily to pass through fine gauze; yet many were distinctly visible by the naked eye. The water when placed in a tumbler and agitated, gave out sparks, but a small portion in a watch -glass scarcely ever was luminous. Ehrenberg states that these particles all retain a certain degree of irritability. My observations, some of which were made directly after taking up the water, gave a different result. I may also mention, that having used the net during one night, I allowed it to become partially dry, and having occasion twelve hours afterwards to employ it again, I found the whole surface sparkled as brightly as when first taken out of the water. It does not appear probable in this case, that the particles could have remained so long alive. On one occasion having kept a jelly-fish of the genus Dianæa till it was dead, the water in which it was placed became luminous. When the waves scintillate with bright green sparks, I believe it is generally owing to minute crustacea. But there can be no doubt that very many other pelagic animals, when alive, are phosphorescent.

On two occasions I have observed the sea luminous at considerable depths beneath the surface. Near the mouth of the Plata some circular and oval patches, from two to four yards in diameter, and with defined outlines, shone with a steady but pale light; while the surrounding water only gave out a few sparks. The appearance resembled the reflection of the moon, or some luminous body ; for the edges were sinuous from the undulations of the surface. The ship, which drew thirteen feet water, passed

* An abstract is given in No. IV. of the Magazine of Zoology and Botany. 
over, without disturbing these patches. Therefore we must suppose that some animals were congregated together at a greater depth than the bottom of the vessel.

Near Fernando Noronha the sea gave out light in flashes. The appearance was very similar to that which might be expected from a large fish moving rapidly through a luminous fluid. To this cause the sailors attributed it; at the time, however, I entertained some doubts, on account of the frequency and rapidity of the flashes. I have already remarked that the phenomenon is very much more common in warm than in cold countries; and I have sometimes imagined that a disturbed electrical condition of the atmosphere was most favourable to its production. Certainly $I$ think the sea is most luminous after a few days of more calm weather than ordinary, during which time it has swarmed with various animals, Observing that the water charged with gelatinous particles is in an impure state, and that the luminous appearance in all common cases is produced by the agitation of the fluid in contact with the atmosphere, I am inclined to consider that the phosphorescence is the result of the decomposition of the organic particles, by which process (one is tempted almost to call it a kind of respiration) the ocean becomes purified.

December 23rd.-We arrived at Port Desire, situated in lat. $47^{\circ}$, on the coast of Patagonia. The creek runs for about twenty miles inland, with an irregular width. The Beagle anchored a few miles within the entrance, in front of the ruins of an old Spanish settlement.

The same evening $I$ went on shore. The first landing in any new country is very interesting, and especially when, as in this case, the whole aspect bears the stamp of a marked and individual character. At the height of between two and three hundred feet above some masses of porphyry a wide plain extends, which is truly characteristic of Patagonia. The surface is quite level, and is eomposed of well-rounded shingle mixed with a whitish earth. Here and there scattered tufts of brown wiry grass are supported, and, still more rarely, some low thorny bushes. The weather is dry and pleasant, and the fine blue sky is but seldom obscured. When standing in the middle of one of these desert 
plains and looking towards the interior, the view is generally bounded by the escarpment of another plain, rather higher, but equally level and desolate; and in every other direction the horizon is indistinct from the trembling mirage which seems to rise from the heated surface.

In such a country the fate of the Spanish settlement was soon decided; the dryness of the climate during the greater part of the year, and the occasional hostile attacks of the wandering Indians, compelled the colonists to desert their half-finished buildings. The style, however, in which they were commenced shows the strong and liberal hand of Spain in the old time. The result of all the attempts to colonize this side of America south of $41^{\circ}$, have been miserable. Port Famine expresses by its name the lingering and extreme sufferings of several hundred wretched people, of whom one alone survived to relate their misfortunes. At St. Joseph's Bay, on the coast of Patagonia, a small settlement was made; but during one Sunday the Indians made an attack and massacred the whole party, excepting two men, who remained captives during many years. At the Rio Negro I conversed with one of these men, now in extreme old age.

The zoology of Patagonia is as limited as its Flora.* On the arid plains a few black beetles (Heteromera) might be seen slowly crawling about, and occasionally a lizard darted from side to side. Of birds we have three carrion hawks, and in the valleys a few finches and insect-feeders. An ibis (Theristicus melanops-a species said to be found in central Africa) is not uncommon on the most desert parts : in their stomachs I found grasshoppers, cicadæ, small lizards, and even scorpions. $\dagger$ At one time of the year these birds go in flocks, at another in pairs; their cry is very loud and singular, like the neighing of the guanaco.

* I found here a species of cactus, described by Professor Henslow, under the name of Opuntia Darwinii (Magazine of Zoology and Botany, vol. i. p. 466), which was remarkable by the irritability of the stamens, when I inserted either a piece of stick or the end of my finger in the flower. The segments of the perianth also closed on the pistil, but more slowly than the stamens. Plants of this family, generally considered as tropical, occur in North America (Lewis and Clarke's Travels, p. 221), in the same high latitude as here, namely, in both cases, in $47^{\circ}$.

+ These insects were not uncommon beneath stones. I found one cannibal scorpion quietly devouring another. 
The guanaco, or wild llama, is the characteristic quadruped of the plains of Patagonia ; it is the South American representative of the camel of the East It is an elegant animal in a state of nature, with a long slender neck and fine legs. It is very common over the whole of the temperate parts of the continent, as far south as the islands near Cape Horn. It generally lives in small herds of from half a dozen to thirty in each; but on the banks of the St. Cruz we saw one herd which must have contained at least five hundred.

They are generally wild and extremely wary. Mr. Stokes told me, that he one day saw through a glass a herd of these animals which evidently had been frightened, and were running away at full speed, although their distance was so great that he could not distinguish them with his naked eye. The sportsman frequently receives the first notice of their presence, by hearing from a long distance their peculiar shrill neighing note of alarm. If he then looks attentively, he will probably see the herd standing in a line on the side of some distant hill. On approaching nearer, a few more squeals are given, and off they set at an apparently slow, but really quick canter, along some narrow beaten track to a neighbouring hill. If, however, by chance he abruptly meets a single animal, or several together, they will generally stand motionless and intently gaze at him; then perhaps move on a few yards, turn round, and look again. What is the cause of this difference in their shyness? Do they mistake a man in the distance for their chief enemy the puma? Or does curiosity overcome their timidity? That they are curious is certain; for if a person lies on the ground, and plays strange antics, such as throwing up his feet in the air, they will almost always approach by degrees to reconnoitre him. It was an artifice that was repeatedly practised by our sportsmen with success, and it had moreover the advantage of allowing several shots to be fired, which were all taken as parts of the performance. On the mountains of 'Tierra del Fuego, I have more than once seen a guanaco, on being approached, not only neigh and squeal, but prance and leap about in the most ridiculous manner, apparently in defiance as a challenge. These animals are very easily domesticated, and I have seen some thus kept in northern Patagonia near a house, though not under any restraint. They are in this state very 
bold, and readily attack a man by striking him from behind with both knees. It is asserted that the motive for these attacks is jealousy on account of their females. The wild guanacos, however, have no idea of defence; even a single dog will secure one of these large animals, till the huntsman can come up. In many of their habits they are like sheep in a flock. Thus when they see men approaching in several directions on horseback, they soon become bewildered, and know not which way to run. This greatly facilitates the Indian method of hunting, for they are thus easily driven to a central point, and are encompassed.

The guanacos readily take to the water: several times at Port Valdes they were seen swimming from island to island. Byron, in his voyage, says he saw them drinking salt water. Some of our officers likewise saw a herd apparently drinking the briny fluid from a salina near Cape Blanco. I imagine in several parts of the country, if they do not drink salt water, they drink none at all. In the middle of the day they frequently roll in the dust, in saucer-shaped hollows. The males fight together; two one day passed quite close to me, squealing and trying to bite each other; and several were shot with their hides deeply scored. Herds sometimes appear to set out on exploring parties: at Bahia Blanca, where, within thirty miles of the coast, these animals are extremely unfrequent, I one day saw the tracks of thirty or forty, which had come in a direct line to a muddy saltwater creek. They then must have perceived that they were approaching the sea, for they had wheeled with the regularity of cavalry, and had returned back in as straight a line as they had advanced. The guanacos have one singular habit, which is to me quite inexplicable; namely, that on successive days they drop their dung in the same defined heap. I saw one of these heaps which was eight feet in diameter, and was composed of a large quantity. This habit, according to M. A. d'Orbigny, is common to all the species of the genus; it is very useful to the Peruvian Indians, who use the dung for fuel, and are thus saved the trouble of collecting it.

The guanacos appear to have favourite spots for lying down to die. On the banks of the St. Cruz, in certain circunscribed spaces, which were generally bushy and all near the river, the ground was actually white with bones. On one such spot I 
counted between ten and twenty heads. I particularly examired the bones; they did not appear, as some scattered ones which I had seen, gnawed or broken, as if dragged together by beasts of prey. The animals in most cases must have crawled, before dying, beneath and amongst the bushes. Mr. Bynoe informs me that during a former voyage he observed the same circumstance on the banks of the Rio Gallegos. I do not at all understand the reason of this, but I may observe, that the wounded guanacos at the St. Cruz invariably walked towards the river. At St. Jago in the Cape de Verd islands, I remember having seen in a ravine a retired corner covered with bones of the goat; we at the time exclaimed that it was the burial-ground of all the goats in the island. I mention these trifling circumstances, because in certain cases they might explain the occurrence of a number of uninjured bones in a cave, or buried under alluvial accumulations; and likewise the cause why certain animals are more commonly embedded than others in sedimentary deposits.

One day the yawl was sent under the command of Mr. Chaffers with three days' provisions to survey the upper part of the harbour. In the morning we searched for some watering-places mentioned in an old Spanish chart. We found one creek, at the head of which there was a trickling rill (the first we had seen) of brackish water. Here the tide compelled us to wait several hours; and in the interval I walked some miles into the interior. The plain as usual consisted of gravel, mingied with soil resembling chalk in appearance, but very different from it in nature. From the softness of these materials it was worn into many gulleys. There was not a tree, and, excepting the guanaco, which stood on the hill-top a watchful sentinel over its herd, scarcely an animal or a bird. All was stillness and desolation. Yet in passing over these scenes, without one bright object near, an illdefined but strong sense of pleasure is vividly excited. One asked how many ages the plain had thus lasted, and how many more it was doomed thus to continue.

None can reply-all seems eternal now.

The wilderness has a mysterious tongue,

Which teaches awful doubt.*

* Shelley, Lines on M. Blanc. 
In the evening we sailed a few miles further up, and then pitched the tents for the night. By the middle of the next day the yawl was aground, and from the shoalness of the water could not proceed any higher. The water being found partly fresh, Mr. Chaffers took the dingey and went up two or three miles further, where she also grounded, but in a fresh-water river. The water was muddy, and though the stream was most insignificant in size, it would be difficult to account for its origin, except from the melting snow on the Cordillera. At the spot where we bivouacked, we were surrounded by bold cliffs and steep pinnacles of porphyry. I do not think I ever saw a spot which appeared more secluded from the rest of the world, than this rocky crevice in the wicle plain.

The second day after our return to the anchorage, a party of officers and myself weut to ransack an old Indian grave, which I had found on the summit of a neighbouring hill. Tro immense stones, each probably weighing at least a couple of tons, had been placed in front of a ledge of rock about six feet high. At the bottom of the grave on the hard rock there was a layer of earth about a foot deep, which must have been brought up from the plain below. Above it a pavement of flat stones was placed, on which others were piled, so as to fill up the space between the ledge and the two great blocks. To complete the grave, the Indians had contrived to detach from the ledge a huge fragment, and to throw it over the pile so as to rest on the two blocks. We undermined the grave on both sides, but could not find any relics, or even bones. The latter probably had decayed long since (in which case the grave must have been of extreme antiquity), for I found in another place some smaller heaps, beneath which a very few crumbling fragments could yet be distinguished as having belonged to a man. Falconer states, that where an Indian dies he is buried, but that subsequently his bones are carefully taken up and carried, let the distance be ever so great, to be deposited near the sea-coast. This custom, I think, may be accounted for by recollecting, that before the introduction of horses, these Indians must have led nearly the same life as the Fuegians now do, and therefore generally have resided in the neighbourhood of the sea. The common prejudice of lying where one's ancestors have lain, would make the now 
roaming Indians bring the less perishable part of their dead to their ancient burial-ground on the coast.

January 9th, 1834.-Before it was dark the Beagle anchored in the fine spacious harbour of Port St. Julian, situated about one hundred and ten miles to the south of Port Desire. We remained here eight days. The country is nearly similar to that of Port Desire, but perhaps rather more sterile. One day a party accompanied Captain Fitz Roy on a long walk round the head of the harbour. We were eleven hours without tasting any water, and some of the party were quite exhausted. From the summit of a hill (since well named Thirsty Hill) a fine lake was spied, and two of the party proceeded with concerted signals to show whether it was fresh water. What was our disappointment to find a snow-white expanse of salt, crystallized in great cubes! We attributed our extreme thirst to the dryness of the atmosphere; but whatever the cause might be, we were exceedingly glad late in the evening to get back to the boats. Although we could nowhere find, during our whole visit, a single drop of fresh water, yet some must exist; for by an odd chance I found on the surface of the salt water, near the head of the bay, a Colymbetes not quite dead, which must have lived in some not far distant pool. Three other insects (a Cincindela, like hybrida, a Cymindis, and a Harpalus, which all live on muddy flats occasionally overflowed by the sea), and one other found dead on the plain, complete the list of the beetles. A good-sized fly (Tabanus) was extremely numerous, and tormented us by its painful bite. The common horsefly, which is so troublesome in the shady lanes of England, belongs to this same genus. We here have the puzzle that so frequently occurs in the case of musquitoes-on the blood of what animals do these insects commonly feed? The guanaco is nearly the only warm-blooded quadruped, and it is found in quite inconsiderable numbers compared with the multitude of flies.

The geology of Patagonia is interesting. Differently from Europe, where the tertiary formations appear to have accumulated in bays, here along hundreds of miles of coast we have one great deposit, including many tertiary shells, all apparently extinct. The most common shell is a massive gigantic oyster, 
sometimes even a foot in diameter. These beds are covered by others of a peculiar soft white stone, including much gypsum, and resembling chalk, but really of a pumiceous nature. It is highly remarkable, from being composed, to at least onetenth part of its bulk, of Infusoria: Professor Ehrenberg has already ascertained in it thirty oceanic forms. This bed extends for 500 miles along the coast, and probably for a considerably greater distance. At Port St. Julian its thickness is more than 800 feet! These white beds are everywhere capped by a mass of gravel, forming probably one of the largest beds of shingle in the world : it certainly extends from near the Rio Colorado to between 600 and 700 nautical miles southward; at Santa Cruz (a river a little south of St. Julian), it reaches to the foot of the Cordillera; half way up the river, its thickness is more than 200 feet; it probably everywhere extends to this great chain, whence the well-rounded pebbles of porphyry have been derived: we may consider its average breadth as 200 miles, and its average thickness as about 50 feet. If this great bed of pebbles, without including the mud necessarily derived from their attrition, was piled into a mound, it would form a great mountain chain! When we consider that all these pebbles, countless as the grains of sand in the desert, have been derived from the slow falling of masses of rock on the old coast-lines and banks of rivers; and that these fragments have been dashed into smaller pieces, and that each of them has since been slowly rolled, rounded, and far transported, the mind is stupified in thinking over the long, absolutely necessary, lapse of years. Yet all this gravel has been transported, and probably rounded, subsequently to the deposition of the white beds, and long subsequently to the underlying beds with the tertiary shells.

Everything in this southern continent has been effected on a grand scale: the land, from the Rio Plata to Tierra del Fuego, a distance of 1200 miles, has been raised in mass (and in Patagonia to a height of between 300 and 400 feet), within the period of the now existing sea-shells. The old and weathered shells left on the surface of the upraised plain still partially retain their colours. The uprising movement has been interrupted by at least eight long periods of rest, during which the sea ate deeply back into the land, forming at successive levels the long lines of 
cliffs or escarpments, which separate the different plains as they rise like steps one behind the other. The elevatory movement, and the eating-back power of the sea during the periods of rest, have been equable over long lines of coast; for I was astonished to find that the step-like plains stand at nearly corresponding heights at far distant points. The lowest plain is 90 feet high; and the highest, which I ascended near the coast, is 950 feet; and of this, only relics are left in the form of flat gravelcapped hills. The upper plain of S. Cruz slopes up to a height of 3000 feet at the foot of the Cordillera. I have said that within the period of existing sea-shells Patagonia has been upraised 300 to 400 feet: I may add, that within the period when icebergs transported boulders over the upper plain of Santa Cruz, the elevation has been at least 1500 feet. Nor has Patagonia been affected only by upward movements : the extinct tertiary shells from Port St. Julian and Santa Cruz cannot have lived, according to Professor E. Forbes, in a greater depth of water than from 40 to 250 feet; but they are now covered with sea-deposited strata from 800 to 1000 feet in thickness : hence the bed of the sea, on which these shells once lived, must have sunk downwards several hundred feet, to allow of the accumulation of the superincumbent strata. What a history of geological changes does the simply-constructed coast of Patagonia reveal!

At Port St. Julian*, in some red mud capping the gravel on the 90-feet plain, I found half the skeleton of the Macrauchenia Patachonica, a remarkable quadruped, full as large as a camel. It belongs to the same division of the Pachydermata with the rhinoceros, tapir, and palæotherium; but in the structure of the bones of its long neck it shows a clear relation to the camel, or rather to the guanaco and llama. From recent sea-shells being found on two of the higher step-formed plains, which must have been modelled and upraised before the mud was deposited in which the Macrauchenia was intombed, it is certain that this curious quadruped lived long after the sea was inhabited by its

* I have lately heard that Capt. Sulivan, R.N., has found numerous fossil bones, embedded in regular strata, on the banks of the R. Gallegos, in lat. $51^{\circ} 4^{\prime}$. Some of the bones are large; others are small, and appear to have belonged to an armadillo. This is a most interesting and important discovery. 
present shells. I was at first much surprised how a large quadruped could so lately have subsisted, in lat. $49^{\circ} 15^{\prime}$, on these wretched gravel plains with their stunted vegetation; but the relationship of the Macrauchenia to the guanaco, now an inhabitant of the most sterile parts, partly explains this difficulty.

The relationship, though distant, between the Macrauchenia and the Guanaco, between the Toxodon and the Capybara,the closer relationship between the many extinct Edentata and the living sloths, ant-eaters, and armadillos, now so eminently characteristic of South American zoology,-and the still closer relationship between the fossil and living species of Ctenomys and Hydrochærus, are most interesting facts. This relationship is shown wonderfully - as wonderfully as between the fossil and extinct Marsupial animals of Australia-by the great collection lately brought to Europe from the caves of Brazil by MM. Lund and Clausen. In this collection there are extinct species of all the thirty-two genera, excepting four, of the terrestrial quadrupeds now inhabiting the provinces in which the caves occur; and the extinct species are much more numerous than those now living: there are fossil ant-eaters, armadillos, tapirs, peccaries, guanacos, opossums, and numerous South American gnawers and monkeys, and other animals. This wonderful relationship in the same continent between the dead and the living, will, I do not doubt, hereafter throw more light on the appearance of organic beings on our earth, and their disappearance from it, than any other class of facts.

It is impossible to reflect on the changed state of the American continent without the deepest astonishment. Formerly it must have swarmed with great monsters: now we find mere pigmies, compared with the antecedent, allied races. If Buffon had known of the gigantic sloth and armadillo-like animals, and of the lost Pachydermata, he might have said with a greater semblance of truth that the creative force in America had lost its power, rather than that it had never possessed great vigour. The greater number, if not all, of these extinct quadrupeds lived at a late period, and were the contemporaries of most of the existing sea-shells. Since they lived, no very great change in the form of the land can have taken place. What, then, has exterminated so many species and whole genera? The mind at first is irre- 
sistibly hurried into the belief of some great catastrophe; but thus to destroy animals, both large and small, in Southern Patagonia, in Brazil, on the Cordillera of Peru, in North America up to Behring's Straits, we must shake the entire framework of the globe. An examination, moreover, of the geology of La Plata and Patagonia, leads to the belief that all the features of the land result from slow and gradual changes. It appears from the character of the fossils in Europe, Asia, Australia, and in North and South America, that those conditions which favour the life of the larger quadrupeds were lately co-extensive with the world: what those conditions were, no one has yet even conjectured. It could hardly have been a change of temperature, which at about the same time destroyed the inhabitants of tropical, temperate, and arctic latitudes on both sides of the globe. In North America we positively know from Mr. Lyell, that the large quadrupeds lived subsequently to that period, when boulders were brought into latitudes at which icebergs now never arrive: from conclusive but indirect reasons we may feel sure, that in the southern hemisphere the Macrauchenia, also, lived long subsequently to the ice-transporting boulder-period. Did man, after his first inroad into South America, destroy, as has been suggested, the unwieldy Megatherium and the other Edentata? We must at least look to some other cause for the destruction of the little tucutuco at Bahia Blanca, and of the many fossil mice and other small quadrupeds in Brazil. No one will imagine that a drought, even far severer than those which cause such losses in the provinces of La Plata, could destroy every individual of every species from Southern Patagonia to Behring's Straits. What shall we say of the extinction of the horse? Did those plains fail of pasture, which have since been overrun by thousands and hundreds of thousands of the descendants of the stock introduced by the Spaniards? Have the subsequently introduced species consumed the food of the great antecedent races? Can we believe that the Capybara has taken the food of the Toxodon, the Guanaco of the Macrauchenia, the existing small Edentata of their numerous gigantic prototypes? Certainly, no fact in the long history of the world is so startling as the wide and repeated exterminations of its inhabitants.

Nevertheless, if we consider the subject under another point of 
view, it will appear less perplexing. We do not steadily bear in mind, how profoundly ignorant we are of the conditions of exist-. ence of every animal; nor do we always remember, that some check is constantly preventing the too rapid increase of every organized being left in a state of nature. The supply of food, on an average, remains constant; yet the tendency in every animal to increase by propagation is geometrical ; and its surprising effects have nowhere been more astonishingly shown, than in the case of the European animals run wild during the last few centuries in America. Every animal in a state of nature regularly breeds; yet in a species long established, any great increase in numbers is obviously impossible, and must be checked by some means. We are, nevertheless, seldom able with certainty to tell in any given species, at what period of life, or at what period of the year, or whether only at long intervals, the check falls; or, again, what is the precise nature of the check. Hence probably it is, that we feel so little surprise at one, of two species closely allied in habits, being rare and the other abundant in the same district; or, again, that one should be abundant in one district, and another, filling the same place in the economy of nature, should be abundant in a neighbouring district, differing very little in its conditions. If asked how this is, one immediately replies that it is determined by some slight difference in climate, food, or the number of enemies : yet how rarely, if ever, we can point out the precise cause and manner of action of the check! We are, therefore, driven to the conclusion, that causes generally quite inappreciable by us, determine whether a given species shall be abundant or scanty in numbers.

In the cases where we can trace the extinction of a species through man, either wholly or in one limited district, we know that it becomes rarer and rarer, and is then lost: it would be difficult to point out any just distinction* between a species destroyed by man or by the increase of its natural enemies. The evidence of rarity preceding extinction, is more striking in the successive tertiary strata, as remarked by several able observers; it has often been found that a shell very common in a tertiary stratum is now most rare, and has even long been thought to be

* See the excellent remarks on this subject by Mr. Lyell, in his Principles of Geology. 
extinct. If then, as appears probable, species first become rare and then extinct-if the too rapid increase of every species, even the most favoured, is steadily checked, as we must admit, though how and when it is hard to say-and if we see, without the smallest surprise, though unable to assign the precise reason, one species abundant and another closely-allied species rare in the same district-why should we feel such great astonishment at the rarity being carried a step further to extinction? An action going on, on every side of us, and yet barely appreciable, might surely be carried a little further, without exciting our observation. Who would feel any great surprise at hearing that the Megalonyx was formerly rare compared with the Megatherium, or that one of the fossil monkeys was few in number compared with one of the now living monkeys? and yet in this comparative rarity, we should have the plainest evidence of less favourable conditions for their existence. To admit that species generally become rare before they become extinct-to feel no surprise at the comparative rarity of one species with another, and yet to call in some extraordinary agent and to marvel greatly when a species ceases to exist, appears to me much the same as to admit that sickness in the individual is the prelude to death-to feel no surprise at sickness-but when the sick man dies, to wonder, and to believe that he died through violence. 


\section{MR. MURRAY'S LIST OF WORKS.}

\section{(Continued.)}

XIII.

CROKER'S BOSWELL'S LIFE OF JOHNSON, including the Toun to the Hebrides. A New Edition, entirely revised. One Volume. Royal 8vo.

XIV.

CRABBE'S POETICAL WORKS; with a LIFE, by HIS SON. 'A Nero Edition. One Volume. Royal 8vo.

$$
\text { Xv. }
$$

ILLUSTRATED EDITION of the WORKS of HORACE; with an Original Life. By Rev. H. H. MILMAN. Views, Vignettes, Coloured Borders, \&c. Crown 8vo.

XVI.

SCROPE'S DAYS OF DEER-STALKING; with some Account of the Red Deer, Scottish Legends, \&c. Third.Edition. Woodcuts, by LANDseser and WiLkIE. Crown 8vo.

XVII.

LYELL'S PRINCIPLES OF GEOLOGY; or, the Modern Changes of the Earth and its Inhabitants considered as illustrative of Geology. Seventh Edition, entirely revised. Woodcuts. One Volume, 8vo.

\section{XVIII.}

FAMILY ARABIAN NIGHTS. With Explanatory Notes. By E.W. LANE. With 600 Woodcuts by Harver. 3 vols. Post 8 vo.

\section{XIX.}

PROGRESS OF THE NATION, in its Social and Economical Relations, from the beginning of the Nineteenth Century to the Present Time. By G. R. PORTER, F.R.S. New Edition, revised. One Volume, 8va.

xx.

RANKE'S POPES OF ROME, during the Sixteenth and Seventeenth Centuries. Translated by SARAH AUSTIN. Third Edition. 2 vols. 8vo.

$$
\text { xxr. }
$$

PRACTICAL SURVEYING, Plan Drawing, and Sketching Ground without Instruments. By G.D. BURR, Royal Military College, Sandhurst. Nevo Edition, entirely revised. Post 8vo.

\section{XXII.}

STORIES FOR CHILDREN: selected from the HISTORY of ENGLAND, from the Conquest to the Revolution. Fourteenth Edition. With 24 Woodcuts. Square $16 \mathrm{mo}$.

\section{XXIII.}

PROGRESSIVE GEOGRAPHY FOR CHILDREN. By the Author of "Stories for ChuDden." Fourth Edition, revised. $18 \mathrm{mo}$.

XXIV.

REJECTED ADDRESSES. By HORACE and JAMES SMITH. Twentyfirst Edition. Fcap. 8vo. 
FRENCH IN ALGIERS. BRACEBRIDGE HALL DARWIN'S NATURALIST'S VOYAGE. FALL OF THE JESUITS. LORD MAHON'S LIFE OF CONDÉ. BORROW'S GYPSIES IN SPAIN. MELVILLE'S TYPEE AND TOBY. LIVONIAN TALES. MEMOIRS OF A MISSIONARY. SALE'S BRIGADE IN AFGHANISTAN. LETTERS FROM MADRAS. WILD SPORTS IN THE HIGHLANDS. HEAD'S ROUGH NOTES.

Works in Preparation.

SPAIN AND THE SPANIARDS.

BY RICHARD FORD, ESQ.

TWO SIEGES OF VIENNA BY THE TURKS. BY THE EARL OF ELLESMERE.

\section{TALES OF A TRAVELLER.}

BY WASHINGTON IRVING.

\section{STORY OF THE BATTLE OF WATERLOO.} BY REV. G. R. GLEIG. 